\title{
Evaluating Post-Fire Plantation Restoration in a Mixed Conifer Forest in the Sierra Nevada
}

Iris C. Allen

West Virginia University, iris.allen@mail.wvu.edu

Follow this and additional works at: https://researchrepository.wvu.edu/etd

Part of the Forest Management Commons

\section{Recommended Citation}

Allen, Iris C., "Evaluating Post-Fire Plantation Restoration in a Mixed Conifer Forest in the Sierra Nevada" (2019). Graduate Theses, Dissertations, and Problem Reports. 4091.

https://researchrepository.wvu.edu/etd/4091

This Thesis is protected by copyright and/or related rights. It has been brought to you by the The Research Repository @ WVU with permission from the rights-holder(s). You are free to use this Thesis in any way that is permitted by the copyright and related rights legislation that applies to your use. For other uses you must obtain permission from the rights-holder(s) directly, unless additional rights are indicated by a Creative Commons license in the record and/ or on the work itself. This Thesis has been accepted for inclusion in WVU Graduate Theses, Dissertations, and Problem Reports collection by an authorized administrator of The Research Repository @ WVU. For more information, please contact researchrepository@mail.wvu.edu. 
Evaluating Post-Fire Plantation Restoration in a Mixed Conifer Forest in the Sierra Nevada

Iris Allen

Thesis submitted

to the Davis College of Agriculture, Natural Resources, and Design

at West Virginia University

in partial fulfillment of the requirements for the degree of

Masters of Science in

Forest Resources Management

Sophan Chhin, Ph.D., Chair

Kirsten Stephan, Ph.D.

Jamie Schuler, Ph.D.

Division of Forestry and Natural Resources

Morgantown, West Virginia

2019

Keywords: forest ecology, fire ecology, plantation, Sierra Nevada

Copyright 2019: Iris Allen 


\begin{abstract}
Evaluating Post-Fire Plantation Restoration in a Mixed Conifer Forest in the Sierra Nevada
\end{abstract}

\author{
Iris Allen
}

Forests in the western United States have experienced a shift from historical disturbance regimes in the past century. Many of these changes were induced by European settlers logging the forests and suppressing fires. In the past, the dry mixed conifer forests of California's Sierra Nevada mountains experience frequent, low to mixed severity fires. This fire regime helped maintain a heterogeneous landscape comprised of groups of trees and openings. However, due to fire suppression and high grading logging, forest structure has changed; there are less openings and more small, fire-intolerant trees that can carry a fire into the forests crown. The new fire regimes resulting from this change in structure are large, high severity fires that kill a majority of the overstory trees. These novel regimes require novel approaches to regenerate the forest as they are not adapted to large, high severity fires. The United States Forest Service (USFS) will often plant trees after fires to aid with reforestation after large wildfires. A new technique being testing is clustering the trees into groups of two to four, instead of the traditionally evenly spaced plantations.

To evaluate these plantations, I compared growth and development in several post fire plantations and natural regenerating stands in the Eldorado National Forest in the north-central Sierra Nevada Mountains. I tested for growth and ecological differences between clustered and evenly spaced plantations, some with pre-commercial thinning (PCT) and some without, as well as comparing them to stands of naturally regenerating trees using mixed effects models. I compared diameter and height growth, along with tree density, shrub size, and understory species diversity. My results suggest that clustered plantations provide a slight facilitative effect when compared to the evenly spaced plantations. I also found high variability in tree stocking, highlighting the intense shrub competition these young plantations face.

I also forecasted growth and fire behavior 100 years into the future using the Forest Vegetation Simulation (FVS) and its Fire and Fuels Extension (FFE). In these simulations I tested combinations of different fuels treatments (mastication only, mastication with prescribed burning, and no fuels treatments) with different overstory thinning intensities (residual densities of 370SDI (stand density index), 495SDI, 618SDI (TPH), and no overstory thinning) on stand growth and potential fire behavior using three way analysis of variance. I compared growth and crowning index at the end of the simulation and the simulation age when the flame length, basal area mortality, and fire type reached low severity between fuel treatment, thinning intensity, and original management of stands (plantation with PCT, plantation without PCT, and natural regenerating stands). I found an overall pattern of decreasing crown fire occurrence and fire induced mortality across all simulations due to increasing canopy base height and decreasing canopy bulk density. Mastication with prescribed burning was the most effective treatment for quickly reducing fire behavior by consuming surface fuels, thus drastically lowing flame length. My results highlight the different stressor that post fire plantations experience and how different silvicultrual treatments interact with stand development over time to reduce fire risk. They also demonstrate the importance of treating stands early and the effectiveness of surface fuel treatments. 


\section{Acknowledgements}

Thank you to my advisor Dr. Steve Chhin for guidance during my three years of working for him. His advice, patience, and thoughtfulness helped keep me from getting too overwhelmed by graduate school. Thank you to my project's Co-PI, Dr. Jianwei Zhang and the United States Forest Service for providing funding. Dr. Zhang has also dedicated a lot of his time and resources into making this project successful. The other members of my graduate committee, Dr. Kirsten Stephan and Dr. Jamie Schuler, also deserve thanks for providing helpful feedback and project assistance.

A big thank you to Natalie Pawlikowski for assisting me with building and calibrating my FVS simulations and providing very constructive edits to my thesis. Thank you to Dr. Michael Premer, Mukti Subedi, and Dr. James McGraw for providing me with guidance in study design and statistical analysis. There is no way this project could have been completed without help in the field from Stephi Dickinson, Kaelyn Finley, Mukti Subedi, Simeon Spottswood, and Clint Albright. Thank you for dealing with hot weather and steep slopes and for all being wonder field partners. Thank you to the staff at the Amador ranger station of the Eldorado National Forest for providing housing and general assistance during my two field seasons.

Lastly, thank you to my many mentors during my scientific career, especially Dr. Brian Smithers. Thank you for inspiring my love of field work and forest ecology, challenging me to become a better scientist, showing me how to be a good leader, and the countless letters of recommendation. 


\section{Table of Contents}

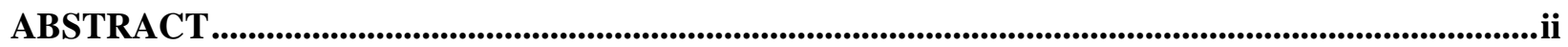

Acknowledgements ...................................................................................................................................................ii

List of Tables ................................................................................................................................ vi

List of Figures........................................................................................................................................................vii

Chapter 1: Fire Management in Montane Forests of the Northwestern United States and California

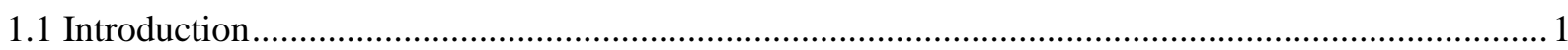

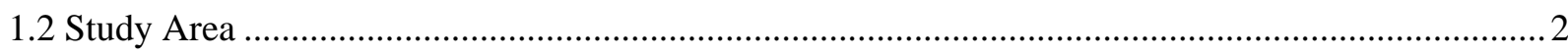

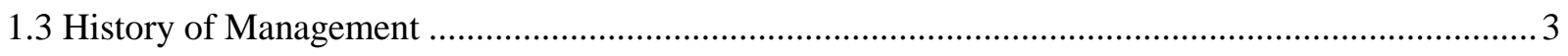

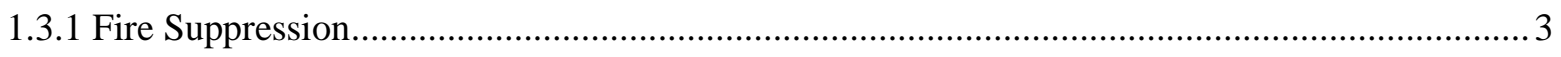

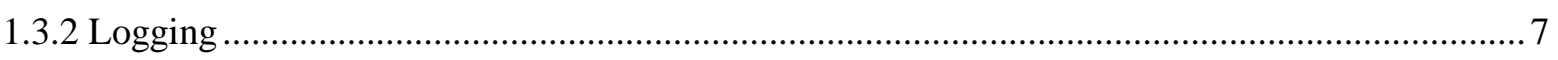

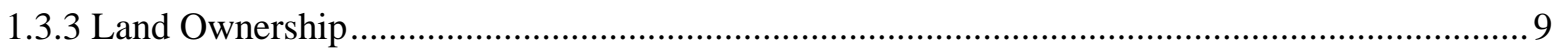

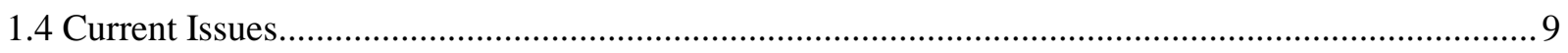

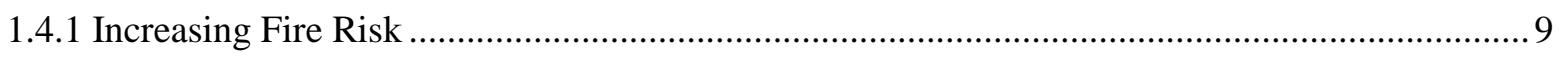

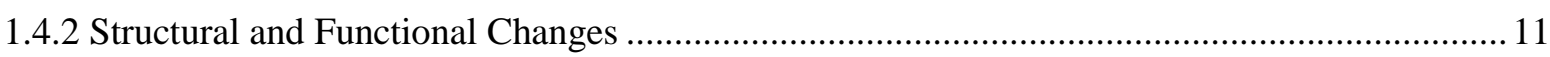

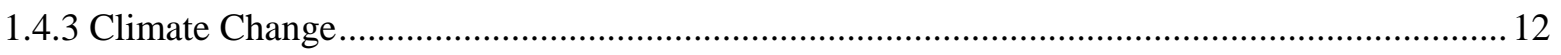

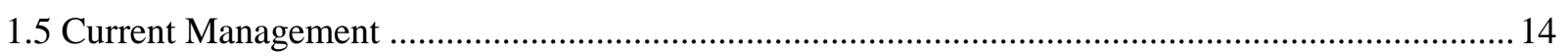

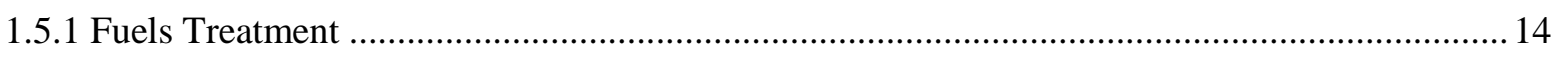

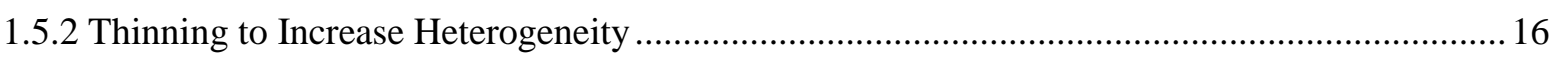

1.5.3 Use of Plantations after a High-Severity Fire .................................................................. 17

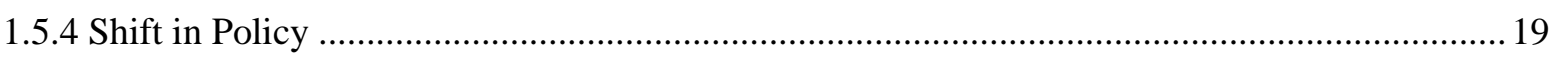

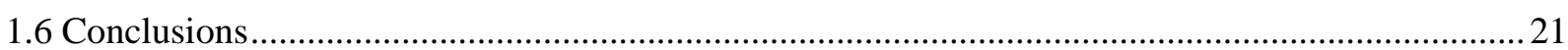

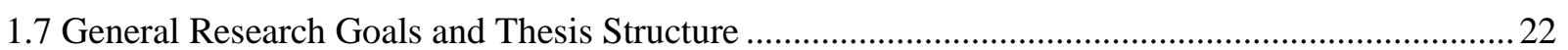

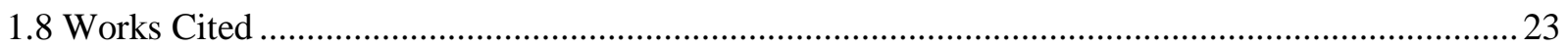

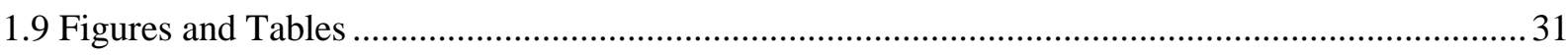

Chapter 2: Comparing past growth and ecology between two plantation arrangements and natural regenerating stands after a high severity fire .....................................................................................................34

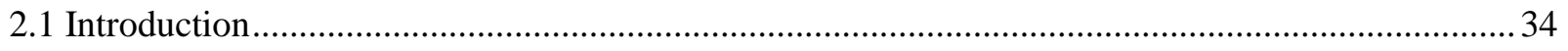

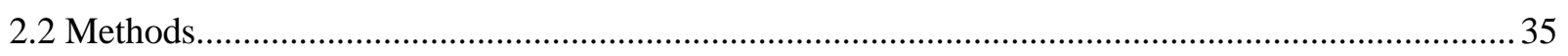

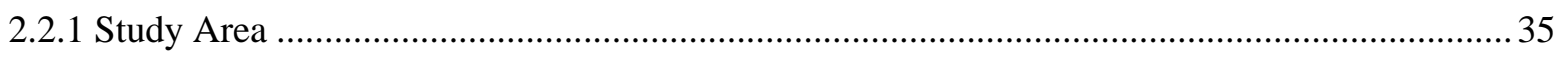

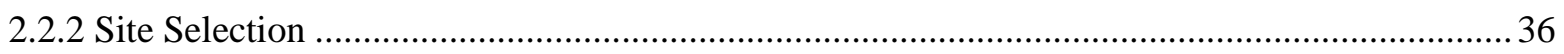

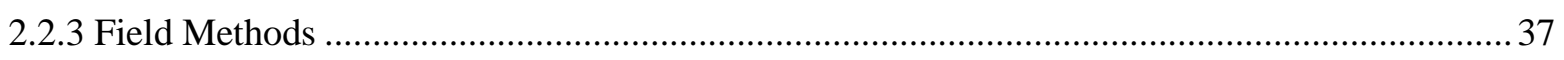

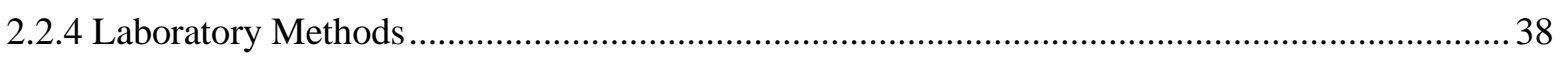

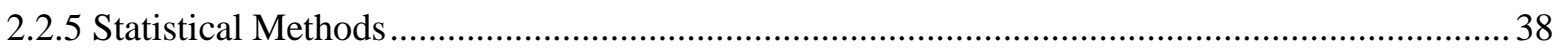




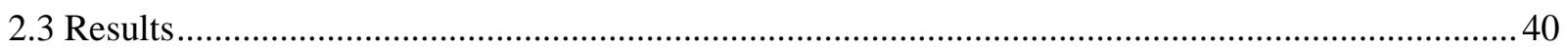

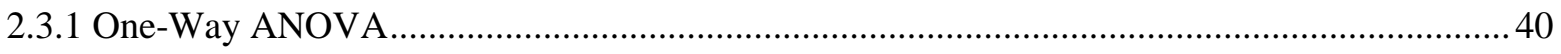

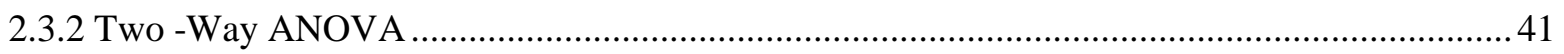

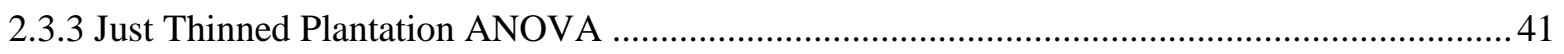

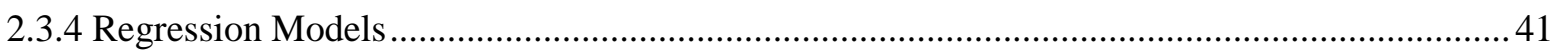

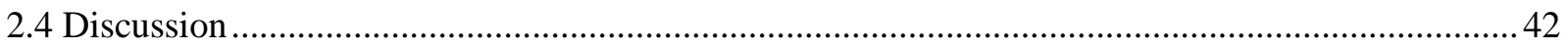

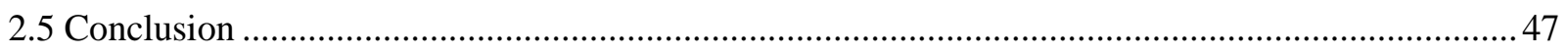

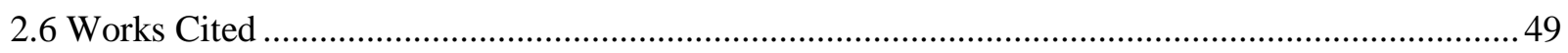

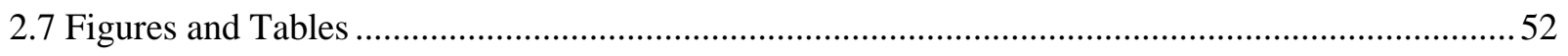

Chapter 3: Modeling future stand development and fire risk of young, post fire plantations under different thinning and fuel treatments using FVS-FFE..........................................................................64

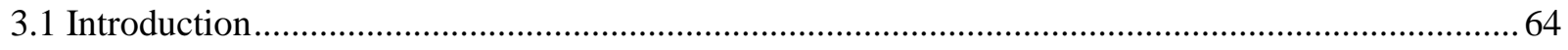

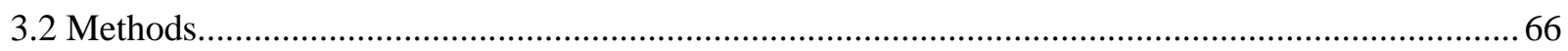

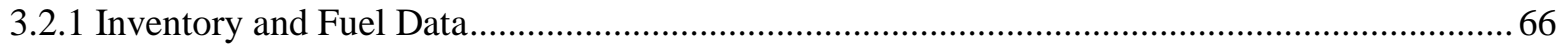

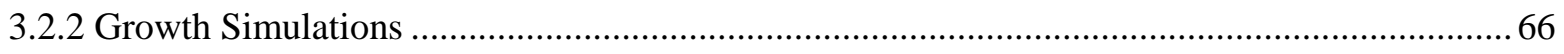

3.2.3 Fuel model selection and fuel characteristics..................................................................... 68

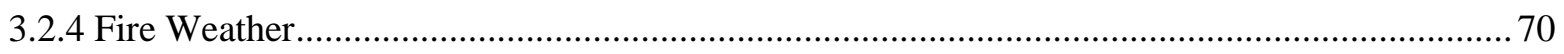

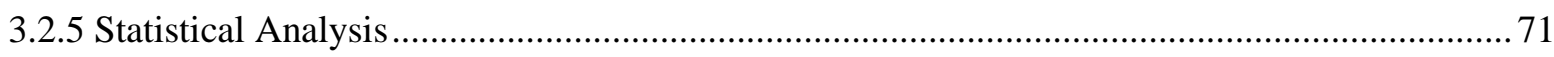

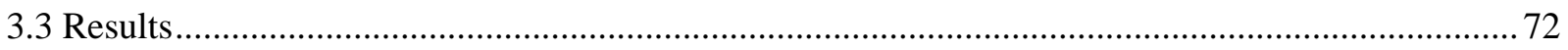

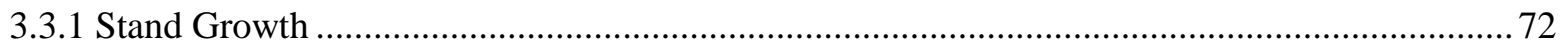

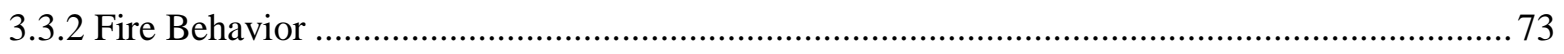

3.3.3 General Fire Behavior and Stand Structure Patterns......................................................... 75

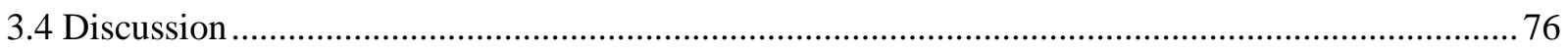

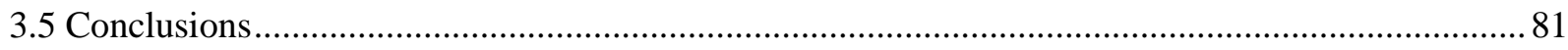

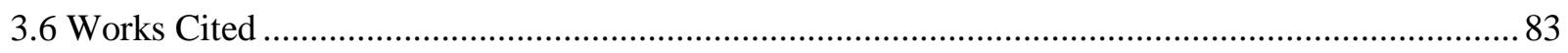

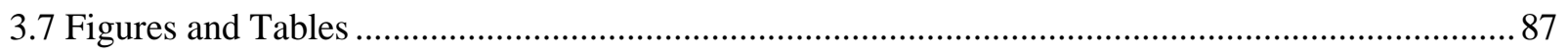

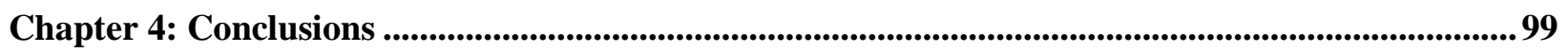




\section{List of Tables}

\section{Chapter 2.}

Table 1. Characteristics of sampled stands. Slope, elevation, and aspect are averaged across the plots per stand

Table 2. Species composition of the sampled stands in trees per hectare. $\mathrm{ABCO}=$ Abies concolor, $\mathrm{ABMA}$ $=$ Abies magnifica, $\mathrm{CADE}=$ Calocedrus decurrens, $\mathrm{PIJE}=$ Pinus jeffreyi, $\mathrm{PIPO}=$ Pinus ponderosa, PILA $=$ Pinus lambertiana, $\mathrm{PSME}=$ Pseudotusga menziesii.

Table 3. Results from one way ANOVA among the five overall treatment categories (TRT). * indicates significance at 0.1 level, $* *$ indicates significance at 0.05 level for TRT. Regen/ Hec $=$ trees below $1.37 \mathrm{~m}$ per hectare; $\mathrm{TPH}=$ trees per hectare; $\mathrm{BAI}=$ basal area increment

Table 4. Results from two-way ANOVA testing planting arrangement $(\mathrm{P})$ and thinning $(\mathrm{T})$ among the plantations $*$ indicates significance at 0.1 level, $* *$ indicates significance at 0.05 level for fixed effects.

Table 5. Results from one way ANOVA on just thinned plantations comparing planting arrangements. * indicates significance at 0.1 level, for fixed effects

Table 6. Final selection for linear regression models predicting growth in mixed conifer plantations and natural regenerating stands. Rich $=$ species richness, freq YP $=$ the frequency of yellow pines, regencount $=$ density of regeneration (trees under $1.37 \mathrm{~m}$ ), TPH $=$ trees per hectare, TrtAY = dummy variable for clustered, thinned plantations, TrtBN = dummy variable for evenly spaced, unthinned plantations, TrtBY = dummy variable for evenly spaced, thinned plantations, TrtNRG

$=$ dummy variable for natural regenerating stands. .55

Table 7. Final selection for linear regression models predicting growth in plantations. Shrub cover $=\%$ of plot covered with shrubs, rich $=$ species richness, $\mathrm{TPH}=$ trees per hectare, freqYP $=$ the frequency of yellow pines, PlantB = dummy variable for clustered plantations, ThinY $=$ dummy variable for thinned plantations, shan. $\mathrm{H}=$ Shannon's diversity index.

Table 8. Mean and (standard deviation) of trees per hectare before and after thinning .56

Chapter 3.

Table. 1 Regeneration amounts in terms of trees per acre used after incorporating survival rates by species. The no management (a) scenario amounts were delineated by simulation age and TPH (trees per hectare). For treated stands (b) (mastication + prescribed burning, mastication only, thinning only) regen was only implemented after treatments and delineated by fuel treatment and thinning target.

Table 2. Matrix of treatments used in FVS simulations. SDI = Stand Density Index. Mast = mastication only, Mast + Burn = mastication with burning.

Table 3. Simulated prescribed fire and potential severe fire conditions. .88

Table 4. Description of fuel models from Scott and Burgan (2005) used in this study. 88

Table 5. P-values from three-way ANOVA. Fuels $=$ fuel treatment, thin $=$ thinning target, Trt $=$ original management. $*=$ significance at the 0.05 level

Table 6. Basal area $\left(\mathrm{m}^{2} \mathrm{ha}^{-1}\right)$ at end of simulation by thinning target and fuel treatment (Mast $=$ mastication only, $\mathrm{MB}=$ mastication with burning, $\mathrm{No}=$ No fuel treatment), values are averaged across all original management ("Total"). Different letters in the "Total" column indicate significant differences $(\mathrm{p}<0.05)$ between fuel treatments and different letters in the "Total" row indicate significant differences $(\mathrm{p}<0.05)$ between thinning targets. SDI $=$ stand density index....89 
Table 7. QMD (cm) at end of simulation by thinning target and fuel treatment (a) (Mast = mastication only, $\mathrm{MB}=$ mastication with burning, No = No fuel treatment) and original management (b) $(\mathrm{NRG}=$ natural regenerating stands, $\mathrm{PCT}=$ plantations with pre-commercial thinning, non-PCT $=$ plantations without pre-commercial thinning). SDI = stand density index.

Table 8. Mortality (\%) from prescribed fires by original management (a) (Trt: NRG = natural regenerating stands, $\mathrm{PCT}=$ plantations with pre-commercial thinning, non-PCT $=$ plantations without pre-commercial thinning), thinning target (b), and year of fire. Different letters in each column within Trt or Thinning target indicate a significant $(\mathrm{p}<0.05)$ difference in mortality. SDI $=$ stand density index.

Table 9. Surface and total flame lengths $(\mathrm{m})$ and spread rate $(\mathrm{m} / \mathrm{min})$ by fuel treatments $($ Mast $=$ mastication only, $\mathrm{MB}=$ mastication with burning, No Fuel $=$ No fuel treatment). Different letters in rows indicate a difference in flame length or spread rate between fuel treatments.

\section{List of Figures}

\section{Chapter 1.}

Figure 1. Effects of historic and restoration management on the wet and dry forests of the northwestern United States and California.

Figure 2. Map of mountain ranges of the northwestern United States and California showing the distribution of wet and dry forest types. Data usgs.gov.

Figure 3. A fire-suppressed mixed-conifer stand in the Sierra Nevada region of northern California. The overstory is dominated by sugar pine and ponderosa pine. The stand contains a dense understory of shade tolerant, fire sensitive white fir, and incense cedar. Photo Credits: Dr. Jianwei Zhang, 2008

Figure 4. Comparison of a traditional, evenly spaced plantation (a), and a novel clustered arrangement (b) in the mixed-conifer forest region of the Sierra Nevada, Eldorado National Forest. Photo Credits: Iris Allen, 2017

Chapter 2.

Figure 1. Location of Eldorado National Forest (gray) and the perimeter of the 2004 Power Fire (black) in Northern California.

Figure 2. Sampling locations within the 2004 Power Fire perimeter in the El Dorado National Forest, California. 58

Figure 3. Sampling diagram for $200 \mathrm{~m}^{2}$ plots. $\mathrm{r}=$ radius; $\mathrm{N}=$ North, $\mathrm{E}=$ East, $\mathrm{S}=$ South, $\mathrm{W}=$ West.......59

Figure 4. Incremental growth compared among all five treatment groups (Trt): (A) BAI before thinning and (B) annual height growth before thinning. Different lower case letters represent a statistical difference to the 0.05 significance level between treatments. Error bars represent $+/-1$ stand error (back transformed if a transformation was used).

Figure 5. Mean total height (A) and DBH (diameter at breast height) (B) across all 5 treatments (Trt). Different lower case letters represent a statistical difference to the 0.05 significance level between treatments. Error bars represent $+/$ - one standard error.

Figure 6. Trees per hectare (TPH) after thinning compared between all treatments (Trt). Same lower case letters represent no statistical difference to the 0.05 significance level between treatments. Error bars represent $+/-1$ back transformed standard error. 
Figure 7. Shrub height compared between all five treatments (Trt). Different lower case letters represent a statistical difference to the 0.05 significance level between treatments. Error bars represent $+/-$ back transformed standard error.

Figure 8. BAI before thinning compared among planting arrangement and thinning. Gray is not thinned and white is thinned. Error bars represent $+/-1$ back transformed standard error. BAI differed by planting arrangement $(\mathrm{p}=0.0427)$ and thinning $(\mathrm{p}=0.0006)$

Figure 9. Species richness (A) and Shannon's diversity index (B) compared among planting arrangement and thinning. Gray is not thinned and white is thinned. Error bars represent $+/$ - stand error. Both species richness and Shannon's diversity index different among thinning $(\mathrm{p}=0.0284$ and $\mathrm{p}=$ 0.0559 , respectively).

Figure 10. BAI thinning index ([BAI after thinning- BAI before thinning]/ BAI before thinning) compared between planting arrangement among plantations that were thinned. Error bars represent $+/-1$ back transformed standard error. There was a trend of BAI Index differing between planting arrangements $(\mathrm{p}=0.061)$.

Chapter 3.

Figure 1. Decision tree showing fuel model used in unmanaged simulations, only overstory thinning simulations, and initial conditions. SDI = stand density index; TPH = trees per hectare; see Table 4 or Scott and Burgan (2005) for full description of fuel model names in final white boxes........ 92

Figure 2. Potential fire type over time by fuel treatment (Mast $=$ mastication only, $\mathrm{MB}=$ mastication with burning, No = No fuel treatment), thinning target, and original management (Trt: NRG = natural regenerating stands, $\mathrm{PCT}=$ plantations with pre-commercial thinning, non-PCT $=$ plantations without pre-commercial thinning). Y Axis: $4=$ Active crown five, $3=$ passive crown fire, $2=$ conditional crown fire, $1=$ surface fire.

Figure 3. \% basal area mortality from potential fires over time by fuel treatment (Mast = mastication only, $\mathrm{MB}=$ mastication with burning, $\mathrm{No}=$ No fuel treatment), thinning target, and original management $(\mathrm{Trt}: \mathrm{NRG}=$ natural regenerating stands, $\mathrm{PCT}=$ plantations with pre-commercial thinning, non-PCT $=$ plantations without pre-commercial thinning).

Figure 4. Canopy base height minus total flame length from potential fires over time by fuel treatment (Mast = mastication only, MB = mastication with burning, No $=$ No fuel treatment), thinning target, and original management (Trt: NRG = natural regenerating stands, $\mathrm{PCT}=$ plantations with pre-commercial thinning, non-PCT $=$ plantations without pre-commercial thinning)

Figure 5. Interaction of fuel treatment (Mast = mastication only, $\mathrm{MB}=$ mastication with burning, No = No fuel treatment) and thinning target for A) basal area $\left.\left.\left(\mathrm{m}^{2} \mathrm{ha}^{-1}\right), \mathrm{B}\right) \mathrm{QMD}(\mathrm{cm}), \mathrm{C}\right)$ age when surface fire begins, D) age $\mathrm{CBH}$ exceeds flame length, and E) final crowning index (kph). Error bars are $+/$ - 1 standard error.

Figure 6. Crowning index from potential fires over time by fuel treatment (Mast = mastication only, MB $=$ mastication with burning, No $=$ No fuel treatment), thinning target, and original management (Trt: NRG = natural regenerating stands, PCT = plantations with pre-commercial thinning, nonPCT $=$ plantations without pre-commercial thinning).

Figure 7. Canopy base height over time by fuel treatment (Mast $=$ mastication only, $\mathrm{MB}=$ mastication with burning, No = No fuel treatment), thinning target, and original management (Trt: NRG = natural regenerating stands, $\mathrm{PCT}=$ plantations with pre-commercial thinning, non-PCT = plantations without pre-commercial thinning). 
Figure 8. Canopy bulk density over time by fuel treatment (Mast = mastication only, $\mathrm{MB}=$ mastication with burning, No $=$ No fuel treatment), thinning target, and original management (Trt: NRG = natural regenerating stands, $\mathrm{PCT}=$ plantations with pre-commercial thinning, non-PCT = plantations without pre-commercial thinning). 


\section{Chapter 1: Fire Management in Montane Forests of the Northwestern United States and California ${ }^{1}$}

\subsection{Introduction}

Disturbance, both biotic and abiotic, plays a very important role in shaping the montane forests in the northwestern United States and California. In the drier forests of this region, the natural fire regime is typically characterized as low-severity or understory fire regime, keeping forests with an open canopy (Arno and Allison-Bunnell, 2000; Brown and Smith, 2000). A low-severity regime is categorized as generally being non-lethal to the dominant above-ground vegetation where the survival rate of the dominant vegetation is $75 \%$ or more with low fire return intervals (1-30 years). The main exception to this are the dry, high-elevation forests which tend to experience high-severity, stand-replacing fires (Agee, 1993). The mesic forests also experience high-severity fires, with very long fire return intervals (Agee, 1993). High-severity fires are characterized as generally being very lethal to the dominant vegetation which experiences mortality rates of $80 \%$ or more (Brown and Smith, 2000). Compared to the low-severity regimes, high-severity regimes typically have longer fire return intervals (100-400 years). Mixed-severity fire regimes have effects that are intermediate mainly due to variations in topography (elevation and aspect) and microclimate that in turn lead to variations in forest vegetation type (Arno and Allison-Bunnell, 2000; Brown and Smith, 2000).

Human activities have altered these forests through their habitation of these forests for many centuries. Native Americans used fire as a tool for cooking, hunting, fishing, range management to encourage game animal foraging, manipulate plant growth, land clearing, and warfare (Anderson and Morrato, 1996; Boyd, 1999; Brown and Smith, 2000). However, it was not until European settlement, which began in the $18^{\text {th }}$ century that large-scale landscape alterations occurred. Practices from the past two centuries have transformed historical disturbance pattern, forest structure, and species. Historical ecology-based natural archives such as tree-rings have been used to reconstruct historical disturbance

\footnotetext{
${ }^{1}$ A version of this chapter was published in the journal "Fire" in April 2019
} 
regimes before the European settlement phase (Swetnam et al., 1999). There has been a loss of structural heterogeneity and an increase in density. These changes affect fire behavior, wildlife habitat, and ecosystem function. Land managers and scientists have noticed the ramifications of the past land management and have been working to find new management practices that incorporate landscape-scale forest restoration by maintaining natural disturbance regimes (Fig. 1). In particular, the practice of fire suppression has shifted fire regimes to a higher proportion of stand-replacement fires and lower proportion of low-severity fires compared to the pre-settlement fire disturbance regime (Arno and Allison-Bunnell, 2000).

The objective of this chapter is to provide a synthesis of fire management issues facing the mountainous regions of several northwestern states and California in the United States. The scope of fire management examined includes preventative activities such as fuel treatments and the policies of state and federal agencies that drive management activities. I focused on the large-scale activities that have resulted in landscape-scale changes in the forests. I divided the region into two main forests types — wet, like the forests in the Pacific Northwest, and dry, like the forests in the Sierra Nevada and Cascade ranges. Among these two types, I noted past logging history along with fire management practices, like fire suppression. Next, I looked at how historical management has influenced contemporary forest management challenges, like catastrophic crown fires, decreased heterogeneity, and climate change. I then synthesized what current management actions are performed to address these issues, like thinning and fuel treatments to reduce fire severity or improve structural heterogeneity, and restoration after largescale disturbances. Lastly, I took a brief look into the policy that has shaped these management actions.

\subsection{Study Area}

The northwestern United States and California have a large diversity of mountain ranges and forest types. The Rocky Mountains, which run 4800 km from Canada to New Mexico, are a major mountain range in western North America. Closer to the Pacific Coast, there are several mountain systems including the Coast Range, Sierra Nevada, Cascade, and Klamath ranges in California, Nevada, Oregon, 
and Washington (Fig. 2). The forest types can be divided into two major categories, dry and wet forests; this is predominately due to rain shadow and elevational effects from the mountain ranges. There are several different forest types found in the dry forests. In the mid elevations of the Sierra Nevada and Cascades, mixed conifer forests are composed of ponderosa pine (Pinus ponderosa Lawson and C. Lawson), sugar pine (Pinus lambertiana Douglas), white fir (Abies concolor (Gord. and Glend.) Lindl. ex Hildebr.), incense cedar (Calocedrus decurrens (Torr.) Florin), and several oak species (Quercus spp) (Old-Growth Definition Task Group, 1986). In the Rocky Mountains, mixed conifer forests are mainly composed of Rocky Mountain Douglas-firs (Pseudotsuga menziesii var. glauca (Mayr) Franco), and western larch (Larix occidentalis Nutt.) (Hejl et al., 1995). There is a continuum of moisture availability in mixed conifer forests, with moisture increasing as one travels upslope and to northerly aspects (Stine et al., 2013). There are also dry ponderosa pine and Douglas-fir forests in these ranges at low to mid elevations. Many dry forests in higher elevations consist of lodgepole pine (Pinus contorta Douglas ex Loudon) and whitebark pine (Pinus albicaulis Engelm) (North et al., 2009). The wet forests are mainly found in the coast ranges of Oregon and Washington. Western hemlock (Tsuga heterophylla (Raf.) Sarg) is a common species found in these forests, often mixed with Sitka spruce (Picea sitchensis (Bong.) Carrière) or coastal Douglas-fir (Pseudotusga menziesii var. menziesii). Western redcedar (Thuja plicata Donn ex D. Don) and Pacific silver fir (Abies amabilis (Douglas ex Loudon) Douglas ex Forbes) are commonly found in earlier successional mesic forests (Franklin et al., 2002).

\subsection{History of Management}

\subsubsection{Fire Suppression}

Forests in the dry regions of the northwestern United States and California are shaped by fire, thus humans' manipulation of fire has had a large impact on them. Fire regimes in the west were of low, mixed, or high severity, depending on the forest type (Stine et al., 2013). The drier forests like mixed conifer and ponderosa pine dominated forests tended to have frequent, low- to mixed-severity fires (Agee, 1993). Higher elevation forests like lodgepole pine dominated forests and the wetter forests closer to the 
coast, are adapted to large stand-replacing fires with their thin bark and serotinous cones (Agee, 1993). Aspect also plays a role on potential fire behavior due to differences is moisture; more southerly aspects have an understory fire regime while more northerly aspects tend to have a stand-replacement fire regime (Brown and Smith, 2000). The history of humans using fire to manage lands began long before European settlement in the Western United States in the late $18^{\text {th }}$ century. Native Americans would use fire to control the growth of certain plants and maintain grasslands to improve foraging for deer, a common source of food (Anderson and Morrato, 1996). Their use of the land had a substantial impact on resource availability and diversity of flora and fauna; at one point, there were around 100,000 Native Americans living in the Sierra Nevada (Anderson and Morrato, 1996). Unfortunately, during the $19^{\text {th }}$ century, Native American populations dramatically decreased due to multiple factors, including diseases from European settlers, (often forced) cultural assimilation, and violence (Hackel, 2012). This major decline in Native peoples' populations in the late $18^{\text {th }}$ century ended their widespread use of fire for land management (Taylor et al., 2016). The Native American communities use of fire for land management (Boyd, 1999) were based on traditional fire knowledge (e.g., fire effects on plants and animals) passed down from generation to generation within these communities (Christianson, 2015; Huffman, 2013).

After the major decrease in Native American populations, there were no widespread fire management practices until the United States federal government began managing land. The practice of fire suppression occurred mainly on public land managed by federal agencies such as the US Forest Service and National Park System (Stephens and Ruth, 2005; Van Wagtendonk, 2007). The practice of fire suppression began after the creation of the National Parks when the U.S. Army started to patrol them in the late $19^{\text {th }}$ century (Stephens and Ruth, 2005). Reduced fire in the late $19^{\text {th }}$ century also coincided with heavy fuel removal from extensive livestock grazing (Brown and Smith, 2000). In 1898, Gifford Pinchot was appointed as the head of the Federal Forestry Program, which then became the Bureau of Forestry in 1901, and then the US Forest Service in 1905 (Pyne, 1997). In 1908, after a series of extensive western fires, the prevention and control of fires was added to the charge of the US Forest Service (Pyne, 1997). The first two chiefs of the US Forest Service were strong proponents of fire suppression, believing 
that it was necessary in protecting forests (Stephens and Ruth, 2005). The Great Fire of 1910 in Montana, Idaho, and Washington further cemented the zero-tolerance policy for fires on federal land (Van Wagtendonk, 2007). This fire burned over 1.2 million hectares of land, killed 85 people, and destroyed several towns (Pyne, 2008). The passage by the US Congress of the Weeks Act in 1911 allowed cooperative agreements and matching funds between the US Forest Service and state forestry management agencies to broaden fire protection on public and private lands (Arno and Allison-Bunnell, 2000). The Weeks Act also provided for the US government to purchase land to set up the National Forest system which enabled the government to more effectively manage the lands. The Agricultural Appropriations Act of 1912 allowed 10\% of the funds generated from the National Forests to be used in the construction of roads and trails which in turn improved access in the event of fires. In 1916-1917, the National Park Service was established, and 13 National Parks were founded primarily in the western United States (Albright and Schenck, 1999). The passage of the Clarke McNary Act in 1924 greatly expanded the cooperative fire protection program between the federal and state agencies (Arno and Allison-Bunnell, 2000). The 10 a.m. policy was put in place in 1935, stating that all fires on federal land should be extinguished by 10 a.m. the next day (Dale, 2006). The Civilian Conservation Corps (CCC) program was established by the US Government and ran from 1933-1942 (Pyne, 1997). The CCC contributed to fire prevention and firefighting, including the construction of fire lookout towers. For instance, the CCC assisted with fighting the 1933 Tillamook Fire (Pyne, 1997). Fire suppression remained the Forest Service's main fire practice until the 1970s (Van Wagtendonk, 2007). During this time period, there were voices in the Forest Service and National Park System that were calling for a better understanding on fire's use in the ecosystem, but they did not have any large effect over national policy until later in the 20th century (Van Wagtendonk, 2007). Some other federal agencies such as the US Fish and Wildlife Service (FWS) conducted the first recorded prescribed fire in 1927 in the St. Mark's National Wildlife Refuge (US FWS (Fish and Wildlife Service), 2014). Recognition of the benefits of prescribed burning for land management were noted by ecologists working in the southeastern pine forests (Chapman, 1932; Stoddard, 1931). In Idaho and Montana, Elers Koch (1935), a regional forester 
for the U.S. Forest Service, promoted wilderness values and expressed concerns over fire suppression. Effects of prescribed burning were examined in ponderosa pine forests in the mid-20 th century (Biswell, 1960; Weaver, 1952). It was not until the 1960s that the National Park System began to allow fires to burn on their land and some prescribed burning (Stephens and Ruth, 2005; Van Wagtendonk, 2007).

Large fires in the late $20^{\text {th }}$ century did lead to a more cohesive approach to managing fire on a national level. The Yellowstone fires and the Canyon Creek Fire both occurred in the summer of 1988 and burned 500,000 and 100,000 hectares of land, respectively (Turner, 2010; Van Wagtendonk, 2007). After these fires, the Secretaries of the Interior and Agriculture performed a review on fire policy on National Park and Forest Service wilderness lands (Van Wagtendonk, 2007). This review in 1989 called for a change in fire management policy, to make it more straightforward and improve interagency cooperation. After this review the National Parks and Forest Service began to allow more fire on their lands (Rothman, 2007; Van Wagtendonk, 2007). Another fire that shaped more recent fire policy was the 1994 South Canyon fire in Colorado. This fire killed 12 firefighters after a blow-up following suppression activities (Van Wagtendonk, 2007). After this fire, the review and update of fire management and policy on all federal lands was written (U.S. Department of the Interior and U.S. Department of Agriculture, 1995; Van Wagtendonk, 2007). This report prioritized firefighter and public safety, but also acknowledged the ecological need for fire on the land and provide recommendations on how to reintroduce fire back onto federal lands (U.S. Department of the Interior and U.S. Department of Agriculture, 1995). In 2000, the Departments of the Interior and Agriculture created the National Fire Plan (U.S. Department of the Interior and USDA Forest Service, 2002). The plan focused on collaboration between federal, state, tribal, and local agencies to identify areas at high fire risk and develop strategies to restore fire-adapted ecosystems in these areas (U.S. Department of the Interior and USDA Forest Service, 2002). Another aspect of the plan was to assess the feasibility of creating a uniform fire planning system across the different agencies (Roose et al., 2008). Jim Hubbard, a state forester from Colorado, was assigned that task and created the "Hubbard Report" which lead to the creation of the Fire Program Analysis system (Roose et al., 2008). In 2009, the FLAME act was passed 
which lead to the creation of the National Cohesive Wildland Fire Management Strategy (U.S.

Department of the Interior et al., 2014). The National Strategy includes guidelines for fire management activities that prioritize safety, fuel management, and community engagement, and is still the Nation's fire policy (U.S. Department of the Interior et al., 2014).

However, despite the advances in fire policy, fire suppression is still a major practice of the US Forest Service (Calkin et al., 2014; Stephens and Ruth, 2005). Even with the progress made in understanding the important role fire plays in these ecosystems and implementation of prescribed fire and fuel reductions, there are still major risks and limited incentives to let wildfires burn (North et al., 2015). This is partly due to many people moving to and living in the Wildland Urban Interface, areas where homes are located amongst unoccupied spaces, like forests and grasslands (Redeloff et al., 2005). As a result, the US Forest Service spends nearly 50\% of their annual budget on fire suppression (Calkin et al., 2014). By altering the natural disturbance pattern of the landscape, fire suppression has also altered the structure and function of the landscape (Fig. 1).

\subsubsection{Logging}

The historic logging regime in montane systems usually depended on the forest type. The management of wetter forests, found further north and closer to the coast, historically relied on clear cuts (Fig. 1). Large-scale logging began in the Pacific Northwest (PNW) to supply California's population boom associated with the gold rush in the mid-1 $9^{\text {th }}$ century $($ Cox, 1974). As more people moved into the Pacific Northwest, more of the huge old-growth forests were cleared and mill towns were created to house the lumber workers and their families (Cox, 1974). The timber industry employed $63 \%$ of wage earners in Washington State and 52\% in Oregon in 1915 (Dumont, 1996). The completion of a railroad line in the late $19^{\text {th }}$ century and the depletion of timber in the Lake States greatly increased timber demand from the Pacific Northwest, making it one of the main suppliers for lumber in the United States (Chiang and Reese, n.d.). In the early 20th century, Frederick Weyerhaeuser (timber mogul and founder of Weyerhaeuser timber company) purchased over 405 thousand hectares of timber land in Washington which greatly expanded industrial forestry in the PNW (Chiang and Reese, n.d.). Industrial loggers 
worried that the creation of the Forest Reserve Act and the Forest Service would slow down the rate of harvest, but Gifford Pinchot, the first head of the US Forest Service, was a supporter of the timber industry. He encouraged companies to cut "virgin" forests and regenerate them to allow for sustainable yields over time (Chiang and Reese, n.d.). This system of cutting old growth forests and replacing them with single species plantations continued after Pinchot and was the main forestry practice from the 1940s to the 1980s (Swanson and Franklin, 1992). The rise of conservationism in the mid-20th century and environmentalism in the later 20th century, including concern with the Northern Spotted Owl, eventually lead to a decline, or complete elimination in many places, of the timber industry (Dumont, 1996). However, the legacy of those practices is still felt on the land since these logging operations had a tendency to shorten the fire return interval in the wet forest regions (Fig. 1).

The drier forests, found further south and inland, did not experience the same intensity of clear cuts, but these lands were still harvested, which has resulted in lasting impacts (Fig. 1) (Biswell, 1960; Rothman, 2007; Turner, 2010). Unlike the clear cuts found in the moist forests in the Pacific Northwest, the drier forests had more selection cuts performed (Fig. 1). These dry forests mostly consist of ponderosa pine or mixed conifer forest type, which used to have many more large trees, when compared to today, that were interspersed with openings (Hessburg et al., 2005). Logging efforts in these forests were focused on the largest, most timber worthy trees, usually ponderosa, Jeffery, and sugar pine (Hessburg and Agee, 2003; Laudenslayer and Darr, 1990; Stine et al., 2013). This left much smaller residual trees; in the Sierra Nevada mountains, this often meant an lower cutting limit of $31 \mathrm{~cm} \mathrm{DBH}$ (diameter at breast height), although by the 1930s there were requirements for leaving trees 61 to $71 \mathrm{~cm}$ on some lands (Laudenslayer and Darr, 1990). This practice of high-grading, selectively harvesting the best, largest trees, leaving behind the small trees, was common practice in the dry forests of California along with the Inland Northwest (Hessburg and Agee, 2003; Laudenslayer and Darr, 1990). The harvests also required an extensive number of roads and train tracks be put in, to get the logs to the mills (Hessburg and Agee, 2003). Harvests would usually work across large sections of land, as the earnings from the harvest needed to outweigh the cost of roads and train tracks, so it was more cost effective to stay in one large area 
(Laudenslayer and Darr, 1990). While these logging practices differed from the wet forests, these methods also altered and fragmented the forests and induced structural changes that decreased the dominance of fire tolerant species.

\subsubsection{Land Ownership}

In addition to the management history of these lands, land ownership patterns also provide important context for understanding the issues that forests in the United States face. One usually finds different management, historical and current, on private and public forests. In the western United States, a majority of the forested land is public, with $64 \%$ of the forested area under the federal government (Butler, 2012). In terms of forest type, the wet forests in the Olympic Peninsula and Oregon and Washington Coast range have a higher proportion of private ownership compared to the dry forest mountain ranges of the northwestern United States and California (U.S. Department of Agriculture (USDA) Forest Service, 2010) (Fig. 2). In California's 13.4 million hectares of forests, $56 \%$ is managed by the federal government, with $47 \%$ in national forests, $5 \%$ in Bureau of Land Management land, and $4 \%$ in the National Park System (Christensen et al., 2008). In Washington State, about 57\% of the forested land is public (Erickson and Rinehart, 2005). The remaining forested areas belong to small local and state agencies or are on private hands. Having a majority of the land under federal control has advantages and disadvantages. It allows for management at the landscape scale, which can help control the spread of disturbances like fire and insects. However, this also means resources for management of these areas are controlled by the federal budget, which is increasingly limited due to more and more of the budget going towards firefighting efforts in the recent years (Steelman, 2016). Also, having such a large area of land can make it challenging to have a management plan that address all the area's needs.

\subsection{Current Issues}

\subsubsection{Increasing Fire Risk}

In dry, northwestern and Californian forests, fire suppression has altered structure, which in turn has increased fire risk (Arno and Allison-Bunnell, 2000; Brown and Smith, 2000; Schoennagel et al., 2017). Mixed conifer and dry pine forests, common forest types in the western United States, historically had a 
fire regime with frequent surface fires of low to mixed severity (Agee, 1993) (Fig. 1). These fires shaped the relatively open canopy forest structure (Stephens et al., 2008). This historical fire regime has changed in the past century due to fire suppression (Fig. 1). Due to lack of fires, unforested openings have become smaller and fragmented (Skinner, 1995). Forest that were historically kept less dense by fire now have increased canopy cover due to lack of fire (Hessburg et al., 2000) (Fig. 1). This pattern of increased forest cover due to fire suppression has been detected in the Rockies, Sierra Nevada, Cascade, and Klamath ranges (Hessburg et al., 2000; Skinner, 1995; Stephens, 2005; Stine et al., 2013). In response to increases in forest density and cover, changes in fire behavior have been observed in areas with historically low to moderate fire regimes (Miller and Safford, 2012) (Fig. 1). However, there is still debate over exactly how fire trends are changing, especially when it comes to areas of high-severity fires (Hanson and Odion, 2014; Miller et al., 2009; Miller and Safford, 2012; Morgan et al., 2017). While the specifics of fire regime change are not clear, the past few years have witnessed several fires that approach state records. In 2013, the third largest fire in California's history burned through a mixed conifer forest on the Stanislaus National Forest and Yosemite National Park. The fire was over 100,000 hectares, well outside of historic fire extent, and pre-fire forest structure suggested that a majority of the burned area had not experienced a fire for more than a century (Harris and Taylor, 2015).

The shift in fire regimes in western forests has had adverse effects on human livelihoods and wildlife habitat. Approximately 39\% of housing units in the United States are located in the wildland urban interface (WUI) (Redeloff et al., 2005). Many of these homes are found in the western United States especially in California and Colorado, and homes located in the WUI are at greater risk for wildfires (Covington, 2000). Given this, and the fact that annual area burned by wildfire has increased in the past decade, these homes will soon be in direct danger from fire, if they are not already (Stephens and Ruth, 2005; Stine et al., 2013). In addition to damage to human structures, these atypical (i.e., arising from an altered fire regime) large fires harm the forest habitat and resilience. The California spotted owl, Strix occidentalis, is a species of concern that is negatively affected by large wildfires (Jones et al., 2016; North, 2012; Stephens et al., 2016). They are associated with late successional forests, with high canopy 
cover and complex structure (North, 2012). However, their preferred habitats now have a high-severity fire risk due to an accumulation of fuels from fire suppression (Jones et al., 2016; North, 2012; Stephens et al., 2016). When high-severity wildfires burn the owls' range, they lose nesting habitat and the canopy cover they require, which has resulted in a sharp decline in their populations (Jones et al., 2016; Stephens et al., 2016). In addition to the loss of habitat, the forests have trouble recovering from the atypical large fires, as they are not adapted to them (Collins and Roller, 2013; Welch et al., 2016). Often, seed trees are killed, impeding natural regeneration (Bonnet et al., 2005; Donato et al., 2009). This often delays their recovery, further displacing wildlife. It is important to note that not all fires cause this damage, only the large, atypical ones with high overstory mortality.

\subsubsection{Structural and Functional Changes}

Historic silviculture practices before the 1990s in the moist forests of the Pacific Northwest have decreased stand structural complexity, which in turn can affect wildlife habitat and watershed conditions (Fig. 1). Before European settler intervention, these forests were old, over 175 years, and structurally complex (Fig. 1) (Franklin et al., 1981). There was a mix of trees of all sizes, including very large, old trees, along with standing dead trees, snags, and diverse understory plant species (Franklin et al., 2002). The diversity of structure and dead and decaying material created habitat for many species and facilitated nutrient cycling (Franklin et al., 2002). However, most of this structural diversity is lost when areas are

clear cut and replaced with either natural regeneration or plantations (Fig. 1). The loss of complex habitat harms species like the Northern Spotted Owl, which was listed on the Endangered Species Act in 1990 due to habitat loss and fragmentation from forest management and logging (Franklin and Gutierres, 2002). This loss of woody debris also affects forest streams as many aquatic species rely on in stream wood for habitat (Benda et al., 2016).

Drier forests have also experienced a decrease in habitat diversity, but to a different extent. These forests were previously characterized by a horizontally heterogeneous landscape with trees clustered in groups ranging in age and size, spaced out with small openings filled by herbaceous plants and shrubs (Stephens et al., 2008) (Fig. 1). However, due to fire suppression and logging, the forests have become 
more dense and homogenous (Naficy et al., 2016; Stine et al., 2013) (Fig. 1). Due to selection harvesting of the largest pines in the past, the density of large trees in stands has decreased (Hessburg et al., 2000; Stine et al., 2013) (Fig. 2). Conversely, the amount of shade-tolerant conifers, like white fir and incense cedar, have increased (Hessburg et al., 2000). These trees would have been controlled with low-severity fires but are now able to outcompete shade-intolerant pines for moisture and growing space due to fire suppression (Fig. 3). The competition in return increases mortality of the larger old trees. Fire suppression is also responsible for a decrease in non-forested area. Shrubs and chaparral used to be a common element in dry western forests, often resprouting after fires. Shrub lands have been replaced by forest, reducing landscape heterogeneity (Nagel and Taylor, 2005). The decrease in heterogeneity and increase in density also puts the forests at a greater risk for large scale insect and fungal outbreaks (Fettig et al., 2007) (Fig. 1). Increased tree mortality from insect pests and fungal pathogens in turn increase the likelihood that surface fires will easily transition into crown fires due to the standing dry, dead fuel (Edmonds et al., 2011). The landscape heterogeneity can act as ecological insurance, allowing for the forest to persist even if a small section was harmed. However, as the forests become denser and homogenous, large disturbances, such as diseases, insects, and wildfires, are able to spread throughout the whole stand. Forests with mixed-severity fire regimes have shown increases in stand density during the $20^{\text {th }}$ century with negative implications for stand structural complexity and reduced functional aspects such as beta diversity (which is the ratio between regional and local species diversity); this decreases heterogeneity of successional stages, which safeguard forest health (Hessburg et al., 2016; Perry et al., 2011).

\subsubsection{Climate Change}

Current climate warming principally stems from anthropogenic emissions and this trend from the pre-industrial period to the present will persist for centuries (IPCC, 2013). Some authors suggest it is imperative that forest resource managers develop adaptation strategies to climate change and induced changes in disturbance regimes (Millar et al., 2007). With this altered climate, warmer temperatures, decreased snowpack, earlier snowmelt, increased summer evapotranspiration, and more frequent and severe droughts are expected (Chmura et al., 2011). All of these changes will affect forest function, and 
some already have (Fig. 1). Warmer temperatures may increase productivity in some forests, however trees have a heat injury threshold, which, if passed, can damage cells, affecting metabolic processes (Chmura et al., 2011; Vose et al., 2018). Drought can harm trees by causing cavitation of water columns and water-stress-induced carbon starvation, reducing ability to defend against biotic attacks (Allen et al., 2010). Often, the combination of elevated temperatures and drought is what kills trees (Clark et al., 2016). Large patches of water-stressed and even dead trees can be seen throughout the northwestern United States and California, with extreme mortality events in the southern Sierra Nevada Mountains (Stephens et al., 2018; Vose et al., 2018).

Climate change's effects on weather and tree mortality in turn are altering forests' disturbance regimes (Turner, 2010). Many of the dry forest areas already have weather systems that support fire. Foehn winds, often called "chinook" winds in the Rocky Mountains and "mono" winds in the central Sierra Nevada, are fast, dry, warm winds that flow downslope (Gedalof et al., 2005). The high peaks of the ranges also block and divert moisture away from the region. These hot, dry, windy characteristics create conditions conducive to the ignition and spread of fire (Gedalof et al., 2005). Climate change is making areas that are already prone to fire even more prone to it (Stephens et al., 2013) (Fig. 1). Wetter forest types tend to have longer fire return intervals and climate change inducing more frequent fires disrupts this pattern (Westerling and Bryant, 2007) (Fig. 1). There are also climate change predictions for decreased or less consistent precipitation, which creates drier fuels, thus increasing flammability (Abatzoglou et al., 2017). The effects of drought have already been observed in California. Individual fires are burning longer, and the fire season has lengthened due decreased snow pack (Westerling et al., 2006). This increased climate-related fire risk compounds with the increased forest density, putting these forests at a real risk for large, stand-replacing fires.

In addition to increasing fire hazard, climate change is also changing forest structure and exacerbating other issues, like fungal pathogens and insect pests. Warming temperatures shift many species habitats up in latitude and or elevation (Moritz et al., 2008). This is especially a problem for species that live on mountains, as they have a limited amount of space to move up to (Moritz et al., 2008). 
The landscape scale morality events from fungal pathogens and insect outbreaks in recent years are outside of historical norms (Fig. 1) (Vose et al., 2018). A warming climate has allowed pathogens into areas that used to be too cold for survival, thus infecting more trees (Bentz et al., 2010). In Yellowstone National Park, the high-elevation whitebark pine forests historically only faced short, infrequent outbreaks of mountain pine beetles. This was due to the high-elevation conditions being too cold for the

beetle. Now, however the beetle is able to overwinter in whitebark pine stands, and in some areas killing more than $95 \%$ of the cone-bearing trees and is projected to continue killing trees as the climate warms more (Logan et al., 2010). As mentioned before, climate change has created more drought conditions in dry forests (Allen et al., 2010; Vose et al., 2018) (Fig. 1). These drought conditions create stressed trees, which make them more susceptible to attack (Vose et al., 2018). The large, drought-related mortality event seen in the southern Sierra Nevada Mountains has been exacerbated by bark beetles killing the already water-stressed trees (Vose et al., 2018). Tree mortality during a hot and dry decade (2003-2012) in the western United States showed regional differences where mortality was attributed more to harvesting in the states of Washington and Oregon, while mortality due to bark beetles was more of a concern in Colorado and Montana, and mortality was mainly driven by fire in the state of California (Berner et al., 2017).

\subsection{Current Management}

\subsubsection{Fuels Treatment}

In efforts to restore historical fire regimes and reduce fire hazard, thinning and fuel reduction treatments to decrease fire risk are often used (Fig. 1). Given the amount of change that has happened in these forests, active management is needed to adequately restore them (Agee, 2002). Fuel reduction can be a strong tool but given the extent of fire suppression in the western United States, specific strategies are needed to make it effective. Focusing fuel reduction in areas with low- to mixed-severity fire regimes will provide the largest impact, as these forests have diverged the most from their historic structure and disturbance regimes (Agee, 2002) (Fig. 1). Performing the right type of fuels reduction is also important. 
Agee and Skinner (2005) laid out four principles for effectively reducing extreme fire behavior in fire adapted, dry forests: (1) surface fuels must be reduced to decrease potential flame length; (2) height to live crown must be increased so that longer flames lengths are required for a torching; (3) the overall density of trees should be reduced to decrease the ability for a crown fire to spread; and (4) maintain the largest, fire-resilient species because larger trees are more resistant to fatal fire damage. A common technique to alter the nature of fine fuels is mastication (Knapp et al., 2011; Kobziar et al., 2009; Kreye et al., 2014; Reiner et al., 2012, 2009). Mastication usually shreds or chips smaller trees, branches, and understory shrubs, thus relocating ladder fuels to the surface (Kreye et al., 2014). However, especially when used in young stands and plantations, it often needs to be accompanied by prescribed fire to effectively reduce fire behavior (Knapp et al., 2011; Kobziar et al., 2009; Reiner et al., 2012). Reducing fuels using these principles has been shown to reduce high-severity fire risk in many scenarios (Agee and Skinner, 2005; Knapp et al., 2011; Kobziar et al., 2009; Lyons-Tinsley and Peterson, 2012; North, 2012; North et al., 2009; Reiner et al., 2012; Safford et al., 2012; Schmidt et al., 2008; Stephens and Moghaddas, 2005a). Spatial arrangement of the treatments also influences their effectiveness. Strategically placed area treatments (SPLATs) are areas of thinning placed in the forest to slow the spread of fire at a landscape-scale (Finney, 2001). When fire behavior is modeled, SPLATs effectively reduce high-intensity areas burned (Schmidt et al., 2008).

Prescribed burning is another common fuel-reduction technique, and when used in tandem with thinning, is most effective at reducing crown fire risk (Fig. 1). One of the main problems with only thinning forests to reduce fuels is that it can often leave residues, actually increasing surface fuels (Agee and Skinner, 2005). Prescribed burning can significantly reduce litter and surface fuels, reducing fire intensity (Stephens and Moghaddas, 2005a). When forests have an abundance of ladder fuels, thinning medium-sized trees followed by prescribed burning has the largest effect on fire behavior (Schmidt et al., 2008; Stephens and Moghaddas, 2005a). Besides reducing fuel loading and risk of crown fire, prescribed burning can be used for restoring some ecosystem processes. Giant sequoia, the world's largest tree that is only naturally found in California's Sierra Nevada Mountains, relies on fires for regeneration (Hartesveldt 
et al., 1975). Unfortunately, due to a history of fire suppression, many white firs have encroached on their habitat, affecting regeneration. However, understory thinning and prescribed burning positively affect seedling success as it reduces light competition and encourages the serotinous cones to open (Meyer and Safford, 2011). It is important to note that prescribed burning is not a perfect solution for all restoration projects (Heumann, 2009). Prescribed burning can be risky in areas with steep topography, as fire travels quickly up steep slopes, so it is difficult to control prescribed burns in steep areas (Dillon et al., 2011). Prescribed burning in unthinned, dense stands also poses a risk of uncontrollable wildfires, as the ladders fuels that are responsible for crown fires are still there (Hessburg et al., 2016; Perry et al., 2011). While there are some very small risks associated with prescribed burning, in an overwhelming majority of its uses, little damage is done (Yoder et al., 2004). Despite their low likelihood of damage, the public still views prescribed fire as inherently risky (Yoder et al., 2004).

\subsubsection{Thinning to Increase Heterogeneity}

Land managers are now factoring in ecological concepts into their practices in order to encourage and create structural heterogeneity in forests. The pattern of spacing out cuts throughout the landscape is still being used, but with modifications. The size and structure of the patches have a large influence on habitat. Evenly spaced cuts increase the amount of habitat fragmentations, so clustering cuts and maintaining undisturbed connectivity is an important practice (Franklin and Forman, 1987) (Fig. 1). Cuts can also be used to increase woody debris in streams, improving fish habitat (Benda et al., 2016). Another important ecological principle included in new management plans is the inclusion of biological legacies, like old trees and standing dead trees (Fig. 1). Leaving these legacies help maintain important habitat and function (Franklin et al., 2002). Franklin and Johnson (2012) created a management plan for wet western forests that attempts to do so. They suggest a variable retention harvesting system, creating a heterogeneous landscape with patches of cuts (Fig. 1). The cuts would be focused in previously harvested stands and would maintain $30 \%$ of the preharvest stand structure, like live trees, snags, and logs (Franklin and Johnson, 2012). The variable retention harvesting system could also encourage development of diverse early seral ecosystems, an important functional stage in western mesic forests that is in limited 
supply (Franklin and Johnson, 2012) However, these practices are often encouraged but not wholly implemented.

While a majority of the suggested thinning treatments in dry western forests focus on reducing fuels and thus crown fire danger, increasing stand heterogeneity is another treatment goal (Fig. 1) (Stine et al., 2013). There is a shifting focus to a local scale for implementing restoration techniques. Adapting crown class, species preference, and stocking density requirements for individual stands help meet the specific needs of each stand (North, 2012). Using local topography to determine target densities and species helps emulate the original composition of the landscape and help create stand heterogeneity (North et al., 2009). These forests were originally composed of a patchwork of clusters of trees and openings. Specifically incorporating these elements into restoration treatments ensures that those historic structures return. A new approach incorporating individuals, clumps, and openings (ICO) has created a framework to categorize and create these elements (Churchill et al., 2013). Focusing on retaining spatially explicit elements in the forest helps maintain important ecological process and maintain wildlife habitat (Larson and Churchill, 2012). Lower tree density also benefits the tree's physiology. Dry forests that are more open and heterogeneous are less susceptible to drought damage (Stephens et al., 2008). Thinning has also been shown to reduce water stress (North et al., 2009). However, it is important to acknowledge that creating local scale management plans requires an immense amount of work and will take coordination across different agencies and land owners to implement.

\subsubsection{Use of Plantations after a High-Severity Fire}

Conifer regeneration after high-severity fires is extremely variable (Collins and Roller, 2013; Welch et al., 2016). Often shrubs will dominate the post fire landscape due to their persistent soil seed bank (Nagel and Taylor, 2005). Shrubs can out compete the conifer seedlings for light and water, delaying conifer regeneration for decades, if not centuries (Russell et al., 1998). In addition to the increased competition, seed source trees are killed during stand-replacing fires, preventing the establishment of the next generation of trees (Bonnet et al., 2005). To aid with forest reestablishment, targeted tree species are often planted after stand-replacing fires and are usually more successful than natural regenerating stands 
(Collins and Roller, 2013) (Fig. 1). However, these plantations require intensive management to survive. Controlling for shrubs mechanically or with herbicide is also extremely important in plantation success, as shrubs can outcompete tree seedlings (McDonald and Fiddler, 2010; Tappeiner and McDonald, 1996; Zhang et al., 2008). Salvage logging is often performed before planting to remove fuels and safety hazards and provide income to fund other management activities (McGinnis et al., 2010), although salvage logging does not yield many ecological benefits (Hessburg et al., 2016). Slash leftover from the fire and logging can hinder the success of plantations, so it is often piled and burned to encourage or discourage certain species from regenerating (Tappeiner et al., 2015).

While plantations can be successful at establishing trees quickly, there are several common criticisms. Their dense, homogenous nature results in a high density of canopy and surface fuels, which put them at risk for high-severity fire (Kobziar et al., 2009; Lyons-Tinsley and Peterson, 2012; North et al., 2019; Zald and Dunn, 2018). Plantations at high density are also at risk for drought-induced damage or mortality (Cannell, 1999). When compared to naturally regenerating stands, plantations often exhibit lower vegetative diversity in the early stages (Stephens and Wagner, 2007). Plantations are also lacking in spatial heterogeneity, so many of the problems associated with homogenous stands, like quick spread of disease and lack of wildlife habitat, are found in them (Fettig et al., 2007). As forest plantations become a more common method for rapid forest restoration, all aspects of ecosystem health and structure like diversity and resiliency to drought need to be addressed if they are to achieve their target of restoring the older forests conditions.

While most plantations are historically planted in evenly spaced rows, some restoration projects plant them in small, clustered aggregates, (Fig. 4) (Eldorado National Forest, 2014; North et al., 2019). This is attempting to mimic the natural clumping pattern of historical mixed conifer forests. Until the 2019 Tamm Review (North et al., 2019), there have not been any formal studies on this style of plantations in the United States. Commonly used square planting patterns were designed to maximize the productive capacity of the site by offering each seedling an opportunity for a relatively equal share of sunlight condition as well as site nutrients and moisture resources; this methods is also logistically efficient. 
Although many foresters wonder if a clustered arrangement will yield a forest stand within a reasonable time frame, there could be some potential benefits to a clumped arrangement. Tree ring analysis has shown trees in clumped patterns are resilient to moisture and fire stress (North et al., 2019). Having a spatially heterogeneous stand can break up crown and fuel continuity, thus reducing fire severity (Miller and Urban, 2000; Stephens et al., 2008). Most conifers require bare mineral soil, adequate soil moisture, light shade, and minimal competition for regeneration (Cooper, 2006; Tappeiner and McDonald, 1996). All these variables could potentially be altered by the spatial arrangement of the planted seedlings.

\subsubsection{Shift in Policy}

The Forest Reserve Act in 1891 allowed the president to set aside forest reserves on public land (Stephens and Ruth, 2005). Over the following few years, the extent of these reserves expanded along with the Forest Service Organic Management Act of 1897, which gave the secretary of the interior the power to regulate use on the reserves (Glasser, 2005). This network of public lands, which later became the National Forest system, allowed for policies, like the "10 a.m." fire suppression practice to be widely implemented. It was not until later in the 20th century that new policy passed with the goal of restoring ecosystems to historical structure and function. There were policies like the Resource Planning Act of 1974 and the National Forest Management Act of 1976, which required the National Forests to write forest management plans and regulate timber harvesting, and also outlined a planning rule that describes how public stakeholders can be involved in the planning process and how decisions are subject to objections (USDA Forest Service, 2004). The Endangered Species Act, which came out in 1973, has strong language, stating that critical habitat of listed species cannot be harmed (Bean, 2009). This had a huge impact for management of species like the spotted owl. It created regulations on private lands, which have fewer protections than federal lands (Suzuki and Olson, 2008). Another impactful piece of legislation was the 1994 Northwest Forest Plan (NWFP). The NWFP created a network of reserves throughout the Pacific Northwest and worked to relieve part of the burden put on private landowners to manage wildlife species (DellaSala et al., 2015). A new science synthesis for the NWFP was recently released that has new science informing management in the PNW since the original publication (Spies et 
al., 2018). There is a similar plan for the forests of the Sierra Nevada called the Sierra Nevada Forest Plan (USDA Forest Service, 2004). These laws and plans had a significant impact of forest management since it provided administrative control of larger and more contiguous areas of public land, which makes it more effective for addressing issues related to forest health, including fire management (Cortner et al., 1996).

In 2003, the Health Forests Initiative was implemented as a response to the severe 2002 fire season. Its goals were to expedite fuels treatments by reducing regulations surrounding forest cuttings (Neznek, 2004). Unfortunately, many people viewed this policy move as simply a way to reduce environmental regulations for the benefit of logging companies (Johnson et al., 2006). Another problem with current national fire policy is that there is still a lot of operating budget put into fire suppression and there is not enough left for fuels reduction. However, this issue is expected to improve starting in 2020 following the firefighting bill that the Congress has passed in 2019 which appropriated more funds to fuel management (United States. Cong., 2019). As of 2014, annual spending on fire suppression is over 1 billion dollars (Calkin et al., 2014). Also, many fuel treatments that are implemented focus on only reducing the amount of fuels instead of looking how to reduce severe fires on the landscape level (Stephens and Ruth, 2005). Schoennagel et al. (2017) caution that site-level fuel treatment reductions will not have a substantial impact on affecting regional wildfire behavior. They also promote a system of treatment triage in which critically important ecosystems and communities in the wildland urban interface areas are initially targeted for fuel reductions. There is also conflict between protecting wildlife and fuel treatments. The strict protections under the Endangered Species Act can often delay or hinder fuel reductions when they need to occur in critical habitat (Stephens and Ruth, 2005). The NWFP has also experienced some pushback. It has not met its commitment for timber sales, and many argue that it is harming the rural communities that rely on logging (DellaSala et al., 2015). There is no definite policy solution to perfectly manage forests. That is why it is important to make legislation adaptable to new science and incorporate all stakeholders. 
There are differences in policy and management framework for addressing wet and dry forest types in the mountain ranges of the northwestern United States and California. In comparatively wetter forest types, stand-replacing fires still serve an ecological role. The key concern in these wetter forest types is that a potential shortening of the fire return interval associated with climate change may lead to recruitment failure because trees may not get a chance to reach a seed-bearing age (Scott et al., 2014). In the drier forest types, the main policy goal is to restore an understory fire regime in these forest types (Scott et al., 2014).

\subsection{Conclusions}

The legacy of past management in northwestern and Californian montane forests is still seen. Fire suppression in frequent-fire forests and logging practices throughout the ranges left many of these forests more homogenous, fragmented, and overly dense. The transformed forests experience problems with wildfire, lack of wildlife habitat, and loss of function. In their current state, the disturbance regimes in these forests have been altered to the point that they have trouble recovering from the new disturbances. However, some management practices work to restore ecosystem function and historic disturbance regimes. Through different thinning and fuels treatments, structural heterogeneity and historic fire regimes can be worked back into these systems. In the past few decades, there has also been an increase in legislation working to help these forests, although some legislation is more effective than others. Restoring the forests' structure and function will require active management implemented on the local and landscape scale while taking into account climate change. With expected climate-induced changes in fire frequency and scale, fuel treatments will likely need to be implemented in dry forests to ensure they have an understory fire regime. With respect to wet forests in this region, it is suggested that there is still a place for stand-replacement fire regimes. However, these forests will require structural changes incorporating heterogeneity to improve their resilience. 


\subsection{General Research Goals and Thesis Structure}

The goal of my thesis is to identify the best tools to use for reforesting land after a large wildfire and keep it fire safe as the forest develops. I aim to do this with two research projects that focus on young mixed conifer plantations installed after a large, high severity fire in California's Sierra Nevada Mountains. The first project (chapter 2) tests the difference between the clustered and evenly spaced plantations and naturally regenerating stands. I compare diameter and height growth as well as density variables, shrub characteristics, and understory diversity. I also identify the best predictor variables for diameter and height growth before and after thinning. The second project (chapter 3) takes the growth data from the first project and uses the Forest Vegetation Simulation (FVS) and its Fire and Fuels Extension (FFE) to model growth and fire behavior 100 years into the future. In these simulations I test different fuel and thinning treatments to identify the most effective way to maximize growth and reduce risk of crown fires. My goal for my research is to aid land managers in making the most effective decision on how to reforest and manage their land after a large wildfire. 


\subsection{Works Cited}

Abatzoglou, J. T., Kolden, C. A., Williams, A. P., Lutz, J. A., \& Smith, A. M. S. (2017). Climatic influences on interannual variability in regional burn severity across western US forests. International Journal of Wildland Fire, 26(4), 269-275. https://doi.org/10.1071/WF16165

Agee, J. K. (1993). Fire Ecology of Pacific Northwest Forests. Washington, D.C.: Island Publisher.

Agee, J. K. (2002). The Fallacy of Passive Management Managing for Firesafe Forest Reserves. Conservation in Practice, 3(1), 18-26. https://doi.org/10.1111/j.1526-4629.2002.tb00023.x

Agee, J. K., \& Skinner, C. N. (2005). Basic principles of forest fuel reduction treatments. Forest Ecology and Management, 211(1-2), 83-96. https://doi.org/10.1016/j.foreco.2005.01.034

Albright, H. M., \& Schenck, M. A. (1999). Creating the National Park Service: The Missing Years. Norman. University of Oklahoma Press.

Allen, C. D., Macalady, A. K., Chenchouni, H., Bachelet, D., McDowell, N., Vennetier, M., ... Cobb, N. (2010). A global overview of drought and heat-induced tree mortality reveals emerging climate change risks for forests. Forest Ecology and Management, 259(4), 660-684. https://doi.org/10.1016/j.foreco.2009.09.001

Anderson, M. K., \& Morrato, M. J. (1996). Native American Land-Use Practices and Ecological Impacts. In Sierra Nevada Ecosystem Project: Final report to Congress, Volume II (Vol. II, pp. 187-206).

Arno, S. F., \& Allison-Bunnell, S. (2000). Flames in Our Forest: Distaster or Renewal? (2nd ed.). Island Press.

Bean, M. J. (2009). The endangered species act: Science, policy, and politics. Annals of the New York Academy of Sciences, 1162, 369-391. https://doi.org/10.1111/j.1749-6632.2009.04150.x

Benda, L. E., Litschert, S. E., Reeves, G. H., \& Pabst, R. (2016). Thinning and in-stream wood recruitment in riparian second growth forests in coastal Oregon and the use of buffers and tree tipping as mitigation. Journal of Forestry Research, 27(4), 821-836. https://doi.org/10.1007/s11676-0150173-2

Bentz, B. J., Regniere, J., Fettig, C. J., Hansen, E. M., Hayes, J. L., Hicke, J. A., ... Seybold, S. J. (2010). Climate Change and Bark Beetles of the Western United States and Canada: Direct and Indirect Effects. Bioscience, 60(8), 602-613. https://doi.org/10.1525/bio.2010.60.8.6

Berner, L. T., Law, B. E., Meddens, A. J. H., \& Hicke, J. A. (2017). Tree mortality from fires, bark beetles, and timber harvest during a hot and dry decade in the western United States (2003-2012). Environemental Research Letters, 12(6). https://doi.org/10.1088/1748-9326/aa6f94

Biswell, H. H. (1960). Danger of wildfires reduced by prescribed burning in ponderosa pine. Calfornia Agriculture, 14(10), 5-6.

Bonnet, V. H., Schoettle, a W., \& Shepperd, W. D. (2005). Postfire environmental conditions influence the spatial pattern of regeneration for Pinus ponderosa. Canadian Journal of Forest Research, 35, 37-47. https://doi.org/10.1139/X04-157

Boyd, R. (1999). Indians, Fire, and the Land in the Pacific Northwest. Oregon State Unversity Press.

Brown, J. K., \& Smith, J. K. (2000). Wildland Fire in Ecosystems: Effects of Fire on Flora. General Technical Report RMRS-GTR-42; U.S. Department of Agriculture, Forest Service, Rocky Mountain Research (Vol. 2). Ogden, UT, USA.

Butler, B. J. (2012). Forest Ownership Patterns. In Urban-Rural Interfaces: Linking People and Nature (pp. 117-125). https://doi.org/10.2136/2012.urban-rural.c7

Calkin, D., Katuwahl, H., Hand, M., \& Holmes, T. (2014). The effectiveness of suppression resources in large fire management in the US: a review. In Advances in forest fire research (pp. 1548-1552). Imprensa da Universidade de Coimbra. https://doi.org/10.14195/978-989-26-0884-6_170

Cannell, M. G. R. (1999). Environmental impacts of forest monocultures: water use, acidification, wildlife conservation, and carbon storage. New Forests, 17(1), 239-262. https://doi.org/10.1007/978-3540-32730-1_19

Chapman, H. H. (1932). Is the Longleaf Type a Climax? Ecology, 13(4), 328-334. 
Chiang, C. Y., \& Reese, M. (n.d.). II. Seeing the Forest for the Trees: Placing Washington's Forests in Historical Context.

Chmura, D. J., Anderson, P. D., Howe, G. T., Harrington, C. A., Halofsky, J. E., Peterson, D. L., ... Brad St.Clair, J. (2011). Forest responses to climate change in the northwestern United States: Ecophysiological foundations for adaptive management. Forest Ecology and Management, 261(7), 1121-1142. https://doi.org/10.1016/j.foreco.2010.12.040

Christensen, G. A., Campbell, S. J., Fried, J. S., \& Editors, T. (2008). California 's Forest Resources , 2001 - 2005 Five-Year Forest Inventory. Gen. Tech. Rep. PNW-GTR-763. https://doi.org/00000

Christianson, A. (2015). Social science research on indigenous wildfire management in the 21st Century and future research needs. International Journal of Wildland Fire, 24(2), 190-200. https://doi.org/10.1071/WF13048

Churchill, D. J., Larson, A. J., Dahlgreen, M. C., Franklin, J. F., Hessburg, P. F., \& Lutz, J. A. (2013). Restoring forest resilience: From reference spatial patterns to silvicultural prescriptions and monitoring. Forest Ecology and Management, 291, 442-457. https://doi.org/10.1016/j.foreco.2012.11.007

Clark, J. S., Iverson, L. R., Woodall, C. W., Allen, C. D., Bell, D. M., Bragg, D. C., ... Zimmermann, N. E. (2016). The impacts of increasing drought on forest dynamics, structure, and biodiversity in the United States. Global Change Biology, 22(7), 2329-2352. https://doi.org/10.1111/gcb.13160

Collins, B. M., \& Roller, G. B. (2013). Early forest dynamics in stand-replacing fire patches in the northern Sierra Nevada, California, USA. Landscape Ecology, 28(9), 1801-1813. https://doi.org/10.1007/s10980-013-9923-8

Cooper, C. F. (2006). Pattern in Ponderosa Pine Forests. Ecology, 42(3), 493-499. https://doi.org/10.2307/1932235

Cortner, H. J., Shannon, M. A., Wallace, M. G., Burke, S., \& Moote, M. A. (1996). Institutional barriers and incentives for ecosystem management: a problem analysis. Agriculture. https://doi.org/10.2737/PNW-GTR-354

Covington, W. W. (2000). Helping western forests heal. Nature, 408(6809), 135-136. https://doi.org/10.1038/35041641

Cox, T. R. (1974). Mills and Markets: A History of the Pacific Coast Lumber Industry to 1900. Univeristy of Washingon Press.

Dale, L. (2006). Wildfire policy and fire use on public lands in the United States. Society and Natural Resources, 19(3), 275-284. https://doi.org/10.1080/08941920500460898

DellaSala, D. A., Baker, R., Heiken, D., Frissell, C. A., Karr, J. R., Kim Nelson, S., ... Strittholt, J. (2015). Building on two decades of ecosystem management and biodiversity conservation under the Northwest Forest Plan, USA. Forests, 6(9), 3326-3352. https://doi.org/10.3390/f6093326

Dillon, G. K., Holden, Z. A., Morgan, P., Crimmins, M., Heyerdahl, E. K., \& Luce, C. H. (2011). Both topography and climate affected forest and woodland burn severity in two regions of the western US, 1984 to 2006. Ecosphere, 2(12), 1-33. https://doi.org/10.1890/ES11-00271.1

Donato, D. C., Fontaine, J. B., Campbell, J. L., Robinson, W. D., Kauffman, J. B., \& Law, B. E. (2009). Conifer regeneration in stand-replacement portions of a large mixed-severity wildfire in the Klamath-Siskiyou Mountains. Canadian Journal of Forest Research, 39(4), 823-838. https://doi.org/10.1139/X09-016

Dumont, C. W. (1996). The Demise of Community and Ecology in the Pacific Northwest: Historical Roots of the Ancient Forest Conflict. Sociolgoical Perspectives, 39(2), 277-300.

Edmonds, R. L., Agee, J. K., \& Gara, R. I. (2011). Forest Health and Protection. (2nd ed.). Waveland Prees, Inc.

Eldorado National Forest. (2014). Power Fire Reforestation Project.

Erickson, A., \& Rinehart, J. (2005). Private forest landownership in Washington State. In Saving Washington's Working Forest Land Base (p. 16). Retrieved from http://www.nwenvironmentalforum.org/documents/SciencePapers/tp1.pdf 
Fettig, C. J., Klepzig, K. D., Billings, R. F., Munson, A. S., Nebeker, T. E., Negrón, J. F., \& Nowak, J. T. (2007). The effectiveness of vegetation management practices for prevention and control of bark beetle infestations in coniferous forests of the western and southern United States. Forest Ecology and Management, 238(1-3), 24-53. https://doi.org/10.1016/j.foreco.2006.10.011

Finney, M. A. (2001). Design of regular landscape fuel treatment patterns for modifying fire growth and behavior. Forest Science, 47(2), 219-228.

Franklin, A. B., \& Gutierres, R. J. (2002). Spotted owls, forest fragmentation, and forest heterogeneity. In Effects of Habitat Fragmentation on Birds in Western Landscapes: Contrasts with Paradigms from the Eastern United States (pp. 203-220). Camarillo: Cooper Ornithological Society.

Franklin, J. F., Cromack, K., Denison, W., Mckee, A., Maser, C., Sedell, J., ... Juday, G. (1981). Ecological Characteristics of Old-Growth Douglas-Fir Forests.

Franklin, J. F., \& Forman, R. T. T. (1987). Creating landscape patterns by forest cutting: Ecological consequences and principles. Landscape Ecology, 1(1), 5-18. https://doi.org/10.1007/BF02275261

Franklin, J. F., \& Johnson, K. N. (2012). A Restoration Framework for Federal Forests in the Pacific Northwest. Journal of Forestry, 110(December), 429-439. https://doi.org/http://dx.doi.org/10.5849/jof.10-006

Franklin, J. F., Spies, T. A., Van Pelt, R., Carey, A. B., Thornburgh, D. A., Berg, D. R., ... Chen, J. (2002). Disturbances and structural development of natural forest ecosystems with silvicultural implications, using Douglas-fir forests as an example. Forest Ecology and Management, 155, 399423. https://doi.org/10.1016/S0378-1127(01)00575-8

Gedalof, Z., Peterson, D. L., \& Mantua, N. J. (2005). Atmospheric, climatic, and ecological controls on extreme wildfire years in the Northwestern United States. Ecological Applications, 15(1), 154-174. https://doi.org/10.1890/03-5116

Glasser, S. P. (2005). History of watershed management in the US Forest Service: 1897-2005. Journal of Forestry, 103(5), 255-258.

Hackel, S. W. (2012). From Ahogado to Zorrillo: External causes of mortality in the California missions. History of the Family, 17(1), 77-104. https://doi.org/10.1080/1081602X.2012.662012

Hanson, C. T., \& Odion, D. C. (2014). Is fire severity increasing in the Sierra Nevada, California, USA? International Journal of Wildland Fire, 23(1), 1. https://doi.org/10.1071/WF13016

Harris, L., \& Taylor, A. H. (2015). Topography, Fuels, and Fire Exclusion Drive Fire Severity of the Rim Fire in an Old-Growth Mixed-Conifer Forest, Yosemite National Park, USA. Ecosystems, 18(7), 1192-1208. https://doi.org/10.1007/s10021-015-9890-9

Hartesveldt, R. J., Harvey, H. T., Shellhammer, H. S., \& Stecker, R. E. (1975). The Giant Sequoia of the Sierra Nevada. Washington, D.C.: U.S. Department of the Interior National Park Service.

Hejl, S. J., Huno, R. L., Preston, C. R., \& Finch, D. M. (1995). Effects of Silviculture Treatments in the Rocky Mountains. Ecology and Management of Neotropical Migratory Birds, (1943), 220-244.

Hessburg, P. F., \& Agee, J. K. (2003). An environmental narrative of Inland Northwest United States forests, 1800-2000. Forest Ecology and Management (Vol. 178). https://doi.org/10.1016/S03781127(03)00052-5

Hessburg, P. F., Agee, J. K., \& Franklin, J. F. (2005). Dry forests and wildland fires of the inland Northwest USA: Contrasting the landscape ecology of the pre-settlement and modern eras. Forest Ecology and Management, 211(1-2), 117-139. https://doi.org/10.1016/j.foreco.2005.02.016

Hessburg, P. F., Smith, B. G., Salter, R. B., Ottmar, R. D., \& Alvarado, E. (2000). Recent changes (1930s1990s) in spatial patterns of interior northwest forests, USA. Forest Ecology and Management, 136(1-3), 53-83. https://doi.org/10.1016/S0378-1127(99)00263-7

Hessburg, P. F., Spies, T. A., Perry, D. A., Skinner, C. N., Taylor, A. H., Brown, P. M., ... Riegel, G. (2016). Tamm Review: Management of mixed-severity fire regime forests in Oregon, Washington, and Northern California. Forest Ecology and Management, 366, 221-250. https://doi.org/10.1016/j.foreco.2016.01.034

Heumann, B. (2009). Controlled Burning: Is it Worth it? Retrieved from http://blog.nature.org/conservancy/2009/09/08/controlled-burning-is-it-worth-it/ 
Huffman, M. R. (2013). The many elements of traditional fire knowledge: Synthesis, classification, and aids to cross-cultural problem solving in firedependent systems around the world. Ecology and Society, 18(4). https://doi.org/10.5751/ES-05843-180403

IPCC. (2013). Climate Change 2013: The Physical Science Basis.

Johnson, J. F., Bengston, D. N., Fan, D. P., \& Nelson, K. C. (2006). U .S. Policy Response to the Fuels Management Problem: An Analysis of the Public Debate About the Healthy Forests Initiative and the Healthy Forests Restoration Act. USDA Forest Service Proceedings, 59-66.

Jones, G. M., Gutiérrez, R., Tempel, D. J., Whitmore, S. A., Berigan, W. J., \& Peery, M. Z. (2016). Megafires: an emerging threat to old-forest species. Frontiers in Ecology and the Environment, 14(6), 300-306. https://doi.org/10.1002/fee.1298

Knapp, E. E., Varner, J. M., Busse, M. D., Skinner, C. N., \& Shestak, C. J. (2011). Behaviour and effects of prescribed fire in masticated fuelbeds. International Journal of Wildland Fire, 20(8), 932-945. https://doi.org/10.1071/WF10110

Kobziar, L. N., Mcbride, J. R., \& Stephens, S. L. (2009). The efficacy of fire and fuels reduction treatments in a Sierra Nevada pine plantation. International Journal of Wildland Fire, 791-801.

Koch, E. (1935). The Passing of the Lolo Trail. Journal of Forestry, 33(2), 95-104. https://doi.org/10.1007/bf03400632

Kreye, J. K., Brewer, N. W., Morgan, P., Varner, J. M., Smith, A. M. S., Hoffman, C. M., \& Ottmar, R. D. (2014). Fire behavior in masticated fuels: A review. Forest Ecology and Management, 314, 193207. https://doi.org/10.1016/j.foreco.2013.11.035

Larson, A. J., \& Churchill, D. J. (2012). Tree spatial patterns in fire-frequent forests of western North America, including mechanisms of pattern formation and implications for designing fuel reduction and restoration treatments. Forest Ecology and Management, 267, 74-92. https://doi.org/10.1016/j.foreco.2011.11.038

Laudenslayer, W. F., \& Darr, H. H. (1990). Historical Effects of Logging on the Forests of the Cascade and Sierra Nevada. Transactions of the Western Section of the Wildlife Society.

Logan, J. A., Macfarlane, W. W., \& Louisa, W. (2010). Whitebark pine vulnerability to climate-driven mountain pine beetle disturbance in the Greater Yellowstone Ecosystem. Ecological Applications, 20(4), 895-902. https://doi.org/10.1890/09-0655.1

Lyons-Tinsley, C., \& Peterson, D. L. (2012). Surface fuel treatments in young, regenerating stands affect wildfire severity in a mixed conifer forest, eastside Cascade Range, Washington, USA. Forest Ecology and Management, 270, 117-125. https://doi.org/10.1016/j.foreco.2011.04.016

McDonald, P. M., \& Fiddler, G. O. (2010). Twenty-five years of managing vegetation in conifer plantations in northern and central California: results, application, principles, and challenges. Psw-Gtr-23, 188. Retrieved from http://www.srs.fs.usda.gov/pubs/37965

McGinnis, T. W., Keeley, J. E., Stephens, S. L., \& Roller, G. B. (2010). Fuel buildup and potential fire behavior after stand-replacing fires, logging fire-killed trees and herbicide shrub removal in Sierra Nevada forests. Forest Ecology and Management, 260(1), 22-35. https://doi.org/10.1016/j.foreco.2010.03.026

Meyer, M. D., \& Safford, H. D. (2011). Giant sequoia regeneration in grovesexposed to wildfire and retention harvest. Fire Ecology, 7(2), 2-16. https://doi.org/10.4996/fireecology.0702002

Millar, C. I., Stephenson, N. L., \& Stephens, S. L. (2007). Climate change and forests of the future: managing in the face of uncertainty. Ecological Applications, 17(8), 2145-2151.

Miller, C., \& Urban, D. L. (2000). Connectivity of forest fuels and surface fire regimes. Landscape Ecology, 15(2), 145-154. https://doi.org/10.1023/A:1008181313360

Miller, J. D., \& Safford, H. D. (2012). Trends in wildfire severity: 1984 to 2010 in the Sierra Nevada, Modoc Plateau, and southern Cascades, California, USA. Fire Ecology, 8(3), 41-57. https://doi.org/10.4996/fireecology.0803041

Miller, J. D., Safford, H. D., Crimmins, M., \& Thode, A. E. (2009). Quantitative evidence for increasing forest fire severity in the Sierra Nevada and southern Cascade Mountains, California and Nevada, USA. Ecosystems, 12(1), 16-32. https://doi.org/10.1007/s10021-008-9201-9 
Morgan, P., Hudak, A. T., Wells, A., Parks, S. A., Baggett, L. S., Bright, B. C., \& Green, P. (2017). Multidecadal trends in area burned with high severity in the Selway-Bitterroot Wilderness Area 1880-2012. International Journal of Wildland Fire, 26(11), 930-943. https://doi.org/10.1071/WF17023

Moritz, C., Patton, J. L., Conroy, C. J., Parra, J. L., White, G. C., \& Beissinger, S. R. (2008). Impact of a century of climate change on small mammal communities in Yosemite national park, USA. Science, 322(October), 261-264.

Naficy, C., Sala, A., Keeling, E. G., Graham, J., \& DeLuca, T. H. (2016). Interactive effects of historical logging and fire exclusion on contemporary structure of ponderosa pine/Douglas-fir forests of the Northern Rockies. Ecological Applications, 20(7), 1851-1864. https://doi.org/10.1890/09-0217.1

Nagel, T. A., \& Taylor, A. H. (2005). Fire and persistence of montane chaparral in mixed conifer forest landscapes in the northern Sierra Nevada, Lake Tahoe Basin, California , USA. Journal of the Torrey Botanical Society, 132(3), 442-457.

Neznek, R. (2004). Healthy Forests Initiative and Its Effect on Appeals. Journal of Forestry, (March), 5-7.

North, M. P. (2012). Managing Sierra Nevada forests. United States Department of Agriculture: Forest Service. Retrieved from http://www.srs.fs.usda.gov/pubs/40254

North, M. P., Stephens, S. L., Collins, B. M., Agee, J. K., Aplet, G. H., Franklin, J. F., \& Fulé, P. Z. (2015). Reform forest fire management. Science, 349(6254), 1280-1281. https://doi.org/10.1126/science.aab2356

North, M. P., Stevens, J. T., Greene, D. F., Coppoletta, M., Knapp, E. E., Latimer, A. M., ... Wyrsch, P. (2019). Tamm Review: Reforestation for resilience in dry western U.S. forests. Forest Ecology and Management, 432(July 2018), 209-224. https://doi.org/10.1016/j.foreco.2018.09.007

North, M. P., Stine, P. A., O’Hara, K., Zielinski, W. J., Stephens, S. L., Service, F., \& Hara, K. O. (2009). An ecosystem management strategy for Sierran mixed- conifer forests. USDA Forest Service, Pacific Southwest Research Station, General Technical Report.

Old-Growth Definition Task Group. (1986). Interim Definitions for Old-Growth Douglas Fir and Mixed Conifer Forests in the Pacific Northwest and California. Portland, OR, USA.

Perry, D. A., Hessburg, P. F., Skinner, C. N., Spies, T. A., Stephens, S. L., Taylor, A. H., ... Riegel, G. (2011). The ecology of mixed severity fire regimes in Washington, Oregon, and Northern

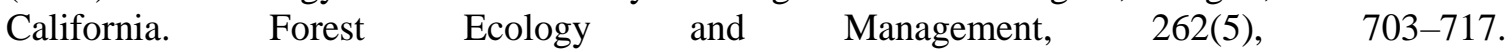
https://doi.org/10.1016/j.foreco.2011.05.004

Pyne, S. J. (1997). Fire in America: A Cultural History of Wildland and Rural Fire. Univeristy of Washingon Press.

Pyne, S. J. (2004). Tending Fire: Coping with America's Wildland Fores. Island Press.

Pyne, S. J. (2008). Year of the Fires: The Story of the Great Fires of 1910. Mountain Press Publishing Company.

Redeloff, V. C., Hammer, R. B., Stewart, S. I., Fried, J. S., Holcomb, S. S., \& McKeefry, J. F. (2005). The Wildland-Urban Interface in the United States. Ecological Applications, 15(3), 799-805.

Reiner, A. L., Vaillant, N. M., \& Dailey, S. N. (2012). Mastication and Prescribed Fire Influences on Tree Mortality and Predicted Fire Behavior in Ponderosa Pine. Journal of Applied Forestry, 27(1), 3641.

Reiner, A. L., Vaillant, N. M., Fites-Kaufman, J. A., \& Dailey, S. N. (2009). Mastication and prescribed fire impacts on fuels in a 25-year old ponderosa pine plantation, southern Sierra Nevada. Forest Ecology and Management, 258(11), 2365-2372. https://doi.org/10.1016/j.foreco.2009.07.050

Roose, H., Ballard, L., Manley, J., Saleen, N., \& Harbert, S. (2008). Fire Program Analysis System Preparedness Module 1. Proceedings of the Second International Symposium on Fire Economics, Planning, and Policy: A Global View, 377-384. Retrieved from http://www.frames.gov/rcs/9000/9308.html

Rothman, H. K. (2007). Blazing heritage: a history of wildland fi re in the National Parks. Oxfird Univeristy Press. 
Russell, W. H., Mcbride, J. R., \& Rowntree, R. (1998). Revegtation after four stand replacing fires in the Lake Tahoe Basin. Madrono, 45(1), 40-46.

Safford, H. D., Stevens, J. T., Merriam, K., Meyer, M. D., \& Latimer, A. M. (2012). Fuel treatment effectiveness in California yellow pine and mixed conifer forests. Forest Ecology and Management, 274, 17-28. https://doi.org/10.1016/j.foreco.2012.02.013

Schmidt, D. A., Taylor, A. H., \& Skinner, C. N. (2008). The influence of fuels treatment and landscape arrangement on simulated fire behavior, Southern Cascade range, California. Forest Ecology and Management, 255(8-9), 3170-3184. https://doi.org/10.1016/j.foreco.2008.01.023

Schoennagel, T., Balch, J. K., Brenkert-Smith, H., Dennison, P. E., Harvey, B. J., Krawchuk, M. A., ... Whitlock, C. (2017). Adapt to more wildfire in western North American forests as climate changes. Proceedings of the National Academy of Sciences, 114(18), 4582-4590. https://doi.org/10.1073/pnas.1617464114

Scott, A. C., Bowman, D. M. J. S., Bond, W. J., Pyne, S. J., \& Alexander, M. E. (2014). Fire on Earth: an introduction. Wiley Blackwell.

Skinner, C. N. (1995). Change in Spatial Characteristics of Forest Openings in the Klamath Mountians of Northwestern California, USA. Landscape Ecology, 10(4), 1995.

Spies, T. A., Stine, P. A., Gravenmier, R., Long, J. W., \& Reilly, M. J. (2018). Synthesis of Science to Inform Land Management Within the Northwest Forest Plan Area. Gen. Tech. Rep. PNWGTR_966, 1(June), 1020. Retrieved from https://www.fs.fed.us/pnw/research/sciencesynthesis/chapters/NWFP synthesis draft Ch1 for peer review 101916.pdf

Steelman, T. (2016). U.S. wildfire governance as social-ecological problem. Ecology and Society, 21(4). https://doi.org/10.5751/ES-08681-210403

Stephens, S. L. (2005). Forest fire causes and extent on United States Forest Service lands. International Journal of Wildland Fire, 14(3), 213-222. https://doi.org/10.1071/WF04006

Stephens, S. L., Agee, J. K., Fulé, P. Z., North, M. P., Romme, W. H., Swetnam, T. W., \& Turner, M. G. (2013). Managing forests and fire in changing climates. Science, 342(6154), 41-42. https://doi.org/10.1126/science.1240294

Stephens, S. L., Collins, B. M., Fettig, C. J., Finney, M. A., Hoffman, C. M., Knapp, E. E., ... Wayman, R. B. (2018). Drought, Tree Mortality, and Wildfire in Forests Adapted to Frequent Fire. BioScience, 68(2), 77-88. https://doi.org/10.1093/biosci/bix146

Stephens, S. L., Fry, D. L., \& Franco-Vizcaíno, E. (2008). Wildfire and forests in northwestern Mexico: the United States wishes it had similar fire problems. Ecology and Society, 13(2), 10.

Stephens, S. L., Miller, J. D., Collins, B. M., North, M. P., Keane, J. J., \& Roberts, S. L. (2016). Wildfire impacts on California spotted owl nesting habitat in the Sierra Nevada. Ecosphere, 7(11), e01478n/a. https://doi.org/10.1002/ecs2.1478

Stephens, S. L., \& Moghaddas, J. J. (2005). Experimental fuel treatment impacts on forest structure, potential fire behavior, and predicted tree mortality in a California mixed conifer forest. Forest Ecology and Management, 215(1-3), 21-36. https://doi.org/10.1016/j.foreco.2005.03.070

Stephens, S. L., \& Ruth, L. W. (2005). Federal Forest-Fire Policy in the United States. Ecological Applications, 15(2), 532-542.

Stephens, S. L., \& Wagner, M. R. (2007). Forest plantations and biodiversity: a fresh perspective. Journal of Forestry, 105(September), 307-313. Retrieved from http://www.ingentaconnect.com/content/saf/jof/2007/00000105/00000006/art00012

Stine, P. A., Hessburg, P. F., Spies, T. A., Kramer, M., Fettig, C. J., Hansen, A., ... White, R. (2013). The ecology and management of moist mixed-conifer forests in eastern Oregon and Washington, a synthesis of the relevant science and implications for future land management. USDA Forest Service General Technical Report, Pacific Northwest. PNW-GTR-897, (September).

Stoddard, H. L. (1931). The bobwhite quail: its habits, preservation and increase. New York, NY: Charles Scribner's Sons. 
Suzuki, N., \& Olson, D. H. (2008). Options for biodiversity conservation in managed forest landscapes of multiple ownerships in Oregon and Washington, USA. Biodiversity and Conservation, 17(5), 1017-1039. https://doi.org/10.1007/s10531-007-9301-4

Swanson, F., \& Franklin, J. F. (1992). New Forestry Principles from Ecosystem Analysis of Pacific Northwest Forests. Ecological Applications, 2(3), 262-274.

Swetnam, T. W., Allen, C. D., \& Betancourt, J. L. (1999). Applied Historical Ecology: Using the Past to Manage for the Future. Ecological Applications, 9(4), 1189-1206.

Tappeiner, J. C., Maguire, D. A., Harrington, T. B., \& Bailey, J. D. (2015). Silviculture and Ecology of Western U.S. Forests (Second). Corvallis: Oregon State Unversity Press.

Tappeiner, J. C., \& McDonald, P. M. (1996). Regeneration of Sierra Nevada forests. Sierra Nevada Ecosystem Project Final Report to Congress: Status of the Sierra Nevada, 3, 501-513.

Taylor, A. H., Trouet, V., Skinner, C. N., \& Stephens, S. L. (2016). Socioecological transitions trigger fire regime shifts and modulate fire-climate interactions in the Sierra Nevada, USA, 1600-2015 CE. Proceedings of the National Academy of Sciences, 113(48), 13684-13689. https://doi.org/10.1073/pnas.1609775113

Turner, M. G. (2010). Disturbance and landscape dynamics in a changing world. Ecology, 91(10), 28332849.

U.S. Department of Agriculture (USDA) Forest Service. (2010). National Report on Sustainable Forests 2010.

U.S. Department of the Interior, \& U.S. Department of Agriculture. (1995). Federal Wildland Fire Management Final Report.

U.S. Department of the Interior, U.S. Department of Agriculture, Jewell, S., \& Vilsack, T. J. (2014). The National Strategy; The Final Phase in the Development of the National Cohesive Wildland Fire Management Stragety.

U.S. Department of the Interior, \& USDA Forest Service. (2002). National Fire Plan. Retrieved from https://www.fs.fed.us/database/budgetoffice/NFP_final32601.pdf

US FWS (Fish and Wildlife Service). (2014). Fire Management. Retrieved from https://www.fws.gov/fire/who_we_are/history.shtml

USDA Forest Service. (2004). Record of Decision. Sierra Nevada Forest Plan Amendment - Final Supplemental Environmental Impact Statement, 72. Retrieved from http://www.fs.usda.gov/detail/r5/landmanagement/planning/?cid=STELPRDB5349922

Van Wagtendonk, J. W. (2007). The history and evolution of wildland fire use. Fire Ecology, 3(2), 3-17. https://doi.org/10.4996/fireecology.0302003

Vose, J. M., Peterson, D. L., Domke, G. M., Fettig, C. J., Joyce, L., Keane, R. E., ... Prestemon, J. P. (2018). Forests. (G. Marland, Ed.), Impacts, Risks, and Adaptation in the United States: Fourth National Climate Assessment, Volume II (Vol. II). Washington, DC. https://doi.org/10.7930/NCA4.2018.CH6

Weaver, H. (1952). A Preliminary Report on Prescribed Burning in Virgin Ponderosa. Journal of Forestry, 50(9), 662-667.

Welch, K. R., Safford, H. D., \& Young., T. P. (2016). Predicting conifer establishment 5-7 years after wildfire in middle elevation yellow pine and mixed conifer forests of the North American Mediterranean-climate zone. Ecosphere, in press(December). https://doi.org/10.1002/ecs2.1609

Westerling, A. L., \& Bryant, B. P. (2007). Climate change and wildfire in California. Climatic Change, 87(1 SUPPL). https://doi.org/10.1007/s10584-007-9363-z

Westerling, A. L., Hidalgo, H. G., Cayan, D. R., \& Swetnam, T. W. (2006). Warming and earlier spring increase western U.S. forest wildfire activity. Science, 313(5789), 940-943. https://doi.org/10.1126/science.1128834

Yoder, J., Engle, D., \& Fuhlendorf, S. (2004). Liability , Incentives , and Prescribed Fire for Ecosystem Management. Frontiers in Ecology and the Environment, 2(7), 361-366. 
Zald, H. S. J., \& Dunn, C. J. (2018). Severe fire weather and intensive forest management increase fire severity in a multi-ownership landscape. Ecological Applications, 28(4), 1068-1080. https://doi.org/10.1002/eap.1710

Zhang, J., Webster, J., Powers, R. F., \& Mills, J. (2008). Reforestation after the Fountain Fire in Northern California: An Untold Success Story. Journal of Forestry, 106(8), 425-430. 


\subsection{Figures and Tables}

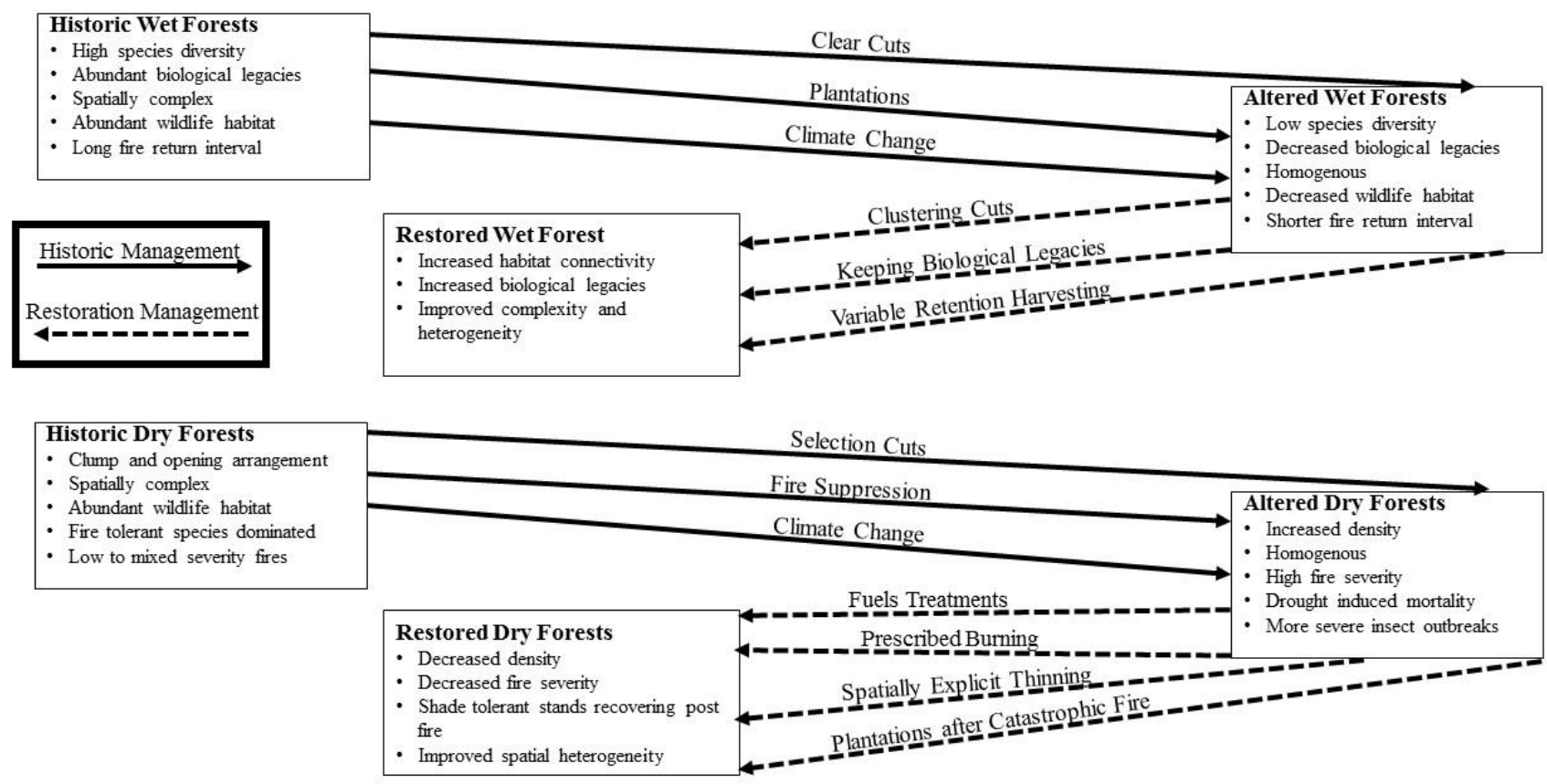

Historical Conditions

Heavily Altered

Figure 1. Effects of historic and restoration management on the wet and dry forests of the northwestern United States and California. 


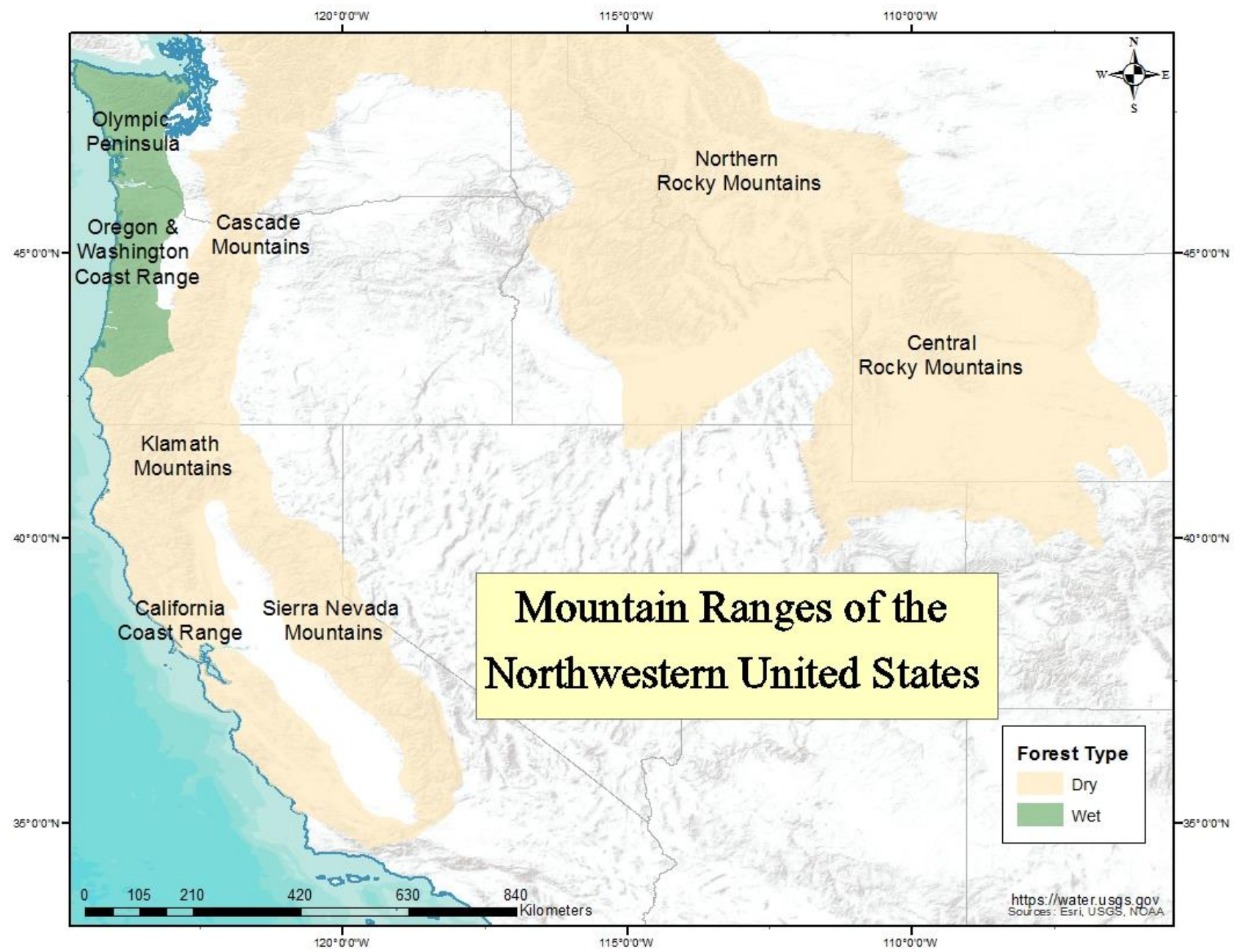

Figure 2. Map of mountain ranges of the northwestern United States and California showing the distribution of wet and dry forest types. Data usgs.gov 


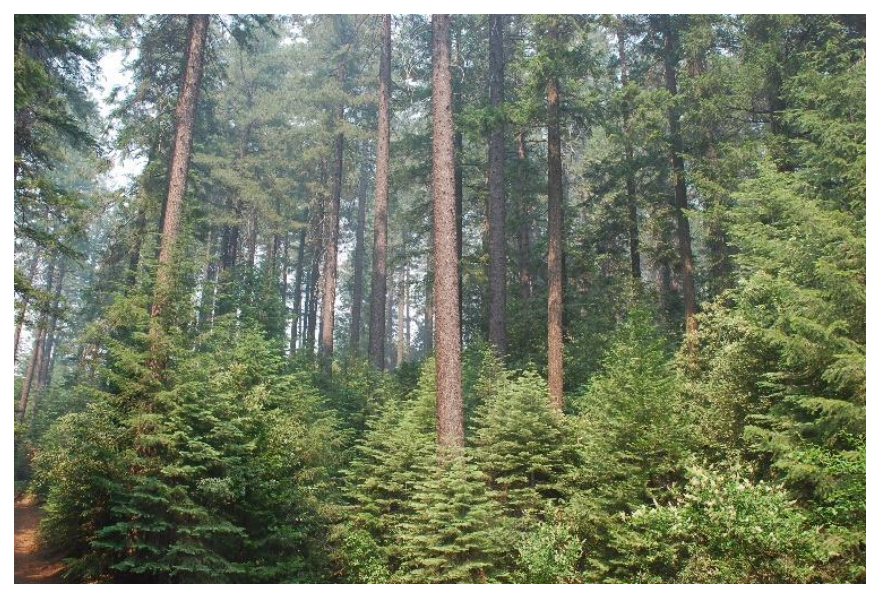

Figure 3. A fire-suppressed mixed-conifer stand in the Sierra Nevada region of northern California. The overstory is dominated by sugar pine and ponderosa pine. The stand contains a dense understory of shade tolerant, fire sensitive white fir, and incense cedar. Photo Credits: Dr. Jianwei Zhang, 2008

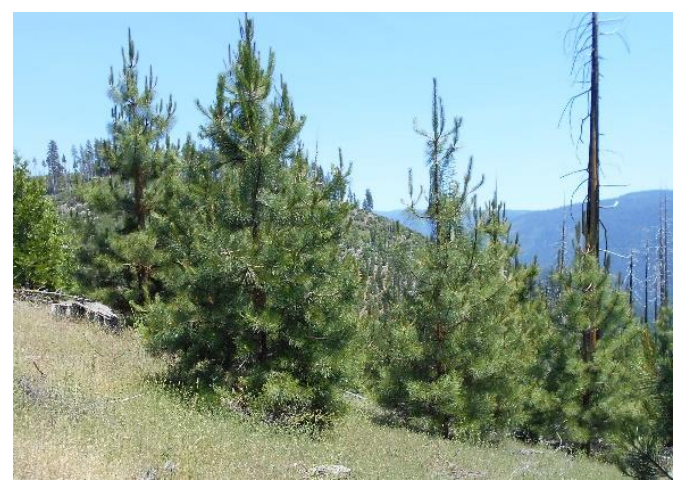

(a)

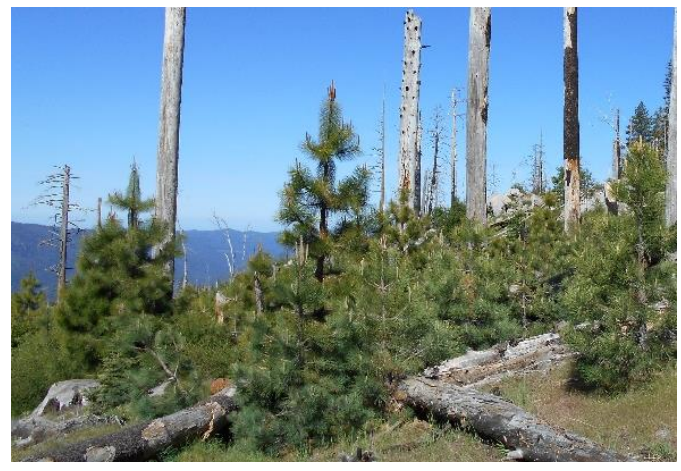

(b)

Figure 4. Comparison of a traditional, evenly spaced plantation (a), and a novel clustered arrangement (b) in the mixed-conifer forest region of the Sierra Nevada, Eldorado National Forest. Photo Credits: Iris Allen, 2017 


\section{Chapter 2: Comparing past growth and ecology between two plantation arrangements and natural regenerating stands after a high severity fire}

\subsection{Introduction}

Climate change, past logging practices, and over a century of fire suppression has caused a change in the fire regime of mixed conifer forest in the Sierra Nevada (Agee, 1993; Miller and Safford, 2012; Westerling and Bryant, 2007). The contemporary fires leave the landscape heavily altered, disrupting the post-fire successional process by limited conifer regeneration. Shrubs will often dominate this post fire landscape due to their persistent soil seed bank (Nagel and Taylor, 2005). Shrubs can outcompete the conifer seedlings for light and water, delaying conifer regeneration for decades (Russell et al., 1998). In addition to increased competition, stand replacing fires kill seed source trees, preventing the establishment of the next generation of trees (Bonnet et al., 2005). To aid with reforestation, plantations are often established after stand replacing fires, and are usually more successful than natural regenerating stands (Collins and Roller, 2013; North et al., 2019). These post-fire restoration plantations require intensive shrub management to be successful (McDonald and Fiddler, 2010; Zhang et al., 2006). They also face a large fire risk due to their close, even spacing and high amount of ladder fuels (Kobziar et al., 2009; North et al., 2019).

While most plantations are evenly spaced, some restoration projects plant them in small aggregates, usually of two to four trees (Eldorado National Forest, 2014; North et al., 2019). This is an attempt to mimic the natural clumping pattern of historically fire resilient Sierra Nevada forests (Churchill et al., 2013; North et al., 2009). A potential drawback to this method is that it could increase competition between the trees, impacting growth and survival (Duchesneau et al., 2001). Light is one of the most important factors for tree regeneration in mixed conifer forests (McDonald, 1976). Increasing light and soil moisture competition within clumped plantings could be detrimental to seedling survival, as they are important factors for mixed conifer seedling growth and survival (Royce and Barbour, 2001; Tappeiner and McDonald, 1996). However, a mutual benefit (facilitation) of young trees within a clump has been 
observed before (Fajardo and McIntire, 2011; Owen et al., 2017). facilitation could result from neighboring trees shading each other and improving soil moisture, benefitting growth in dry conditions (Holmgren, 2000). Also, ectomycorrhizal connections between trees are stronger at closer distances (Simard, 2009). The literature on clustered plantations in the United States is scarce, with no published studies on it in the Sierra Nevada to my knowledge. It is important to quantify the advantages and disadvantages of clustered plantations if they are to be used as a regeneration method in post fire restoration.

This chapter focuses on early forest dynamics in two types of mixed conifer plantations after a high severity fire: one planted in the traditional, evenly-spaced method, and one with trees planted in clusters. Specifically, the objective of this study is to quantify growth and ecological differences using regression-based modeling between these two plantations types along with how they compare to naturally regenerating stands after a fire.

\subsection{Methods}

\subsubsection{Study Area}

My study took place in the boundary of the 2004 Power Fire that burned at the southern extent of the Eldorado National Forest, which lies in the north-central Sierra Nevada Mountains of California (Fig. 1). These mountains are in a Mediterranean climate, with dry, warm summers and cool, wet winters (Bailey, 2016). Most of the precipitation falls as snow from October to April, averaging about $130 \mathrm{~cm}$ throughout the year. Mean daily temperature ranges from $-6.4{ }^{\circ} \mathrm{C}$ in January to $22.5^{\circ} \mathrm{C}$ in August (PRISM Climate Group, http://prism.oregonstate.edu, Accessed 6 March 2019). The soils are primarily Jocal loam in the western portion and vary in the eastern portion, but with large area compromised of Chaix-Pilliken coarse sandy loam and Windy gravelly sandy loam (Natural Resource Conservation Service, 2018). The study site ranges from 1300 to $2000 \mathrm{~m}$ in elevation, in the mid-range of the mountains. The dominant forest type is mixed conifer, which consists of ponderosa pine (Pinus ponderosa Lawson \& C. Lawson), Jeffery pine (Pinus jefferyi Grev. \& Balf.), sugar pine (Pinus 
lambertina Douglas), Douglas-fir (Pseudotsuga menziesii (Mrib.) Franco), incense cedar (Calocedrus decurrens (Torr.) Florin), white fir (Abies concolor (Gord. \& Glend.) Lindl. ex Hildebr.), red fir (Abies magnifica A. Murr.), and giant sequoia (Sequoiadendron giganteum (Lindl.)Buchholz). Jeffrey pine and red fir are more common at higher elevations (Fites-Kaufman et al., 2007).

The Power Fire burned 6,000 hectares, with almost 50\% of the fire burning at high severity, corresponding to more than $75 \%$ tree mortality (Hann et al., 2008). In efforts to restore the burned area, the Forest Service established plantations from 2005 to 2009 (Fig. 2) (U.S. Department of Agriculture (USDA) Forest Service, 2017). They planted ponderosa pine, Jeffery pine, sugar pine, Douglas-fir, incense cedar, white fir, red fir, and giant sequoia, with ponderosa pine being the most predominate. Two planting arrangements were used, each attempting to attain different goals designated by the Sierra Nevada Forest Plan Amendment Record of Decision (USDA Forest Service, 2004). The clustered planting arrangement, or planting group A, mimics historical group-gap forest structure. It is composed of aggregates of 2-4 trees, with about $6.4 \mathrm{~m}$ between clusters and $1 \mathrm{~m}$ between trees in the cluster for a final planting density of 494 to 988 trees per hectare. On the other hand, the evenly spaced arrangement, or planting group B, follows a traditional silvicultural planting scheme with even spacing and is intended to create dense habitat for the endangered northern spotted owl. Trees were planted evenly with about $4 \mathrm{~m}$ inter-tree spacing, a planting density of 741 to 865 trees per hectare. About $75 \%$ of all plantations were pre-commercially thinned (PCT) from 2013-2015. This thinning was performed on trees and shrubs, with slash left unmulched on the ground.

\subsubsection{Site Selection}

I selected sites to represent conditions in both planting arrangements and in adjacent noplantation forest land (Fig. 2). Field sampling occurred from May to August in 2017. I identified clustered and evenly spaced plantations without interplanting after initial establishment that occurred in moderate to high severity burned areas covering similar areas. Stands covered a range of slopes and aspects. I verified stand selection in the field and sites with plantation failure (i.e. conversion to shrub fields) were eliminated since the goal of this study was to evaluate how established plantations performed, not identify 
the factors that cause a plantation to succeed. Elevation at thinned sites ranged from 1340 to $1570 \mathrm{~m}$ and from 1940 to $2000 \mathrm{~m}$ at the unthinned sites. Pre-commercial thinning was only performed at lower elevations because the high elevation plantations had not reached an adequate size for thinning. This resulted in a confounding factor between thinning and elevation which was accounted for and addressed in data analysis and discussion. I selected ten plantations: three clustered-thinned, three evenly spacedthinned, two clustered-not thinned, and two evenly spaced-not thinned (Fig. 2, Tables $1 \& 2$ ). I located natural regenerating stands in areas without management that 1) burned at moderate to high severity and 2) were within 1 mile of sampled plantations. I field-verified the stands to ensure trees established after the fire, i.e. after 2004. I selected four naturally regenerating stands, two near the unthinned plantations and two near the thinned plantations (Fig. 2, Tables $1 \& 2$ ).

To determine plot locations within a particular stand, I digitally imposed a 50 by $50 \mathrm{~m}$ grid over each stand, with a 20-m buffer zone at stand boundaries. I randomly selected five intersections from each grid as plot locations. If an intersection landed in an area that could not be sampled (i.e. too steep for safe access, road intersecting) I selected another random point until there were a total of five plots per stand. Each plot was circular and $200 \mathrm{~m}^{2}$ (1/50 hectare, $7.98 \mathrm{~m}$ radius) in area (Fig. 3). All stands had five plots except for two natural regenerating stands, one with seven plots and one with eight plots. This was done so that clustered, evenly spaced, and natural regenerating stands would each have 25 total plots total.

\subsubsection{Field Methods}

My field team inventoried forest structure to quantify stand growth and attributes. At each plot, we took pictures from the center facing the cardinal directions (north, east, south, west), and recorded slope, and aspect. For all trees taller than breast height $(1.37 \mathrm{~m})$ (assumed to be planted) within the plot, we collected species, DBH, and status (live/dead). We randomly selected a subset of five yellow pines (ponderosa or Jeffery pine) to collect additional measurements, specifically height, crown width in two directions, height to live crown, and interwhorl height using an ultrasonic measurement system; furthermore, we cored these pines at breast height using an increment borer to determine basal area increment. Pines are the only species in this forest type that grows one distinct whorl each year, allowing 
the collection of annual interwhorl measurements. Within the half plot radius, we recorded species and heights for all trees below breast height (referred to as regeneration) (Fig. 3). We identified all stumps from after the thinning (i.e. similar diameter as standing trees, no char) within the thinned plots, and recorded stump diameter and height.

We surveyed understory vegetation using a $1 \mathrm{~m}$ x $1 \mathrm{~m}$ ground cover plot centered at half way points $(3.99 \mathrm{~m})$ along the northeast and southwest radii of each plot (Fig. 3). We estimated percent cover of the different herbaceous species along with a count of individual plants per species. Within in halfradius plot, we recorded shrub species, height, and two perpendicular crown diameters (Fig. 3). If a shrub extended past the half radius boundary, we only measured the diameter portion within the half-radius boundary. We recorded distance to nearest seed source (mature, cone baring) with a laser range finder for the following tree species: ponderosa pine, Jeffrey pine, white fir, red fir, incense cedar, and Douglas-fir.

\subsubsection{Laboratory Methods}

I used standard dendrochronological methods to determine past tree growth. I left cores collected in the field to dry for at least a month before I mounted and sanded them to 600 grit. Due to the very short chronologies (most cores ranged from seven to three rings) and robust growth rings, I only visually crossdated and not statistically crossdated the cores. I scanned the cores at 2400 dpi and measured the ring widths of the images with the software program CooRecorder 9.0 (Cybis Electronic, 2018). I converted rings widths to annual basal area increment $\left(\mathrm{BAI}, \mathrm{mm}^{2}\right)$ using the dplR dendrochronology package in $\mathrm{R}$ (Bunn, 2008).

\subsubsection{Statistical Methods}

Statistical analyses were conducted to determine differences between the two planting arrangements and naturally regenerating stands. I conducted two types of data analysis, analysis of variance (ANOVA), and multiple linear regression. Three mixed-effect ANOVAs were performed: 1) one-way ANOVA comparing all five different treatment categories (clustered-thinned, evenly spacedthinned, clustered-not thinned, evenly spaced-not thinned, and natural regeneration); 2) two-way ANOVAs on just the plantations using planting arrangement and presence of thinning as the two 
treatment factors; 3) t-tests comparing thinned plantations by planting arrangement: clustered and evenly spaced.

For the one-way and two-way ANOVAs I tested the following growth/density variables: BAI before thinning, annual height growth before thinning, diameter at breast height, total height, trees per hectare before thinning, and trees per hectare after thinning, and density of trees below breast height (regeneration). I also tested the following ecological variables: shrub height, percent of plot covered in shrubs, species richness, and Shannon's diversity index $\left(\sum_{i=1}^{s} p_{i} \times \ln p_{i} ; s=\right.$ total number of species, $p_{i}=$ proportion of individuals in species $i$ ). I tested the following variables among only the thinned plantations: BAI after thinning, height growth after thinning, and two growth indices (referred to as "thinning index"), one for BAI and one for height using the following equation:

$\left(\frac{\text { growth after thinning-growth before thinning }}{\text { growth before thinning }}\right)$ I calculated this to determine the percent change from before thinning to after thinning growth.

Thinning occurred in 2015, and sampling occurred in 2017, therefore, pre or before thinning refers to growth in 2013 and 2014 and after or post thinning refers to growth in 2016. I used Plantation ID as a random effect if the tested dependent variable was measured at the plot level (e.g. plot area covered by shrub, trees per hectare); I used plot ID nested inside plantation ID as a random effect if I measured the variable at the individual level (e.g. DBH, shrub height). Additionally, I nested plantation ID inside planting and thinning treatment. I tested normality using the Shapiro-Wilk test. If any tests were not normal, I performed transformations, including natural logarithm and square root transformations, until normality was achieved (Tables $3 \& 4$ ). I used Tukey's HSD for all Post hoc tests. I ran all ANOVAs as mixed effects models using the JMP V.14.0.0 statistical program (SAS Institute Inc., 2018).

I set up the multiple linear regression models similarly to the ANOVAs, except that all models used data summarized at the plot level and I ran them using the R Studio interface of the R statistical program (RStudio Team, 2018). There were two different models for each dependent variable. One included all treatments (clustered-thinned, evenly spaced-thinned, clustered-not thinned, evenly spaced- 
not thinned, and natural regeneration), and had treatment as a categorical, explanatory variable. The other only used plantations and had plantation arrangement (clustered or evenly spaced) and thinning (yes of no) as categorical, explanatory variables. In addition to the categorical variables, I used the following continuous, explanatory variables: elevation, aspect, slope, percent shrub cover, average shrub height, Shannon's diversity index, species richness, trees per hectare, density of tree regeneration, the distance to the closest seed source, and the proportion of trees that were yellow pines in each plot. The dependent variables modeled were BAI before thinning, BAI after thinning, annual height growth before thinning, and annual height growth after thinning. I used the stepAIC function in R, an AIC stepwise model selection process to determine model variables. After stepwise regression selected a model, I removed all non-significant variables resulting in the final model.

\subsection{Results}

\subsubsection{One-Way ANOVA}

Growth in the unthinned plantations resembled that of the natural regenerating stands, which was lower than growth of the thinned plantations. Average BAI before thinning differed between the five treatments $(\mathrm{F}=8.5649, \mathrm{p}=0.0018)$. The natural regenerating stands had $80 \%$ less BAI before thinning than the thinned plantations but were not different from the unthinned plantations (Fig. 4, Table 3). There were similar results for average height growth before thinning $(F=37.5876, p<0.0001)$, total tree height $(\mathrm{F}=35.2145, \mathrm{p}<0.0001)$, and DBH $(\mathrm{F}=25.7876, \mathrm{p}<0.0001)($ Figs. $4 \& 5$, Table 3). The different treatments were similar in terms of shrub cover and understory species diversity. I did not find any differences in mean species richness, Shannon's diversity, density of regeneration, trees per hectare after thinning (Fig. 6), and percent of the plot covered in shrubs (all p >0.1, Table 3) However, there was a trend of average shrub height differing among the treatments $(F=3.5124, p=0.0517)$. The natural regenerating stands tended to have shrubs $50 \%$ shorter than the other treatments (Fig. 7, Table 3). I tried to test for difference in tree basal area per hectare between treatments but could not meet the normality assumption of the model despite trying multiple different transformations. 


\subsubsection{Two -Way ANOVA}

With the exception of diameter growth, I found no differences between the clustered and evenly spaced planting arrangements. Average BAI before thinning, differed between the two planting arrangements $(\mathrm{F}=4.9394, \mathrm{p}=0.0427)$ with the clustered plantation growing $35 \%$ more than the evenly spaced plantations (Fig. 8, Table 4). This model also had a significant thinning effect $(\mathrm{F}=19.3637, \mathrm{p}=$ 0.0006). The growth variables diameter at breast height, annual height growth before thinning, total height, and basal area per hectare differed among thinning, but not plantation arrangement (Table 4). The ecological variables Shannon's diversity index $\left(F_{\text {plant }}=0.0017, p_{\text {plant }}=0.9687 ; F_{\text {thin }}=8.2442, p_{\text {thin }}=\right.$ $0.0284)$, and species richness $\left(F_{\text {plant }}=0.0384, \mathrm{p}_{\text {plant }}=0.8511 ; \mathrm{F}_{\text {thin }}=5.5922, \mathrm{p}_{\text {thin }}=0.0559\right)$ differed among thinning treatments, but not plantation arrangement; the thinned stands had about $45 \%$ more species than the unthinned stands (Fig. 9, Table 4). Plantation arrangement or presence of thinning did not affect trees per hectare before thinning, regeneration density per hectare, percent of plot covered by shrubs, and shrub height ( $\mathrm{p}>0.1$, Table 4$)$. The variables basal area per hectare and trees per hectare after thinning did not meet the normality assumption of the model despite multiple transformations; therefore, these models were not used. There were no significant interaction terms among any of the two way ANOVA tests.

\subsubsection{Just Thinned Plantation ANOVA}

I found a similar diameter growth pattern between the plantation arrangements when looking at only thinned plantations. The thinning index for BAI had a trend of the evenly spaced plantations responding $15 \%$ more to thinning than the clustered plantations $(F=6.6395, p=0.061$; Fig. 10, Table 5). None of the other variables tested among only the thinned plantations (BAI and annual height growth after thinning and height growth thinning index) differed among planting arrangement (all $\mathrm{p}>0.1$; Table $5)$.

\subsubsection{Regression Models}

The variables describing growth for all five treatments included density characteristics. BAI before thinning was best described by species richness (negative), frequency of yellow pine (positive), 
and treatment (adjusted $\mathrm{R}^{2}=0.5994$ ). BAI after thinning was best described by the same variables, excluding species richness. $\left(\mathrm{R}^{2}=0.7126\right)$. Annual height growth before thinning was best modeled with the topographic variables of elevation (negative) and aspect (positive), along density of regeneration (negative) and frequency of yellow pine (positive), and treatment (adjusted $\mathrm{R}^{2}=0.7281$ ). Similar to BAI growth, annual height growth after thinning had a simpler model than before thinning. It was best described by trees per hectare after thinning (positive), frequency of yellow pine (positive), and treatment and had an adjusted $\mathrm{R}^{2}$ of 0.5514 (Table 6).

Similar patterns were found in the regression models describing growth for just the plantations (Table 7.). BAI before thinning was best described by shrub cover (negative), species richness (negative), trees per hectare (negative), frequency of yellow pine (positive), planting arrangement, and thinning (adjusted $\mathrm{R}^{2}=0.5859$ ). BAI after thinning was best described with similar, but fewer variables: Shannon's diversity index (negative), frequency of yellow pine (positive), and thinning (adjusted $\mathrm{R}^{2}=$ 0.6237). The variables that best described annual height growth among the plantations stayed the same from before to after thinning: elevation (negative), frequency of yellow pine (positive), and planting arrangement (adjusted $\mathrm{R}^{2}=0.7114,0.5037$ respectively).

\subsection{Discussion}

In the water limiting climate of the Sierra Nevada Mountains, one might expect trees spaced further apart from each other, i.e. evenly spaced plantations in this study, to grow faster more; however my results suggest otherwise. The trees in the clustered plantations put on more diameter growth than the trees in the evenly spaced plantations before thinning (Fig. 8). Further, the trees in the evenly spaced plantations experienced a stronger growth response to thinning than the clustered trees, suggesting that the evenly spaced trees were more suppressed before thinning (Fig. 10). The regression analysis also suggested that the clustered plantations had larger height and diameter growth (Table 7). In the regression tests with just the plantations, plantation arrangement was a significant variable for three out of four tests, all with a negative coefficient for the evenly spaced planting arrangement (arrangement "B"). The results 
suggest that the density of clustering used in the plantations provided a facilitative effect among trees that outweighed the inter-tree competition effect. Similar results of facilitation have been found in young stands of naturally regenerating trees, including a study by Owen et al. (2017) which was conducted on ponderosa pine regeneration after a high severity fire in the western United States (Fajardo and McIntire, 2011; Owen et al., 2017).

It has been shown that trees under water stress will allocate more growth to their roots so they can find new water sources (Kozlowski and Pallardy, 2002). Therefore, in clustered plantations, trees might be initially stressed but this stress is alleviated as their roots extend in search of water to adjacent canopy gaps. These large gaps could provide enough resources for the trees to focus their growth on above ground tissues. Having trees in clusters could also improve their connectivity to mycorrhizal networks. In very dry forests, the facilitative effects of mycorrhizal networks are at their strongest at short distances, and decreases as distance increases (Simard, 2009). This strong network could help a young tree access water. It has been shown that the ectomycorrhizal network of young ponderosa pine trees can access hydraulically redistributed water (Warren et al., 2008). The results suggest that the trees in clusters are possibly more connected into the mycorrhizal network, giving them more access to shared resources, like hydraulically redistributed water.

Frequency of yellow pine was significant in all regression models (Tables $6 \& 7$ ). There are two possible explanations for this trend. Yellow pines could have faster diameter and height growth when accompanied by other yellow pines. Owen et al. (2017) found that in patches of ponderosa pine regeneration after a fire, sapling height was positively correlated with neighboring sapling density, suggesting that young ponderosa pines experience intraspecific facilitation. This study found other evidence of facilitation with the clustered plantations having more diameter growth than the evenly spaced plantations before thinning (Fig. 8), although those were not species specific. However, most of the trees found in the plantations were yellow pines, so it is possible that the results from BAI are reflecting an intraspecific facilitation effect as well. Alternatively, the correlation of yellow pine density with positive diameter and height growth could also be a reflection of site quality. A higher quality site 
can support a greater density of yellow pines and trees would likely exhibit high survival following establishment which ultimately translates to better growth.

Another factor contributing for increased growing was thinning. While BAI in clustered plantations responded to pre-commercial thinning less than the trees in evenly spaced plantations, both did respond positively (Fig. 10). This is a well-documented result, as pre-commercial thinning is a common technique for reducing competition for water and light while increasing growth in young ponderosa pine and mixed conifer stands (Ferguson et al., 2011; Vernon et al., 2018; Zhang et al., 2013b). Pre-commercial thinning has been shown to increase resource availability, including soil moisture, which is incredibly important for ponderosa pine growth, as it is found in dry climates (Chase et al., 2016). Similar responses have been shown in larger trees as well. When used along with prescribed burning, a common restoration technique for ponderosa pine, thinning increased leaf water potential, which means the trees were less water stressed, and increased net photosynthesis, which indicates the trees were able to put on more growth (Skov et al., 2004). The decrease in water stress and increase in net photosynthesis could be attributed to more moisture and nutrient availability, due to reduced competition.

Unfortunately thinning and elevation were confounded in this study. The thinned sites elevation ranged from 1340 to 1570 meters and the unthinned sites ranged from 1940 to 2000 meters (Table 1). I did observe a positive growth effect of thinning, based on the response to thinning index (Fig. 10), however the results from the two-way ANOVA cannot be interpreted the same way. I ran multiple twoway ANOVA tests that showed a significant thinning effect. However, a significant thinning effect was found for several variables that only included data from the years before thinning in 2015 (Table 4). Therefore, elevation, rather than thinning might be the reason for this difference. The regression results also point to an effect of elevation on growth. Test comparing height growth before and after thinning on the plantations and height growth before thinning on all five treatments showed a negative association of growth with elevation (Tables 6 \& 7). Climate does change with elevation on the western side of the Sierra Nevada Mountains. Snowfall increases with elevation from 600 to 2,600 meters, with persistent winter snow above 1200 meters (Western Regional Climate Center, 2018). The increased snowpack at 
higher elevations decreases the amount of growing days because the larger snowpack will persist longer into the spring and summer. As with other conifers, photosynthesis and respiration in ponderosa pine decreases greatly over wintertime due to the colder temperatures effects on enzyme activity (Adams et al., 2002; Law et al., 1999). Therefore, the decrease in growing days could explain why I found slower growth in the unthinned, higher elevation plantations.

While I cannot determine the specific mechanism influencing the patterns of species diversity found, past studies suggest that the patterns could result from an interaction of thinning and elevation. There was higher species diversity and richness in the thinned, lower elevation sites (Fig. 9). Multiple studies in the Sierra Nevada have shown that species richness decreases as elevation increases (Klinger et al., 2006; Rundel and Keeley, 2016; Wathen et al., 2014). This decrease in richness is often attributed to a decrease in invasive plants with higher elevations (Klinger et al., 2006; Rundel and Keeley, 2016). Similarly to the growth patterns with elevation, this relationship could also result from the shorter growing season and cooler temperatures at high elevations (Rundel and Keeley, 2016; Western Regional Climate Center, 2018). It has also been shown that species richness, especially non-native species richness, increases with thinning and fuel treatments in Sierra Nevada forests. Several studies have found increased native and non-native species richness with shrub removal in post-fire plantations in the Sierra Nevada (Bohlman et al., 2016; McGinnis et al., 2010). The increases in plant richness after shrub removal and thinning is most likely due to an increase in the light environment after treatment, allowing for more species to colonize (Wayman and North, 2007). I did not distinguish between native and non-native species in the surveys, but I did observe high amounts of cheatgrass (Bromus tectorum L.), a common invasive species in the Sierra Nevada, in the thinned, lower elevation stands (Keeley, 2006).

Drought recovery is another potential confounding factor in this study. California experienced one of the worst droughts in its recent history from 2012-2015 (Luo et al., 2017). However, an extreme El Niño event in the winter of 2015/16 left the state with a large snowpack, ameliorating some of the impacts of the drought (Wahl et al., 2017). The drought recovery period coincided with the thinning of the sampled plantations; 2016 was the first growing season after thinning and the end of the drought. While I 
do believe that some of the increased growth after thinning was influenced by the release, it can also be attributed, in part to the drought ending. The dramatic increase in winter snowpack most likely had a beneficial influence on the change in growth as soil moisture is one of the most important factors for young trees' growth in the mixed conifer forests of the Sierra Nevada (Gray et al., 2005).

In addition to the effects of plantation arrangement and thinning, I observed differences among the plantations and naturally regenerating stands. There were consistent growth patterns among the five treatment groups. Natural regenerating stands grew slower than the thinned plantations; however they did not differ from the unthinned plantations (Figs. $4 \& 5$ ). Similarly to the lower growth in the unthinned plantations due to increased elevation, an environmental factor could explain the reduced growth in the naturally regenerating stands. For a stand to naturally regenerate, there needs to be a nearby seed source of overstory trees, which can shade the newly established seedlings. The Forest Service established the plantations in this study in areas where a majority of the overstory trees died in the fire, resulting in less shade on the young trees when compared to the naturally regenerating stands. This difference in light environment could influence the growth differences seen, as light is an important factor in young tree growth in these forests (Gray et al., 2005; McDonald, 1976).

There was extreme variation in tree stocking within treatments and stands. (Fig. 6). One would expect to see a difference between the thinned and unthinned stands, since they were planted at the same density, but then half of them were thinned. One explanation might be the extreme variation in tree survival within stands, especially the higher elevation, unthinned stands. The standard deviation of trees per hectare for the unthinned plots was three times larger than the standard deviation for the thinned plots (Table 8). While I only sampled stands that had overall successful conifer establishment, several stands were spatially heterogeneous with their success; some plots had many trees while others had few. The range in tree density observed in unthinned stands might be explained by shrub competition limited successful tree establishment (McDonald and Fiddler, 2010; Zhang et al., 2006) and proximity to seed sources, with plots near existing overstory trees exhibiting the greatest increase from the original planting density. The standard deviation for trees per hectare among natural regenerating plots was about five 
times higher than for the standard deviation for the thinned plots. However, this extreme variation in the natural regenerating stands is expected. Multiple studies have found that mixed conifer establishment after a high severity fire is often patchy and variable (Collins and Roller, 2013; North et al., 2019; Welch et al., 2016).

Shrubs establishment after fire is inevitable in the Sierra Nevada but often has a negative impact on growth for young trees. With successful conifer establishment, natural regenerating stands had a trend of shorter mean shrub height than the plantations (Fig. 7). This could also be attributed to differences in the light environments between plantations and naturally regenerating stands. The canopy cover needed for seedling establishment could result in less light, thus suppressing the growth of shrubs in the stand. Unmanaged stands after a high severity fire are often dominated by large shrubs, as they have a persistent seedbank and grow faster than conifer seedlings (Collins and Roller, 2013; Nagel and Taylor, 2005; Zald et al., 2008). I also found shrub area to have a negative effect on BAI before thinning among the plantations (Table 5). Shrubs are fierce competitors for light and soil moisture, two resources that are integral for growth in recently established seedlings (McDonald and Fiddler, 2010; North et al., 2019; Zhang et al., 2006). In fact, many of the original established plantations did not survive due to shrub encroachment (U.S. Department of Agriculture (USDA) Forest Service, 2017).

\subsection{Conclusion}

This research helps illuminate the facilitative effects that young trees can have on each other, as well as the effects of different stressors in post fire plantations in the Sierra Nevada Mountains. I found a positive diameter growth effect in trees growing in clusters when compared to evenly spaced trees. The clusters could be arranged in a way that encourages roots growth and or ectomycorrhizal network development, potentially giving the young trees more access to resources like water and nutrients. This is one of the first studies performed on clustered plantations in the Sierra Nevada, so there is still much to investigate on their advantages and disadvantages. I also found effects of thinning, shrubs competition, and elevation on growth and species diversity, which are likely a response to different light and moisture environments. The patterns of facilitation (improved growth in clusters) and competition (positive growth 
response to thinning) highlight the importance of spatial scales when looking into growth relationships. I observed facilitation when looking into the small spatial scale of BAI within a cluster, while I observed a beneficial release from competition, at the plantation scale. I suggest conducting future research into the effects of spatial aggregation and density on tree growth to better understand this relationship. Comparing growth among different densities of tree clusters could provide insight on at what scales neighboring trees compete or facilitate. Continuing research into how these different planting arrangements respond to different climate stressors, like drought, and how their growth changes over an elevational gradient will help clarify the confounding factors in the study. As the forest service's ability to intensively manage young stands decreases due to funding and increasing fires, identifying the post fire management options that require the least amount of maintenance to become healthy and fire-resilient is becoming more important. 


\subsection{Works Cited}

Adams, W. W. I., Demming-Adams, B., Rosentiel, T. N., Brightwell, A. K., \& Ebbert, V. (2002). Photosynthesis and photoprotection in Overwinter Plants. Plant Biology, 4(5), 545-557. https://doi.org/10.1055/s-2002-35434

Agee, J. K. (1993). Fire Ecology of Pacific Northwest Forests. Washington, D.C.: Island Publisher.

Bailey, R. (2016). Bailey's ecoregions and subregions of the United States, Puerto Rico, and the U.S. Virgin Islands. Ft. Collins, CO: Forest Service Research Data Archive. https://doi.org/10.2737/RDS-2016-0003

Bohlman, G. N., North, M. P., \& Safford, H. D. (2016). Shrub removal in reforested post-fire areas increases native plant species richness. Forest Ecology and Management, 374, 195-210. https://doi.org/10.1016/j.foreco.2016.05.008

Bonnet, V. H., Schoettle, a W., \& Shepperd, W. D. (2005). Postfire environmental conditions influence the spatial pattern of regeneration for Pinus ponderosa. Canadian Journal of Forest Research, 35, 37-47. https://doi.org/10.1139/X04-157

Bunn, A. G. (2008). A dendrochronology program library in R (dplR). Dendrochronologia, 26(2), 115124. https://doi.org/10.1016/j.dendro.2008.01.002

Chase, C. W., Kimsey, M. J., Shaw, T. M., \& Coleman, M. D. (2016). The response of light, water, and nutrient availability to pre-commercial thinning in dry inland Douglas-fir forests. Forest Ecology and Management, 363, 98-109. https://doi.org/10.1016/j.foreco.2015.12.014

Churchill, D. J., Larson, A. J., Dahlgreen, M. C., Franklin, J. F., Hessburg, P. F., \& Lutz, J. A. (2013). Restoring forest resilience: From reference spatial patterns to silvicultural prescriptions and monitoring. Forest Ecology and Management, 291, 442-457. https://doi.org/10.1016/j.foreco.2012.11.007

Collins, B. M., \& Roller, G. B. (2013). Early forest dynamics in stand-replacing fire patches in the northern Sierra Nevada, California, USA. Landscape Ecology, 28(9), 1801-1813. https://doi.org/10.1007/s10980-013-9923-8

Cybis Electronic. (2018). CDendro and CooRecorder.

Duchesneau, R., Lesage, I., Messier, C., \& Morin, H. (2001). Effects of light and intraspecific competition on growth and crown morphology of two size classes of understory balsam fir saplings. Forest Ecology and Management, 140(2-3), 215-225. https://doi.org/10.1016/S03781127(00)00281-4

Eldorado National Forest. (2014). Power Fire Reforestation Project.

Fajardo, A., \& McIntire, E. J. B. (2011). Under strong niche overlap conspecifics do not compete but help each other to survive: Facilitation at the intraspecific level. Journal of Ecology, 99(2), 642-650. https://doi.org/10.1111/j.1365-2745.2010.01771.x

Ferguson, D. E., Byrne, J. C., Wykoff, W. R., Kummet, B., \& Hensold, T. (2011). Response of ponderosa pine stands to pre-commercial thinning: On Nez Perce and spokane tribal forests in the Inland Northwest, USA. USDA Forest Service - Research Paper RMRS-RP, (88 RP), 1-33. Retrieved from http://www.scopus.com/inward/record.url?eid=2-s2.080052320905\&partnerID $=40 \& \mathrm{md} 5=7 \mathrm{f} 23 \mathrm{cccd} 91477 \mathrm{bc} 7 \mathrm{bd} 1 \mathrm{~d} 18 \mathrm{e} 7 \mathrm{dfa} 070 \mathrm{df}$

Fites-Kaufman, J. A., Rundel, P., Stephenson, N., \& Weixelman, D. A. (2007). Montane and Subalpine Vegetation of the Sierra Nevada and Cascade Ranges. In Terrestrial Vegetation of California, 3rd Edition (pp. 456-501). https://doi.org/10.1525/california/9780520249554.003.0017

Gray, A. N., Zald, H. S. J., Kern, R. A., \& North, M. P. (2005). Stand conditions associated with tree regeneration in Sierran mixed-conifer forests. Forest Science, 51(3), 198-210.

Hann, W. J., Shlisky, A., Havlina, D., Schon, K., Barrett, S. W., DeMeo, T. E., ... Frame, C. K. (2008). Interagency Fire Regime Condition Class Guidebook (FRCC) guidebook. Homepage of the Interagency and The Nature Conservancy Fire Regime Condition Class website, USDA Forest Service, U.S. Department of the Interior, The Nature Conservancy, and Systems for Environmental Management. Retrieved from www.frcc.gov 
Holmgren, M. (2000). Combined Effects of Shade and Drought on Tulip Poplar Seedlings : Trade-Off in Tolerance or Facilitation? Nordic Society Oikos, 90(1), 67-78.

Keeley, J. E. (2006). Fire management impacts on invasive plants in the western United States. Conservation Biology, 20(2), 375-384. https://doi.org/10.1111/j.1523-1739.2006.00339.x

Klinger, R., Underwood, E. C., \& Moore, P. E. (2006). The role of environmental gradients in non-native plant invasion into burnt areas of Yosemite National Park, California. Diversity and Distributions, 12(2), 139-156. https://doi.org/10.1111/j.1366-9516.2005.00203.x

Kobziar, L. N., Mcbride, J. R., \& Stephens, S. L. (2009). The efficacy of fire and fuels reduction treatments in a Sierra Nevada pine plantation. International Journal of Wildland Fire, 791-801.

Kozlowski, T. ., \& Pallardy, S. G. (2002). Acclimation and Adaptive Responses of Woody Plants to Environmental Stresses. The Botanical Review, 68(2), 270-334.

Law, B. E., Ryan, M. G., \& Anthoni, P. M. (1999). Seasonal and annual respiration of a ponderosa pine ecosystem. Global Change Biology, 5(2), 169-182. https://doi.org/10.1046/j.13652486.1999.00214.x

Luo, L., Apps, D., Arcand, S., Xu, H., Pan, M., \& Hoerling, M. (2017). Contribution of temperature and precipitation anomalies to the California drought during 2012-2015. Geophysical Research Letters, 44(7), 3184-3192. https://doi.org/10.1002/2016GL072027

McDonald, P. M. (1976). Forest regeneration and seedling growth from five major cutting methods in north-central California, (Research Paper PSW-115), 10.

McDonald, P. M., \& Fiddler, G. O. (2010). Twenty-five years of managing vegetation in conifer plantations in northern and central California: results, application, principles, and challenges. Gen. Tech. Rep. PSW-GTR_231. Albany, CA: USDA Forest Service. Retrieved from http://www.srs.fs.usda.gov/pubs/37965

McGinnis, T. W., Keeley, J. E., Stephens, S. L., \& Roller, G. B. (2010). Fuel buildup and potential fire behavior after stand-replacing fires, logging fire-killed trees and herbicide shrub removal in Sierra Nevada forests. Forest Ecology and Management, 260(1), 22-35. https://doi.org/10.1016/j.foreco.2010.03.026

Miller, J. D., \& Safford, H. D. (2012). Trends in wildfire severity: 1984 to 2010 in the Sierra Nevada, Modoc Plateau, and southern Cascades, California, USA. Fire Ecology, 8(3), 41-57. https://doi.org/10.4996/fireecology.0803041

Nagel, T. A., \& Taylor, A. H. (2005). Fire and persistence of montane chaparral in mixed conifer forest landscapes in the northern Sierra Nevada, Lake Tahoe Basin, California, USA. Journal of the Torrey Botanical Society, 132(3), 442-457.

Natural Resource Conservation Service. (2018). Web Soil Survey.

North, M. P., Stevens, J. T., Greene, D. F., Coppoletta, M., Knapp, E. E., Latimer, A. M., ... Wyrsch, P. (2019). Tamm Review: Reforestation for resilience in dry western U.S. forests. Forest Ecology and Management, 432(July 2018), 209-224. https://doi.org/10.1016/j.foreco.2018.09.007

North, M. P., Stine, P. A., O’Hara, K., Zielinski, W. J., Stephens, S. L., Service, F., \& Hara, K. O. (2009). An ecosystem management strategy for Sierran mixed- conifer forests. Gen. Tech. Rep. PSWGTR-220. Albany, CA, USA: USDA Forest Service.

Owen, S. M., Sieg, C. H., Sánchez Meador, A. J., Fulé, P. Z., Iniguez, J. M., Baggett, L. S., ... Battaglia, M. A. (2017). Spatial patterns of ponderosa pine regeneration in high-severity burn patches. Forest Ecology and Management, 405(July), 134-149. https://doi.org/10.1016/j.foreco.2017.09.005

Royce, E. B., \& Barbour, M. G. (2001). Mediterranean climate effects. I. Conifer water use across a Sierra Nevada ecotone. American Journal of Botany, 88(5), 911-918.

RStudio Team. (2018). RStudio: Integrated Development for R. Boston, MA. Retrieved from http://www.rstudio.com/

Rundel, P. W., \& Keeley, J. E. (2016). Dispersal Limitation Does Not Control High Elevational Distribution of Alien Plant Species in the Southern Sierra Nevada, California. Natural Areas Journal, 36(3), 277-287. https://doi.org/10.3375/043.036.0308 
Russell, W. H., Mcbride, J. R., \& Rowntree, R. (1998). Revegtation after four stand replacing fires in the Lake Tahoe Basin. Madrono, 45(1), 40-46.

SAS Institute Inc. (2018). JMP.

Simard, S. W. (2009). The foundational role of mycorrhizal networks in self-organization of interior Douglas-fir forests. Forest Ecology and Management, 258(SUPPL.), 95-107. https://doi.org/10.1016/j.foreco.2009.05.001

Skov, K. R., Kolb, T. E., \& Wallin, K. F. (2004). Tree Size and Drought Affect Ponderosa Pine Physiological Response to Thinning and Burning Treatments. Forest Science, 50(1), 1-11.

Tappeiner, J. C., \& McDonald, P. M. (1996). Regeneration of Sierra Nevada forests. Sierra Nevada Ecosystem Project Final Report to Congress: Status of the Sierra Nevada, 3, 501-513.

U.S. Department of Agriculture (USDA) Forest Service. (2017). Final Environmental Impact Statement Power Fire Reforestation Project.

USDA Forest Service. (2004). Record of Decision. Sierra Nevada Forest Plan Amendment - Final Supplemental Environmental Impact Statement, 72. Retrieved from http://www.fs.usda.gov/detail/r5/landmanagement/planning/?cid=STELPRDB5349922

Vernon, M. J., Sherriff, R. L., van Mantgem, P., \& Kane, J. M. (2018). Thinning, tree-growth, and resistance to multi-year drought in a mixed-conifer forest of northern California. Forest Ecology and Management, 422(April), 190-198. https://doi.org/10.1016/j.foreco.2018.03.043

Wahl, E. R., Diaz, H. F., Vose, R. S., \& Gross, W. S. (2017). Multicentury evaluation of recovery from strong precipitation deficits in California. Journal of Climate, 30(15), 6053-6063. https://doi.org/10.1175/JCLI-D-16-0423.1

Warren, J. M., Brooks, J. R., Meinzer, F. C., \& Eberhart, J. L. (2008). Hydraulic redistribution of water from Pinus ponderosa trees to seedlings: Evidence for an ectomycorrhizal pathway. New Phytologist, 178(2), 382-394. https://doi.org/10.1111/j.1469-8137.2008.02377.x

Wathen, S., Thorne, J. H., Holguin, A., \& Schwartz, M. W. (2014). Estimating the spatial and temporal distribution of species richness within Sequoia and Kings Canyon National Parks. PLoS ONE, 9(12), 1-25. https://doi.org/10.1371/journal.pone.0112465

Wayman, R. B., \& North, M. P. (2007). Initial response of a mixed-conifer understory plant community to burning and thinning restoration treatments. Forest Ecology and Management, 239(1-3), 3244. https://doi.org/10.1016/j.foreco.2006.11.011

Welch, K. R., Safford, H. D., \& Young., T. P. (2016). Predicting conifer establishment 5-7 years after wildfire in middle elevation yellow pine and mixed conifer forests of the North American Mediterranean-climate zone. Ecosphere, in press(December). https://doi.org/10.1002/ecs2.1609

Westerling, A. L., \& Bryant, B. P. (2007). Climate change and wildfire in California. Climatic Change, 87(1 SUPPL). https://doi.org/10.1007/s10584-007-9363-z

Western Regional Climate Center. (2018). CLIMATE OF CALIFORNIA. Retrieved from https://wrcc.dri.edu/narratives/CALIFORNIA.htm

Zald, H. S. J., Gray, A. N., North, M. P., \& Kern, R. A. (2008). Initial tree regeneration responses to fire and thinning treatments in a Sierra Nevada mixed-conifer forest, USA. Forest Ecology and Management, 256(1-2), 168-179. https://doi.org/10.1016/j.foreco.2008.04.022

Zhang, J., Oliver, W. W., \& Busse, M. D. (2006). Growth and development of ponderosa pine on sites of contrasting productivities : relative importance of stand density and shrub competition effects 1 . Canadian Journal of Forest Research, 2438, 2426-2438. https://doi.org/10.1139/X06-078

Zhang, J., Ritchie, M. W., Maguire, D. A., \& Oliver, W. W. (2013). Thinning ponderosa pine ( Pinus ponderosa ) stands reduces mortality while maintaining stand productivity. Canadian Journal of Forest Research, 43(4), 311-320. https://doi.org/10.1139/cjfr-2012-0411 


\subsection{Figures and Tables}

Table 1. Characteristics of sampled stands. Slope, elevation, and aspect are averaged across the plots per stand

\begin{tabular}{lllllll}
\hline StandID & Plantation Arrangement & Thinned & \# of plots & $\begin{array}{l}\text { Slope } \\
\text { (degrees) }\end{array}$ & $\begin{array}{l}\text { Elevation } \\
(\mathrm{m})\end{array}$ & Aspect \\
\hline A102 & Clustered (A) & Yes & 5 & 19.4 & 1416.6 & 255.6 \\
A137 & Clustered (A) & Yes & 5 & 26.6 & 1427.4 & 121.0 \\
A78 & Clustered (A) & Yes & 5 & 12.4 & 1555.0 & 90.2 \\
B139 & Evenly Spaced (B) & Yes & 5 & 29.2 & 1358.4 & 106.0 \\
B140 & Evenly Spaced (B) & Yes & 5 & 28.6 & 1355.9 & 157.0 \\
B82 & Evenly Spaced (B) & Yes & 5 & 15.0 & 1434.8 & 134.6 \\
A217 & Clustered (A) & No & 5 & 13.2 & 1961.4 & 122.2 \\
A25 & Clustered (A) & No & 5 & 9.4 & 1984.8 & 200.2 \\
B13 & Evenly Spaced (B) & No & 5 & 10.4 & 1970.9 & 126.4 \\
B24 & Evenly Spaced (B) & No & 5 & 10.0 & 1939.6 & 182.4 \\
NRG147 & Natural Regeneration (NRG) & NA & 7 & 14.7 & 1460.6 & 114.6 \\
NRG164 & Natural Regeneration (NRG) & NA & 8 & 6.9 & 1525.3 & 71.9 \\
NRG17 & Natural Regeneration (NRG) & NA & 5 & 15.6 & 2011.4 & 121.6 \\
NRG302 & Natural Regeneration (NRG) & NA & 5 & 15 & 1794.9 & 200.4 \\
\hline
\end{tabular}

Table 2. Species composition of the sampled stands in trees per hectare. $\mathrm{ABCO}=$ Abies concolor, $\mathrm{ABMA}$ $=$ Abies magnifica, $\mathrm{CADE}=$ Calocedrus decurrens, $\mathrm{PIJE}=$ Pinus jeffreyi, $\mathrm{PIPO}=$ Pinus ponderosa, $\mathrm{PILA}$ = Pinus lambertiana , PSME = Pseudotusga menziesii .

\begin{tabular}{|c|c|c|c|c|c|c|c|c|c|c|c|}
\hline StandID & Plant & Thinned & $\mathrm{ABCO}$ & ABMA & CADE & PIJE & PIPO & PILA & PSME & Hardwoods & Total \\
\hline A217 & Clustered (A) & No & 10 & 120 & 0 & 1120 & 0 & 50 & 0 & 170 & 1470 \\
\hline A25 & Clustered (A) & No & 20 & 0 & 50 & 480 & 0 & 0 & 0 & 0 & 550 \\
\hline A102 & Clustered (A) & Yes & 0 & 0 & 60 & 0 & 220 & 0 & 0 & 70 & 350 \\
\hline A137 & Clustered (A) & Yes & 0 & 0 & 10 & 0 & 290 & 10 & 0 & 390 & 700 \\
\hline A78 & Clustered (A) & Yes & 0 & 0 & 20 & 0 & 260 & 0 & 0 & 0 & 280 \\
\hline B13 & Evenly Spaced (B) & No & 0 & 30 & 60 & 1450 & 0 & 0 & 0 & 0 & 1540 \\
\hline B24 & Evenly Spaced (B) & No & 0 & 70 & 0 & 110 & 10 & 10 & 0 & 0 & 200 \\
\hline B139 & Evenly Spaced (B) & Yes & 0 & 0 & 60 & 0 & 360 & 0 & 70 & 190 & 680 \\
\hline B140 & Evenly Spaced (B) & Yes & 0 & 0 & 30 & 0 & 370 & 0 & 0 & 40 & 440 \\
\hline B82 & Evenly Spaced (B) & Yes & 0 & 0 & 40 & 0 & 290 & 0 & 0 & 50 & 380 \\
\hline NRG147 & $\begin{array}{l}\text { Natural } \\
\text { Regeneration (NRG) }\end{array}$ & NA & 7 & 0 & 821 & 0 & 1550 & 14 & 0 & 7 & 2399 \\
\hline NRG164 & $\begin{array}{l}\text { Natural } \\
\text { Regeneration (NRG) }\end{array}$ & NA & 56 & 0 & 519 & 0 & 1344 & 56 & 13 & 13 & 2001 \\
\hline NRG17 & $\begin{array}{l}\text { Natural } \\
\text { Regeneration (NRG) }\end{array}$ & NA & 10 & 10 & 10 & 30 & 60 & 0 & 0 & 0 & 120 \\
\hline NRG302 & $\begin{array}{l}\text { Natural } \\
\text { Regeneration (NRG) }\end{array}$ & NA & 0 & 0 & 30 & 20 & 250 & 10 & 0 & 240 & 550 \\
\hline
\end{tabular}


Table 3. Results from one way ANOVA among the five overall treatment categories (TRT). * indicates significance at 0.1 level, ** indicates significance at 0.05 level for TRT. Regen/ Hec $=$ trees below $1.37 \mathrm{~m}$ per hectare; $\mathrm{TPH}=$ trees per hectare; $\mathrm{BAI}=$ basal area increment

\begin{tabular}{|c|c|c|c|c|c|c|c|c|}
\hline Variable & Type & $\begin{array}{l}\text { Trans- } \\
\text { formation }\end{array}$ & $\mathrm{F}_{\mathrm{TRT}}$ & $\mathrm{p}_{\text {TRT }}$ & $\mathrm{F}_{\text {stand }}$ & $p_{\text {stand }}$ & $\mathrm{F}_{\text {plot }}$ & pplot \\
\hline Regen/ Hec & Density & $(\ln (y+1))^{\wedge} 2$ & 2.5624 & 0.1099 & 3.0962 & 0.004 & NA & NA \\
\hline TPH before thinning & Density & NA & 0.5818 & 0.6835 & 3.4799 & 0.0016 & NA & NA \\
\hline TPH after thinning & Density & $(\ln (y+1))^{\wedge} 2$ & 0.0987 & 0.9803 & 4.8645 & $<0.0001$ & NA & NA \\
\hline Shrub \% & Ecology & NA & 1.4448 & 0.2928 & 1.6026 & 0.1347 & NA & NA \\
\hline Shrub height & Ecology & $\ln (y+1)$ & 3.5124 & $0.0517 *$ & 4.0311 & 0.0003 & 2.4267 & $<0.0001$ \\
\hline $\begin{array}{l}\text { Shannon's diversity } \\
\text { index }\end{array}$ & Ecology & NA & 1.8777 & 0.1961 & 2.4770 & 0.0176 & NA & NA \\
\hline Species richness & Ecology & NA & 2.3552 & 0.1285 & 2.0857 & 0.0446 & NA & NA \\
\hline Total height & Growth & NA & 35.2145 & $<0.0001 * *$ & 0.7037 & 0.7030 & 3.1674 & $<0.0001$ \\
\hline DBH & Growth & NA & 25.7876 & $<0.0001 * *$ & 1.5561 & 0.1428 & 7.8319 & $<0.0001$ \\
\hline BAI before thinning & Increment & $\ln (y+1)$ & 8.5649 & $0.0018 * *$ & 0.6978 & 0.6916 & 2.1503 & 0.0008 \\
\hline $\begin{array}{l}\text { Annual height } \\
\text { growth before } \\
\text { thinning }\end{array}$ & Increment & NA & 37.5876 & $<0.0001 * *$ & 0.7165 & 0.6917 & 3.4618 & $<0.0001$ \\
\hline
\end{tabular}




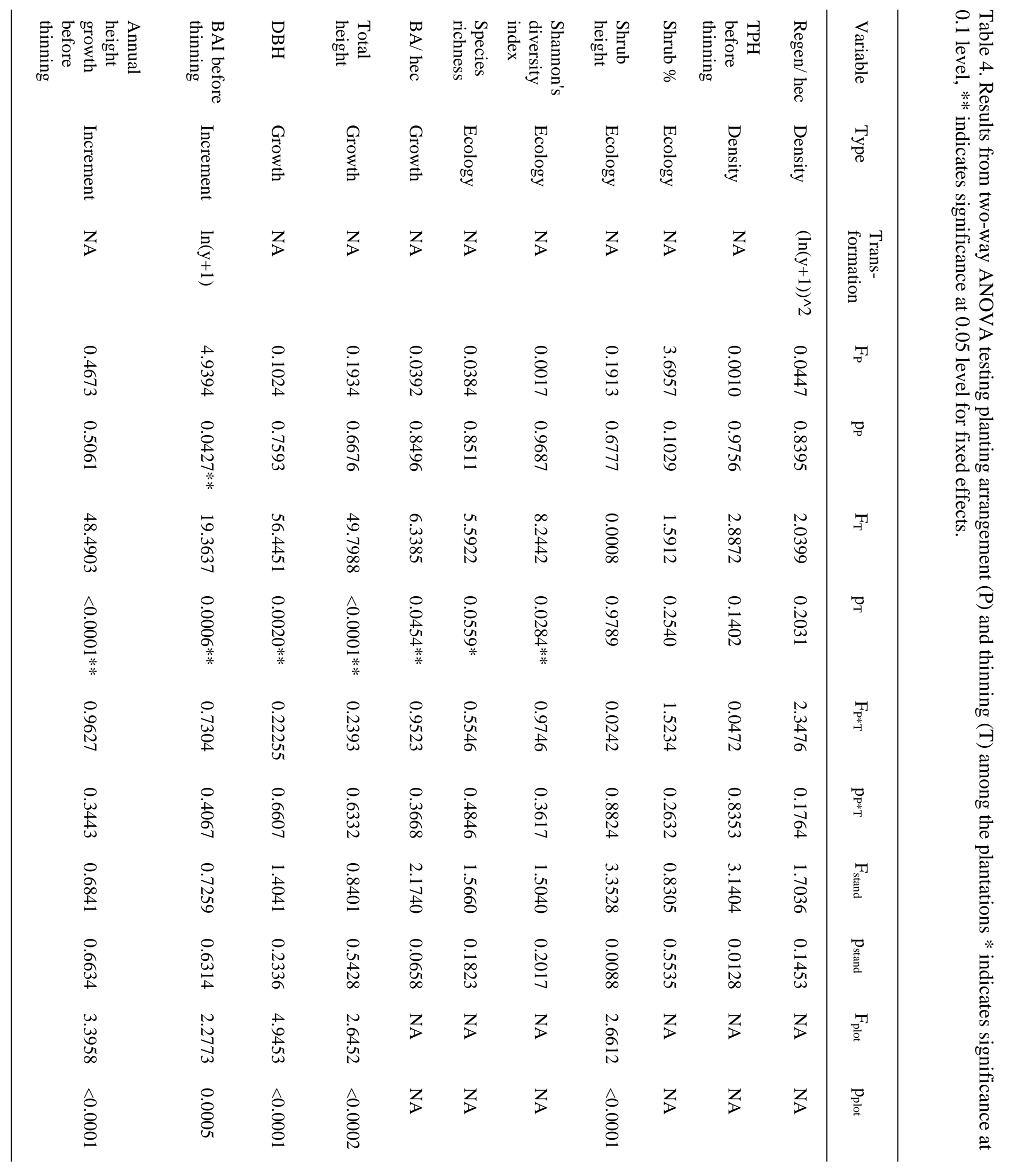


Table 5. Results from one way ANOVA on just thinned plantations comparing planting arrangements. * indicates significance at 0.1 level, for fixed effects

\begin{tabular}{lllllllll} 
Variable & Type & Transformation & $\mathrm{F}_{\text {plant }}$ & $\mathrm{p}_{\text {plant }}$ & $\mathrm{F}_{\text {stand }}$ & $\mathrm{p}_{\text {stand }}$ & $\mathrm{F}_{\text {plot }}$ & $\mathrm{p}_{\text {plot }}$ \\
\hline BAI 2016 & Increment & $\mathrm{NA}$ & 0.0220 & 0.8892 & 1.0025 & 0.4251 & 2.3443 & 0.0020 \\
$\begin{array}{l}\text { BAI thinning index } \\
\begin{array}{l}\text { Annual height } \\
\text { growth after 2016 }\end{array}\end{array}$ & Index & $(\mathrm{y}+1)^{\wedge} 1 / 6$ & 6.6395 & $0.0610^{*}$ & 0.4005 & 0.8063 & 3.9943 & 0.00001 \\
$\begin{array}{l}\text { Annual height } \\
\text { index }\end{array}$ & Increment & $\mathrm{NA}$ & 0.5945 & 0.4833 & 1.3160 & 0.2912 & 1.6398 & 0.0473 \\
\hline
\end{tabular}

Table 6. Final selection for linear regression models predicting growth in mixed conifer plantations and natural regenerating stands. $\mathrm{Rich}=$ species richness, freq $\mathrm{YP}=$ the frequency of yellow pines, regencount $=$ density of regeneration (trees under $1.37 \mathrm{~m}$ ), TPH $=$ trees per hectare, TrtAY $=$ dummy variable for clustered, thinned plantations, TrtBN = dummy variable for evenly spaced, unthinned plantations, TrtBY = dummy variable for evenly spaced, thinned plantations, TrtNRG = dummy variable for natural regenerating stands.

\begin{tabular}{|c|c|c|}
\hline $\begin{array}{l}\text { Dependent } \\
\text { Variable }\end{array}$ & Explanatory variable with coefficients & $\operatorname{Adj} R^{2}$ \\
\hline $\begin{array}{l}\text { BAI before } \\
\text { thinning }\end{array}$ & $\begin{array}{l}(-82.72 * \text { rich })+(575.71 * \text { freqYP })+(1155.19 * \operatorname{TrtAY})+(-419.44 * \operatorname{TrtBN})+ \\
(868.42 * \operatorname{TrtBY})+(-809.55 * \operatorname{TrtNRG})\end{array}$ & 0.5594 \\
\hline $\begin{array}{l}\text { BAI after } \\
\text { thinning }\end{array}$ & $\begin{array}{l}(761.6 * \text { freqYP })+(2049 * \operatorname{Trt} \mathrm{AY})+(-557.7 * \operatorname{TrtBN})+(2078.3 * \operatorname{TrtBY})+(- \\
1132 * \operatorname{TrtNRG})\end{array}$ & 0.7126 \\
\hline BAI 2013-2016 & $\begin{array}{l}(482 * \text { freq } Y P)+(1091.9 * \operatorname{Trt} A Y)+(-332.9 * \operatorname{TrtBN})+(934.8 * \operatorname{TrtBY})+(- \\
705.9 * \operatorname{TrtNRG})\end{array}$ & 0.6709 \\
\hline $\begin{array}{l}\text { Height growth } \\
\text { before thinning }\end{array}$ & $\begin{array}{l}(-0.0003 * \text { elevation })+(0.0004 * \text { aspect })+(-0.0003 * \text { regencount }) \\
(0.2068 * \text { freqYP })+(0.1750 * \operatorname{Trt} \mathrm{AY})+(-0.0336 * \mathrm{TrtBN})+(0.0822 * \mathrm{TrtBY}) \\
+(-0.1259 * \mathrm{TrtNRG})\end{array}$ & 0.7281 \\
\hline $\begin{array}{l}\text { Height growth } \\
\text { after thinning }\end{array}$ & $\begin{array}{l}(0.00003 * \mathrm{TPH} \text { before thinning })+(0.1798 * \text { freq YP })+(0.248 * \operatorname{Trt} \mathrm{AY})+(- \\
0.0790 * \operatorname{TrtBN})+(0.1970 * \operatorname{TrtBY})+(-0.1470 * \operatorname{TrtNRG})\end{array}$ & 0.5514 \\
\hline $\begin{array}{l}\text { Height growth } \\
\text { 2013-2016 }\end{array}$ & $\begin{array}{l}(0.0005 * \text { aspect })+(0.00004 * \mathrm{TPH} \text { after thinning })+(0.1822 * \text { freq YP })+ \\
(0.3415 * \operatorname{TrtAY})+(-0.03429 * \operatorname{TrtBN})+(0.2812 * \operatorname{TrtBY})+(- \\
0.0851 * \operatorname{TrtNRG})\end{array}$ & 0.7464 \\
\hline
\end{tabular}


Table 7. Final selection for linear regression models predicting growth in plantations. Shrub cover $=\%$ of plot covered with shrubs, rich $=$ species richness, $\mathrm{TPH}=$ trees per hectare, freqYP $=$ the frequency of yellow pines, $\mathrm{PlantB}=$ dummy variable for clustered plantations, Thin $Y=$ dummy variable for thinned plantations, shan. $\mathrm{H}=$ Shannon's diversity index.

\begin{tabular}{llc}
$\begin{array}{l}\text { Dependent } \\
\text { Variable }\end{array}$ & Explanatory variable with coefficients & Adj R $^{\mathbf{2}}$ \\
\hline $\begin{array}{l}\text { BAI before } \\
\text { thinning }\end{array}$ & $\begin{array}{l}(-1024.6239 * \text { shrub cover })+(-201.2 * \text { rich })+(-0.2345 * \text { TPH before thinning }) \\
+(1283 * \text { freq YP })+(-412.5 * \text { PlantB })+(1463 * \text { ThinY })\end{array}$ & 0.5859 \\
\hline $\begin{array}{l}\text { BAI after } \\
\text { thinning }\end{array}$ & \begin{tabular}{l}
$(-651.6 *$ shan.H $)+(1430.9 *$ freqYP $)+(2531.2 *$ ThinY $)$ \\
\hline BAI 2013-2016
\end{tabular} & $\begin{array}{l}(-116.3 * \text { rich })+(-0.20492 * \text { TPH after thinning })+(1088.742 * \text { freq YP })+ \\
(1478.089 * \text { ThinY })\end{array}$ \\
\hline $\begin{array}{l}\text { Height growth } \\
\text { before thinning }\end{array}$ & $(-0.0006 *$ elevation $)+(0.2606 *$ freqYP $)+(-0.08574 *$ PlantB $)$ & 0.6356 \\
\hline $\begin{array}{l}\text { Height growth } \\
\text { after thinning }\end{array}$ & $(-0.0004 *$ elevation $)+(0.259 *$ freqYP $)+(-0.0842 *$ PlantB $)$ & 0.7114 \\
\hline $\begin{array}{l}\text { Height growth } \\
2013-2016\end{array}$ & $(-0.0006 *$ elevation $)+(0.2602 *$ freqYP $)+(-0.8539 *$ PlantB $)$ & 0.5037 \\
\hline
\end{tabular}

Table 8. Mean and (standard deviation) of trees per hectare before and after thinning

\begin{tabular}{llllll} 
& Clust. No Thin & Clust. Thin & Even No Thin & Even Thin & Nat. Regen. \\
\hline $\begin{array}{l}\text { Pre Thinning } \\
\text { TPH }\end{array}$ & $1000(1284)$ & $1773(924)$ & $870(850)$ & $1870(1412)$ & $1436(1575)$ \\
$\begin{array}{l}\text { Post Thinning } \\
\text { TPH }\end{array}$ & $1000(1284)$ & $450(367)$ & $870(850)$ & $500(270)$ & $1436(1575)$ \\
\hline
\end{tabular}




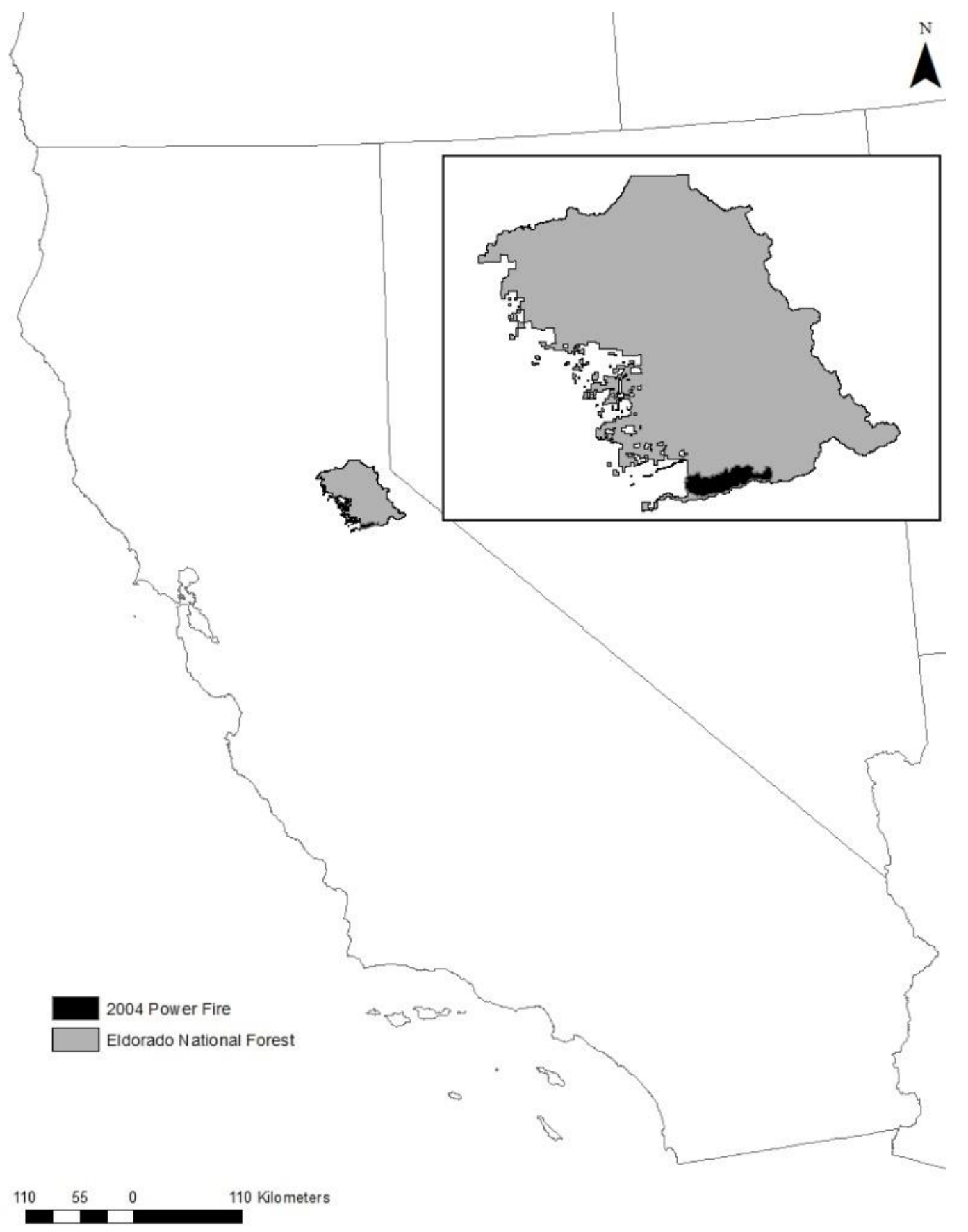

Figure 1. Location of Eldorado National Forest (gray) and the perimeter of the 2004 Power Fire (black) in Northern California 


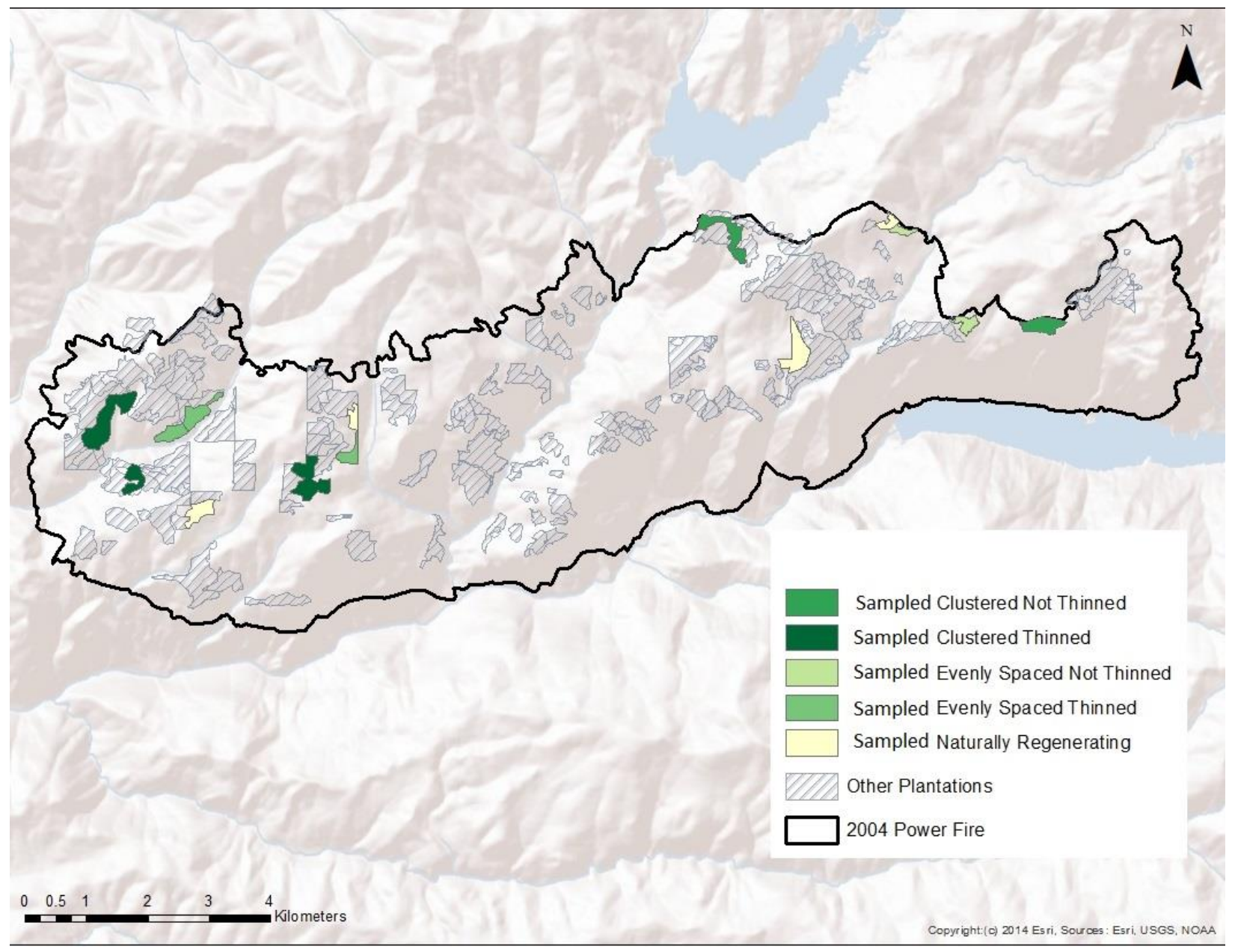

Figure 2. Sampling locations within the 2004 Power Fire perimeter in the El Dorado National Forest, California. 


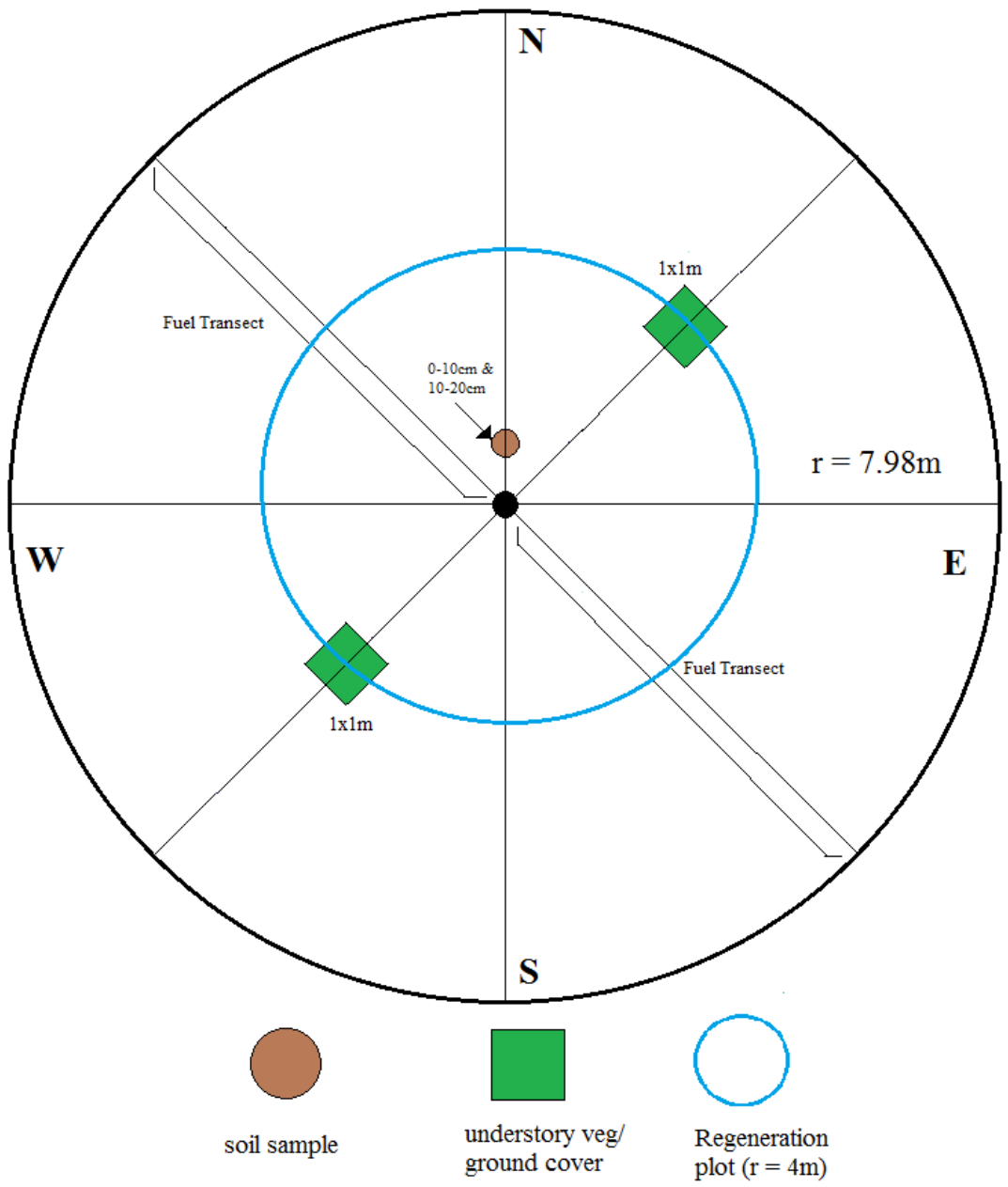

Figure 3. Sampling diagram for $200 \mathrm{~m}^{2}$ plots. $\mathrm{r}=$ radius; $\mathrm{N}=$ North, $\mathrm{E}=$ East, $\mathrm{S}=$ South, $\mathrm{W}=\mathrm{West}$. 

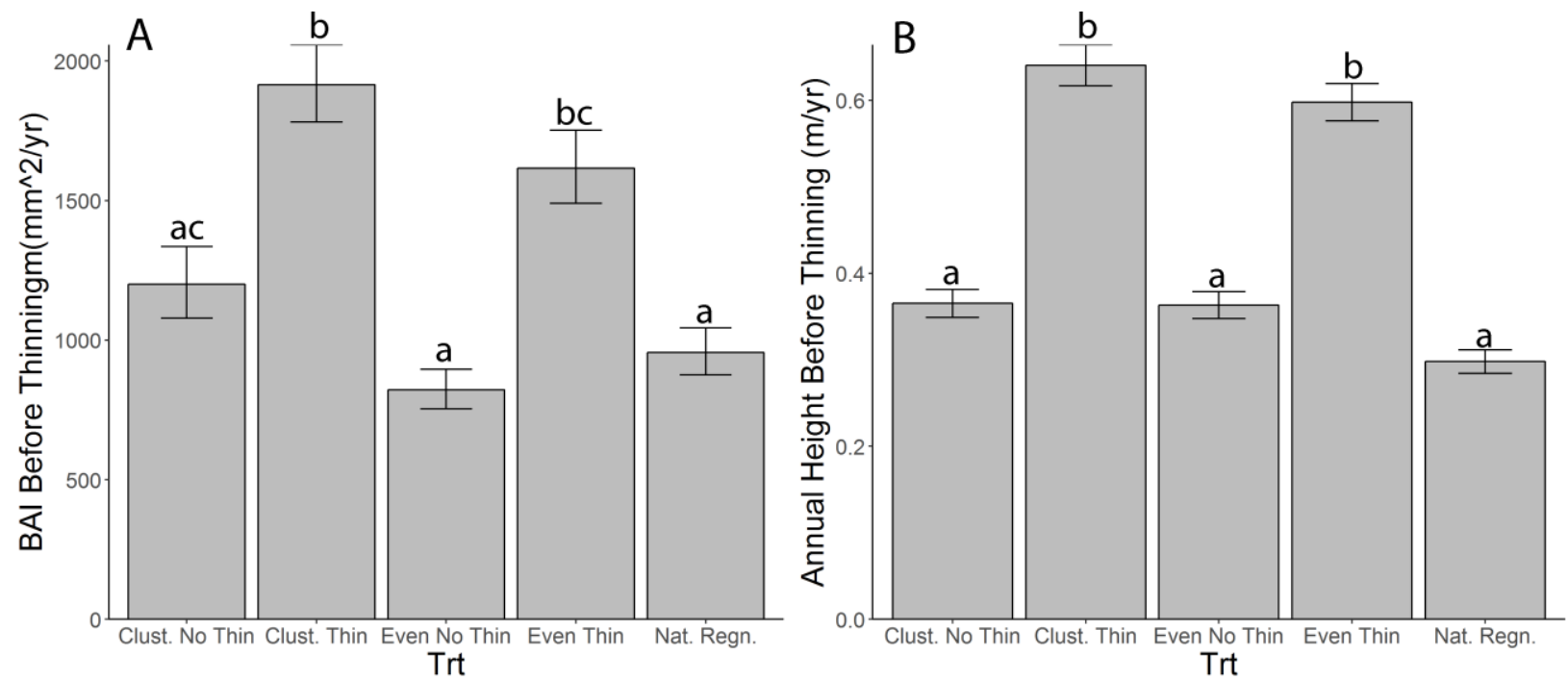

Figure 4. Incremental growth compared among all five treatment groups (Trt): (A) BAI before thinning and (B) annual height growth before thinning. Different lower case letters represent a statistical difference to the 0.05 significance level between treatments. Error bars represent $+/-1$ stand error (back transformed if a transformation was used).
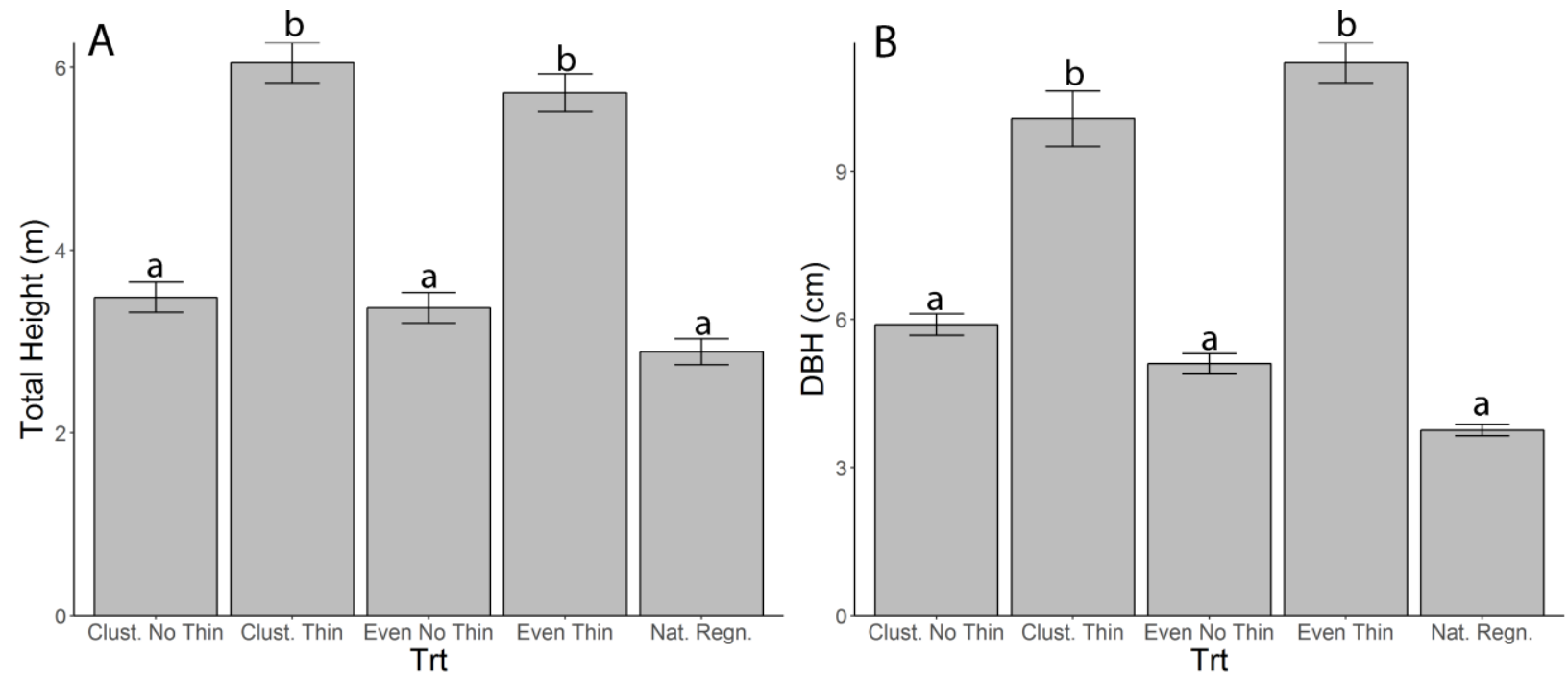

Figure 5. Mean total height (A) and DBH (diameter at breast height) (B) across all 5 treatments (Trt). Different lower case letters represent a statistical difference to the 0.05 significance level between treatments. Error bars represent $+/$ - one standard error. 


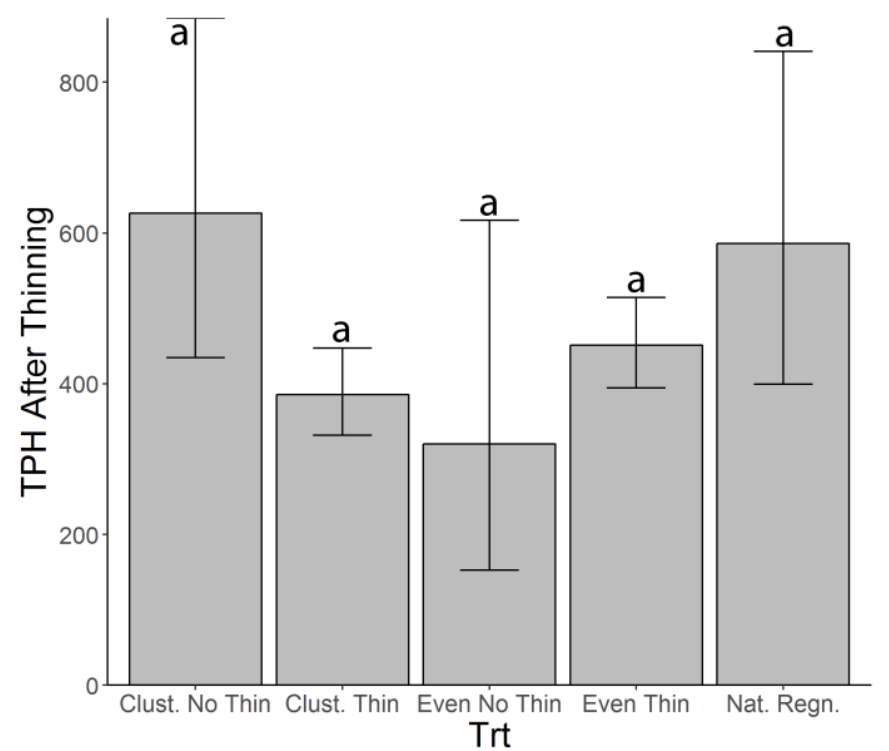

Figure 6. Trees per hectare (TPH) after thinning compared between all treatments (Trt). Same lower case letters represent no statistical difference to the 0.05 significance level between treatments. Error bars represent $+/-1$ back transformed standard error.

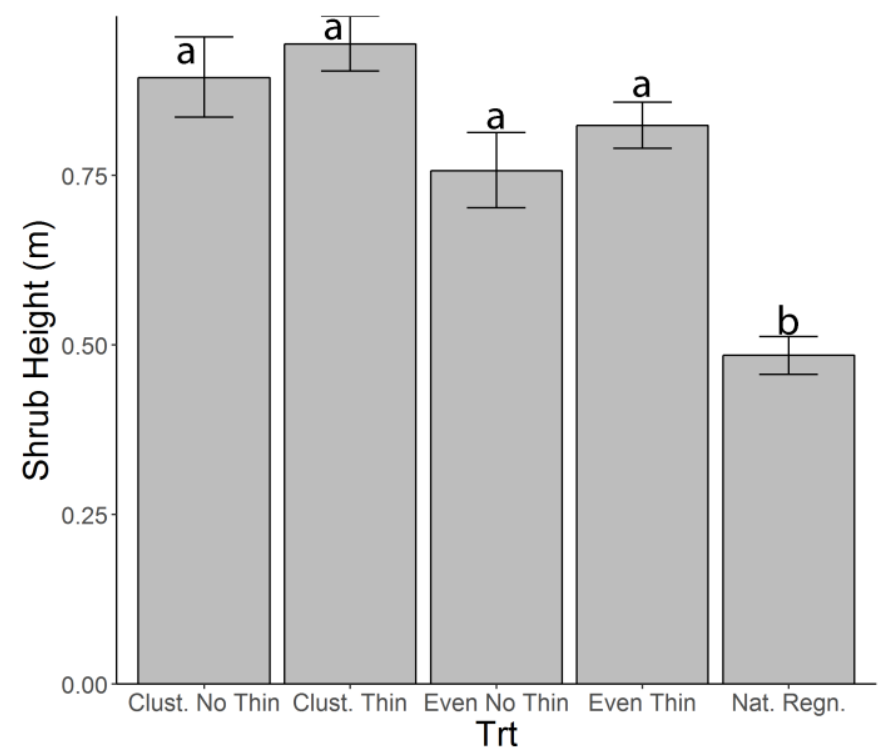

Figure 7. Shrub height compared between all five treatments (Trt). Different lower case letters represent a statistical difference to the 0.05 significance level between treatments. Error bars represent $+/$ - back transformed standard error. 


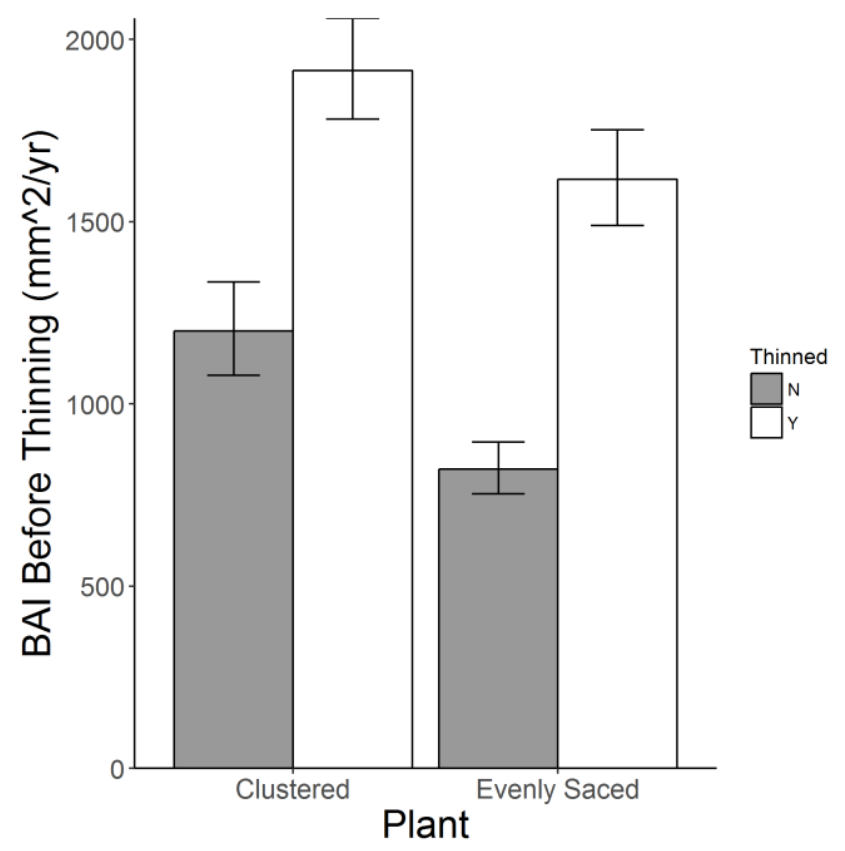

Figure 8. BAI before thinning compared among planting arrangement and thinning. Gray is not thinned and white is thinned. Error bars represent $+/-1$ back transformed standard error. BAI differed by planting arrangement $(\mathrm{p}=0.0427)$ and thinning $(\mathrm{p}=0.0006)$.
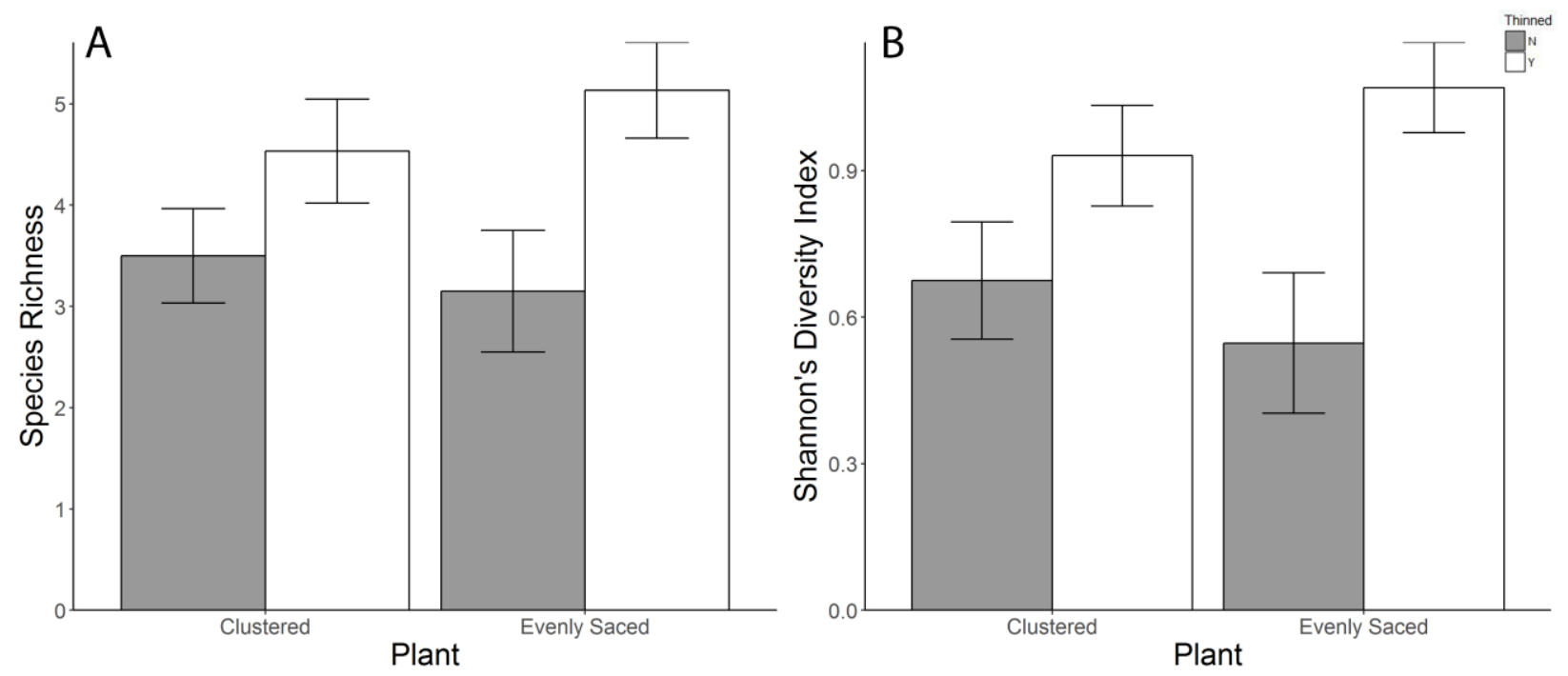

Figure 9. Species richness (A) and Shannon's diversity index (B) compared among planting arrangement and thinning. Gray is not thinned and white is thinned. Error bars represent $+/-$ stand error. Both species richness and Shannon's diversity index different among thinning $(p=0.0284$ and $\mathrm{p}=0.0559$, respectively). 


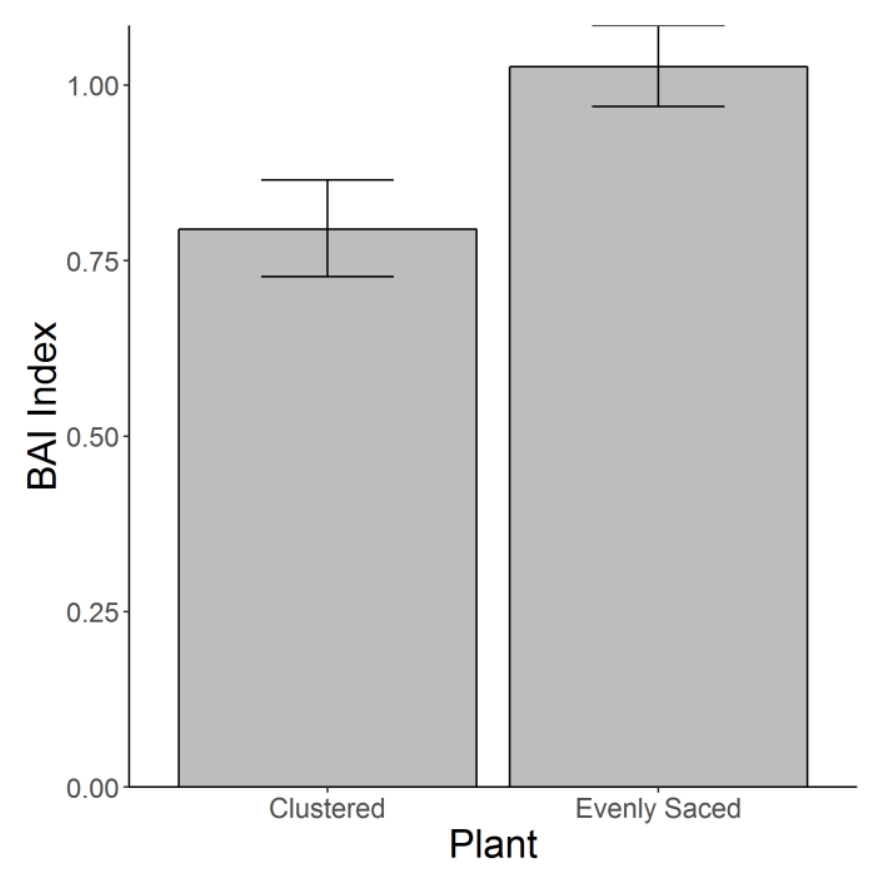

Figure 10. BAI thinning index ([BAI after thinning- BAI before thinning]/ BAI before thinning) compared between planting arrangement among plantations that were thinned. Error bars represent $+/-$ 1 back transformed standard error. There was a trend of BAI Index differing between planting arrangements $(\mathrm{p}=0.061)$. 


\section{Chapter 3: Modeling future stand development and fire risk of young, post fire plantations under different thinning and fuel treatments using FVS-FFE}

\subsection{Introduction}

Wildfires in the western United States are becoming more severe, larger, longer-lasting, and more destructive (Miller et al., 2009; North et al., 2015). In particular, plantations in fire frequent ecosystems are susceptible to higher severity fire compared to surrounding natural stands (Lyons-Tinsley and Peterson, 2012; Weatherspoon and Skinner, 1995; Zald and Dunn, 2018). This increased risk can be attributed to their dense, homogenous structure, which differs greatly from fire-resilient, pre-fire suppression conditions found in areas that historically had frequent fires, like the mixed conifer forests in the Sierra Nevada Mountains (Larson and Churchill, 2012; Stephens et al., 2008). Plantation structure creates a high continuity of surface and canopy fuels, which can support higher severity fires and encourage crown fire (North et al., 2019). Younger plantations are especially at risk; their increased density leads to a high accumulation of surface and canopy fuel, their lower canopy base height increases the likelihood of crown fires, and their thinner, less fire-resistant bark results in higher post-fire mortality (Thompson et al., 2011).

Science-based, active management of plantations can be employed to reduce their risk of highseverity fire. Planting trees in clustered groups resembling historical patterns and reducing the overall stocking rate are two suggested ways to reduce fuel connectivity and slow fire spread (North et al., 2019; Welch et al., 2016). Additionally, fuel reduction treatments, such as overstory thinning, mastication, and prescribed fire, are often necessary (Agee and Skinner, 2005). Overstory thinning reduces crown density, thus slowing the spread of fire through a canopy, but it does little to affect how fire spreads along the surface (Agee and Skinner, 2005). Mastication of small trees and shrubs can reduce connectivity from the surface to the crown via ladder fuels (Knapp et al., 2011; Kobziar et al., 2009; Reiner et al., 2012, 2009; Stephens and Moghaddas, 2005a). However, the addition of the small chipped fuels to the surface fuel bed can increase flame lengths and spread rate (Reiner et al., 2012). Therefore, the effectiveness of using 
only mastication is contested. Studies found it can both reduce (Reiner et al., 2012) and increase risk of crown fire (Kobziar et al., 2009). Other studies found mastication helped moderate some fire behavior metrics while exacerbating others (Knapp et al., 2011; Stephens and Moghaddas, 2005a). Therefore, mastication is often be combined with another fuel treatment, most effectively, prescribed fire (Kobziar et al., 2007; Reiner et al., 2012; Vaillant et al., 2009). Prescribed fire simultaneously reduces surface fuels (via consumption) and crown fuels (via consumptions and post-fire mortality), while promoting understory diversity and releasing nutrients back into the soil (Kane et al., 2010; Vaillant et al., 2009). While some damage from prescribed fire is inevitable in young plantations due to their low canopy base height and thin bark, fire's effect on fuel loading and thus future fire behavior often outweighs most of the damage it causes (Bellows et al., 2016).

Simulation modelling allows managers and researchers to tests the efficacy of different management techniques on plantation yield and reducing wildfire-risk over long periods of time without going through the time, costs, and logistics of implementing them in the field. The Forest Vegetation Simulator (FVS) and its Fire and Fuels Extension (FFE) is one effective tool to evaluate growth and fire behavior. FVS is a free, keyword based, spatially independent model, developed by the U.S. Forest Service that models stand level growth and mortality over time using tree and plot level variables collected in the field (Dixon, 2018). There are 20 different variants of FVS, each calibrated to specific regions in the United States. FVS allows the user to perform different management actions in the stand, including many types of thinning and fuels treatments. Additionally, the model is customizable, allowing the user to calibrate growth and mortality relationships. FVS-FFE is used to model fires in the stands, calculate simulated and potential fire behavior, and calculate fuels in the stand (Reinhardt and Crookston, 2003).

Creating and calibrating a model of stand development under different fuel treatment scenarios using FVS-FFE can provide a more comprehensive understanding of how stand growth influences fire behavior over time and help identify how different treatments will influence stand development and fire risk. Specifically, the objectives of this chapter are to 1) determine what combination of thinning intensity 
and fuel treatments best reduces crown fire danger and maximize growth in planted and naturally regenerating stands of mixed conifer forests and 2) determine the longevity of early management in the younger planted stands.

\subsection{Methods}

\subsubsection{Inventory and Fuel Data}

The same inventory data from chapter two was used for simulation of stand development. I categorized the 14 stands by the original management they experienced: six plantations had precommercial thinning (PCT), four plantations did not have PCT (non-PCT), and four stands naturally regenerated (NRG) after the fire. Due to FVS' spatial independence, I decided not to group the plantations by planting arrangement (clustered or evenly spaced), as any long term planting arrangement effects would be lost. There were five $200 \mathrm{~m}^{2}$ inventory plots in each stand, expect for two natural regenerating stands, which had seven and eight plots. Each plot had elevation, aspect, and slope measured; every tree in the plot taller than breast height $(1.37 \mathrm{~m})$ had species and DBH recorded. Total height and interwhorl height were measured for five randomly selected yellow pines in each plot; cores were also taken at breast height to determine yearly diameter growth to calibrate growth in FVS-FFE. To estimate fuel loading, two Brown's fuel transects were conducted along the northwest and southeast radii of the plots(Brown, 1974). Fuels are categorized by how long they take to respond to changing weather: 1 -hour fuels $(<0.64$ $\mathrm{cm}$ ) were counted for $1 / 8$ of the transect, 10-hour fuels $(0.64-2.54 \mathrm{~cm})$ were counted along $1 / 4$ of the transect, and 100-hour $(2.54-7.62 \mathrm{~cm})$ and 1000-hour $(>7.62 \mathrm{~cm})$ fuels were recorded for the full transect. The specific diameter of any 1000-hour fuels was recorded (Brown, 1974). Fuel bed, litter layer, and duff layer heights were measured at the $1 \mathrm{~m}$ point along these transects.

\subsubsection{Growth Simulations}

To simulate mixed conifer plantation conditions, I input field-collected stand and fuel information into FVS. I used the Western Sierra variant of FVS (Keyser and Dixon, 2018). Since FVS models growth at a stand level, I averaged elevation, slope, and aspect by plot among the stands. At the tree level, I entered species and DBH for all tree species. I input total height, annual height increments, and annual 
diameter increments when available so these values would help calibrate growth equations. Average incremental growth from 2014-2016 was used for both incremental height and diameter growth, as those years were common amongst all samples.

To better categorize stand development over 100 years, regeneration was incorporated into my model (Table 1). The Western Sierra variant of FVS uses the partial establishment models, which does not include automatic regeneration of non-sprouting species (Dixon, 2018). Therefore, regeneration had to be user-inputted. Initially, species-specific values were inputted based on my field-collected data and values from the literature; regeneration and subsequent stand development were then calibrated based on expert opinion (personal communication with Dr. Jainwei Zhang (United States Forest Service)). Final regeneration numbers were meant to accurately reflect different site conditions (namely light availability) and treatment effects. Survival rates for pine species were higher in simulations with prescribed burning to reflect those species affinity for exposed mineral soil (Zald et al., 2008). There were many young incense cedars and not many sugar pines in the sampled stands; therefore, regeneration of incense cedar was favored and sugar pine regeneration rates were kept low. For treated stands, I scheduled regeneration to begin 2 years after the initial treatment. I did this to avoid having all seedlings die in the prescribed burns, which happens one year after initial treatment (thinning and/or mastication). For untreated stands, regeneration amounts were delineated by age and trees per hectare (TPH). Regeneration increased with stand aged to reflect more mature trees, thus more seed sources. Regeneration decreased with increasing TPH, as competition for light and water increased (Table 1).

I modelled common silvicultural prescriptions to accurately represent different management scenarios for Sierra Nevada mixed conifer forests. I ran 12 different simulations on each stand, each a combination of an overstory thinning and a fuel treatment (Table 2). The overstory thinning treatments included thinning to stand density index (SDI) targets of 370, 495, and $618 \mathrm{TPH}(150,200$, and $250 \mathrm{TPA})$ and no-thinning scenario as control (Table 2). Reineke's SDI is useful metric as it is not related to age or site quality, so it can be used as a target over time and different sites (Shaw, 2005). I chose these thinning densities based on Long and Shaw (2012). They calculated 1360 TPH (550 TPA) as the maximum SDI 
for an even aged, mixed conifer stands in the Sierra Nevada. I chose the 495 and 618 SDI targets because they are below the $60 \%$ of $\mathrm{SDI}_{\mathrm{Max}}(815 \mathrm{TPH}, 330 \mathrm{TPA})$ where intense competition mortality begins, and above the $35 \%$ of $\mathrm{SDI}_{\text {Max }}(475 \mathrm{TPH}, 192.5 \mathrm{TPA}$ ) the lower limit of full site occupancy (Drew and Flewelling, 1979; Long and Shaw, 2012). I chose the target of 370 SDI to test an intensive thinning option that left the stand below full site occupancy. The three understory fuel treatments were mastication only, mastication with prescribed burning, and no treatment (Table 2). When simulating mastication, all trees below $20.3 \mathrm{~cm}$ DBH were masticated, except for in 2027 and 2037, where $7.6 \mathrm{~cm}$ and $12.7 \mathrm{~cm} \mathrm{DBH}$ were used as a cut-off to retain some trees in young stands. The masticated fuels were divided $70 \%$ into 10-hour (0.64- $2.54 \mathrm{~cm})$ and 30\% into 1-hour fuels $(<0.64 \mathrm{~cm})$ categories (Kane et al., 2009). All overstory thinning was a thin from below so harvesting began with the smallest diameter trees and continued until the target SDI was reached. In combination with mastication, the thinning lower DBH limit was the upper DBH cutoff for mastication; however without mastication, there was no lower DBH limit for thinning. To simulate prescribed burning, fires occurred one year after the mastication, which is common practice when using the two treatments together (Kobziar et al., 2009; Reiner et al., 2012). Fuel moisture conditions were selected from the literature (Johnson et al., 2011) to reflect typical prescribed burns in mixed conifer forests (Table 3). Each simulation lasted 100 years with 10 year cycle breaks. I simulated all thinning and fuels treatments in the following years: 2027, 2037, 2057, 2077, and 2097, or $10,20,40,60$, and 80 years into the simulation. One simulation without any management served as a control.

\subsubsection{Fuel model selection and fuel characteristics}

To simulate surface fuel conditions, standard fuel models developed by Scott and Burgan (2005) were used (Table 4). These standard fuel models have been calibrated for realistic fire behavior. Further, they perform comparably to custom fuel models, and can even do a better job with modeling fine fuels (Noonan-Wright et al., 2014). Additionally, it is recommended that the standard error of and stand's estimated fuel loads be within $20 \%$ of the stand's estimated mean fuel loading for the variation within a stand to be fully captured (Brown, 1974). My estimates did not meet this cutoff. 
Scott and Burgan's (2005) fuel model guide was reviewed to determine the best fuel model for each situation. These models are divided into several groups, including slash-blowdown (SB), timber litter (TL), timber understory (TU), and grass-shrub (GS). The groups represent what fuels will carry a fire in that stand. Each specific fuel model has values for the amount of fuel in the different size classes and fuel types (live and woody) and their corresponding surface area to volume ratios.

Fuel models were selected to represent initial conditions and changed during the simulation to continue to reflect fuel condition as the stand matures (Table 4; Fig. 1). For stands that had precommercial thinning, I used a combination of $25 \%$ grass and shrub model 2 (GS2), also known as "moderate load, dry climate grass-shrub", and 75\% timber litter model 4 (TL4) "small downed logs" for initial conditions. When the stands reached an SDI of 865 for unmanaged simulations or the third cycle for just thinned simulations, the $25 \%$ GS2 fuel model was retained but the TL4 fuel model was replaced by timber litter model 5 (TL5) "high load conifer litter". The TL4 fuel model represents small downed trees and the cut trees in the pre-commercial stands were left on site. "High load conifer litter" (TL5) portrays a more developed conifer stand as it accumulates fuels. For the remaining stands, the unthinned and naturally regenerating stands were divided into two groups based on density. The low density stands had very similar models to the pre commercially thinned stands, except that TL4 was replaced with TL3, "moderate load conifer litter", and the switch to TL5 was made in the fourth cycle for just thinning simulations. The low density stands had a large shrub component, like the thinned stands, but they did not have the same abundance of small downed logs. For the high density stands, a slightly different approach was used. The simulation began with timber understory model TU4, "dwarf conifer with understory" since it best represented dense stands consisting of many small trees with overlapping crowns and low height to live crowns. In these stands, the fuel model switches over to TL8 "long needle litter" when it reaches 988 SDI for no management simulations or at the third cycle for just thinning simulations. TL8 was chosen to represent fuels conditions in an older, denser conifer forests (Pawlikowski et al., 2019; Seli et al., 2008; Vaillant et al., 2009). The SDI cut offs for model switches were determined by simulating 
fire with the different fuel models over time and finding a point in time where a smooth transition between the chosen fuel models would happen.

Fuel models were also changed during the simulation to reflect the effect of different fuel management (Table 4). While, FVS accounts for fuel build up and decay as simulations run, masticated fuel beds and prescribed burns produce unique fuel characteristics that need to have their own fuel models. I decided to use slash and blowdown models SB1 "low load activity fuel" and SB2 "moderate load activity fuel or low load blowdown" to reflect post mastication fuel beds. These models have high amounts of fine fuels, which resembles a masticated fuel bed (Kane et al., 2009). Additionally, these two models are frequently recommended to adequately portray masticated fuel beds (Knapp et al., 2011; Kreye et al., 2014; Reiner et al., 2012; Schmidt et al., 2008). Timber litter model 1 (TL1), also known as "low load compact conifer litter", was used to reflect post prescribed burn conditions, as it is recommended by Scott and Burgan (2005) and is frequently used for modeling post-fire conditions (Reiner et al., 2012; Schmidt et al., 2008; Scott and Burgan, 2005).

Canopy base height (CBH) and canopy bulk density (CBD) are two stand level characteristics that influence fire behavior. $\mathrm{CBH}$ is the distance from the ground to the level of the crown where the density of fuels first surpasses $0.011 \mathrm{kgm}^{-3}$, the threshold of fuel density where a fire can travel vertically through the canopy (Reinhardt and Crookston, 2003; Smith, 2009). CBD is a measurement canopy fuels that will be consumed in a crown fire: mainly foliage and 1 hour fuels (Smith, 2009). To calculate it, first crown mass for all trees is calculated based on species, $\mathrm{DBH}$, height, crown ratio, and dominance position (Reinhardt and Crookston, 2003). Then FVS-FFE finds the "effective canopy bulk density" by finding the maximum $4 \mathrm{~m}$ running average for 0.3 thick canopy fuel layers (Reinhardt and Crookston, 2003).

\subsubsection{Fire Weather}

To model severe fire weather conditions, I used weather data from the closets Remote Automatic Weather Station (RAWS) to the study sites, Beaver Camp Loc (Station ID: 042601). Daily weather data was downloaded from October to May, the common fire season for the Sierra Nevada Mountains, for all available years (1996-2018). From that daily weather data, energy release component (ERC) and potential 
fuel moistures for different fuel size classes were calculated using Fire Family Plus (Bradshaw and Jolly, 2014). ERC is a measure of fire intensity as a function of fuel moisture and is often used as an index for fire severity (Knapp et al., 2011; Kobziar et al., 2009; Safford et al., 2012). Average weather (temperature, wind speed) and fuel moisture values corresponding to the $97^{\text {th }}$ percentile in ERC were used to represent severe fire weather conditions (Table 3).

\subsubsection{Statistical Analysis}

To assess how growth and fire behavior differed among the fuel treatments, thinning intensities and original management, I performed three-way ANOVAs on the simulation outputs using those metrics as the three factors. For stand growth, I only included trees over $20 \mathrm{~cm}$ (to avoid any impact of small trees from regeneration) to calculate basal area per hectare, and quadratic mean diameter (QMD) for each stand at the end of the simulation. All fire behavior data was taken from the FVS potential fire report, which determines fire behavior and effects if fire burned through the stand based on the weather and fuel conditions assigned. None of the fire effects from the potential fire report influence subsequent stand development. After plotting several fire behavior variables over the length of the simulation, I observed a common pattern among all simulations where fire behavior increased in the early years, then stabilized to low severity values with little variation (Fig. 2, 3, 4). Therefore, to analyze fire behavior, I decided to identify the years for each simulation where each variable reaches the "stable level" of surface fires, low flame length, and low mortality. I first analyzed the year where the fire type transitions to surface fire. Fires are categorized into four different categories: active crown fire, passive crown fire, condition crown fire, and surface fire. In an active crown fire, the fire spreads through the canopy, burning and killing almost all trees in the stand. In passive crown fires, individual trees will torch and have their crowns burn, but the fire does not spread through the crown. In a conditional crown fire, if the fire starts as a surface fire it will most likely stay there, but if an adjacent stand has a crown fire, it may spread into the crown of the stand. Surface fires are the least severe, stay on the ground, and usually do not kill many mature trees (Dixon, 2018). To analyze mortality, I looked at when percent basal area mortality went below 25\%, a common cutoff for low severity fires (Hann et al., 2008). To analyze flame length, I tested when canopy 
base height exceeded flame length. Crowning index followed a different pattern from the other variables, so it was tested accordingly. Crowning index is the required wind speed at $6 \mathrm{~m}$ above ground to sustain an active crown fire. Consequently, as crowning index increases fire risk decreases. To test the overall pattern of crowning index, I tested its value at the end of the simulation.

To better understand the relationship between fire behavior and stand development I summarized and graphed fire effects (mortality), fire behavior (flame length, spread rates, fire type) and fuel variables (canopy base height, and bulk density) over the length of the simulation. For each prescribed fire, I summarized the percent of the total trees killed in each prescribed fire and compared these values across original management and thinning intensity. I summarized surface and total flame length and spread rate for all simulation years and tested them among the fuel treatments. Surface flame length and spread rate refers to fire behavior when consuming surface (ground) fuels. Total flame length and spread accounts for fire spread into trees' crowns (Reinhardt and Crookston, 2003). I tested all three way ANOVAs using the “aov” function in R Studio (RStudio Team, 2018). I tested for normality using a QQ plot and ShapiroWilk test. If normality was not met, I performed different transformation on the data until it was. Tukey's HSD was used for all post hoc testing.

\subsection{Results}

\subsubsection{Stand Growth}

The difference in final basal area and QMD were best explained by thinning intensity and whether the simulation had a prescribed burn. Final basal area per hectare differed among fuel treatment $(\mathrm{p}<0.0001)$ and thinning intensity $(\mathrm{p}<0.0001)$, but the effect of fuel treatment depended on the thinning intensity ( $p<0.0001$ ) (Tables $5 \& 6$, Fig. 5A). Within the 370 SDI and 495 SDI thinning intensities there was no significant effect of fuel treatment on basal area. However, the mastication with prescribed burn fuel treatment resulted in less basal area than the mastication only fuel treatment and no fuel treatment in the 618 SDI thinning and no overstory thinning scenarios (Fig 5A). Within the different fuel treatments, responses to thinning intensities differed. In the mastication with prescribed burning fuel treatment the 
only significant differences between thinning intensities were among nonadjacent intensities (e.g. 370 SDI and 618 SDI, not 370 SDI and 495 SDI), with the larger SDI targets having greater basal area. A similar pattern occurred with mastication only and no fuel treatment scenarios, but all differences among thinning intensities were significant (Fig. 5A). Overall, final basal area increased as thinning intensity decreased (370 SDI being the most intense and no overstory thinning being the least intense) and mastication with burning had the lowest final basal area compared to mastication only and no fuel treatment simulations (Table 6).

QMD had the opposite patterns of basal area, differing among thinning intensities $(\mathrm{p}<0.0001)$ and original management $(\mathrm{p}<0.0001)$ (Tables $5 \& 7$ ). The effect of fuel treatment depended on the thinning intensity $(\mathrm{p}=0.0373)$ (Table 5, Fig. 5B). Within the different thinning intensities, QMD did not differ between fuel treatments, expect when there was no overstory thinning (Fig. 5B). Under no-thinning scenarios, mastication with prescribed burning resulted in larger QMD than the no fuel treatment simulations. Within the mastication only and no fuel treatments, QMD increased with thinning intensity only among a few non-adjacent thinning intensities (Fig. 5B). For example, in the mastication only fuel treatment, 370 SDI was only different from 618 thin and no thinning, but not different from the 495 SDI simulations. Within the mastication with burning treatment there were no differences in QMD between thinning intensities (Fig. 5B). Overall, QMD increased as thinning intensity increased; the no thinned stands had QMDs that were $11.5 \%$ smaller than the 370 SDI simulations (Table 7). The naturally regenerating stands had $11.8 \%$ larger QMD than both plantation types (Table 7).

\subsubsection{Fire Behavior}

Several factors influenced what simulation year surface fires began. The timing when fire risk decline differed among fuel treatments $(\mathrm{p}<0.0001)$, thinning intensity $(\mathrm{p}=0.0005)$, original management $(p<0.0001)$, and the interaction of fuel treatment and thinning intensity $(p=0.0213)$ (Table 5, Fig. $2 \&$ 5C). Within different thinning intensities, fuel treatment only affected simulation year when surface fires began for the no overstory thinning simulations; stands that experienced mastication with burning transitioned to surface fires 14 and 23 years earlier than the mastication only treatment and the no fuel 
treatment simulations, respectively. Thinning intensity only affected when surface fire began when no fuel treatment was simulated (Fig. 5C). Within the no fuel treatment simulations, all three thinning intensities reached surface fires sooner than the no overstory thinning simulations (Fig. 5C). Overall, mastication with burning resulted a transition to surfaces fires 10 years sooner than mastication only and no fuel treatment (Fig. 2). For overall thinning intensity, only the 370 SDI transitioned to surface fires before no overstory thinning simulations. The PCT plantations reached surface fire 10 years sooner than both the non-PCT plantations and the natural regenerating stands (Fig. 2).

Simulation year when basal area mortality went below $25 \%$ was reduced the most by prescribed fire. It differed among fuel treatments $(\mathrm{p}<0.0001)$, thinning intensities $(0.0175)$, and original management $(\mathrm{p}<0.0001)$ (Table 5, Fig. 3). The mastication with burning fuel treatment went below $25 \%$ basal area mortality 11 and 17 years before the mastication only and no fuel treatment, respectively; mastication only went below $25 \%$ mortality 6 years before the no fuel treatment simulations (Fig. 3). Among the different thinning intensities, the only significant difference was that the 370 SDI thinning intensity went below $25 \%$ basal area mortality 5 years before the no overstory thinning simulations (Fig. 3). The PCT plantations went below $25 \%$ basal area mortality 9 and 5 years sooner than the non-PCT plantations and the naturalyl regenerating stands, respectively. The natural regenerating stands went below $25 \%$ mortality 4 years sooner than the non-PCT stands (Fig. 3).

Age when canopy base height went above flame length followed the same patterns as the age when surface fire began. It differed among fuel treatment ( $p<0.0001)$, thinning intensity $(p=0.0016)$, and original management $(\mathrm{p}<0.0001)$, and there was a trend in the interaction of fuel treatment and thinning intensity $(\mathrm{p}=0.0513)$ (Table 5, Fig. $4 \& 5 \mathrm{D})$. The interaction followed the same trends as age when fire type transitioned to surface fire (Fig. 5D). Overall, mastication with burning resulted in canopy base height exceeding flame length 10 years sooner than both mastication only and no fuel treatment simulations (Fig. 4). Only the 370 SDI thinning level reached canopy base height above flame length 10 years sooner than the no overstory thinning simulations (Fig. 4). The PCT plantations reached canopy 
base height above flame length 11 and 7 years sooner than that non-PCT plantations and the natural regenerating stands, respectively (Fig. 4).

The pattern of final crowning index was affected by thinning targets more than the other fire behavior variables. Final crowning index differed among fuel treatment $(\mathrm{p}<0.0001)$, thinning intensity $(\mathrm{p}$ $<0.0001)$, original management $(\mathrm{p}=0.0003)$, and the interaction between fuel treatment and overstory thinning ( $\mathrm{p}=0.0073$ ) (Table 5, Fig. $6 \& 5 \mathrm{E})$. When comparing within thinning intensity, I only found a difference between fuel treatments in the no overstory thinning scenarios. When no overstory thinning was simulated, mastication with burning resulted in a significantly higher final crowning index than mastication only and no fuel treatment only in the no overstory thinning simulations (Fig. 5E). Within the no fuel treatment simulations, there were difference among all the thinning intensities expect when comparing 618 SDI and 495 SDI (Fig. 5E); when comparing thinning intensities within mastication simulations, results were very similar. However, within the mastication with burning there were very few significant differences between thinning intensities (Fig. 5E). In all cases of significant difference, the more intensive thinning treatment had a higher final crowning index. Over all, mastication with burning had higher final crowning indices than the mastication only and no fuel treatment simulations (Fig. 6). All overstory thinning treatments were different from each other, with the more intensive thinning resulting in the higher crowing index (Fig. 6). The natural regenerating stands had a higher crowing index than both plantation types (Fig. 6).

\subsubsection{General Fire Behavior and Stand Structure Patterns}

When comparing percent mortality following prescribed burns between thinning targets, I only found significant differences during the last burn. In 2097, the prescribed burn killed more trees in the 618 SDI and no overstory thinning treatment than the 370 SDI treatment (Table 8). When comparing mortality from prescribed burns across original management, the PCT plantation had slightly less mortality than the other treatments in the first two buns. In 2027 the non-PCT plantation had about $8 \%$ less mortality than the NRG stands and in 2037, the NRG stands had about $2 \%$ less mortality than the non-PCT plantations (Table 8). A consistent pattern was found when comparing differences in surface 
and total fire behavior. When comparing total spread rate and flame length, mastication with burning had lower values than both mastication only and no fuel treatment; there was no different between mastication only and no fuel treatment (Table 9). When comparing surface behavior, mastication with burning was still lower than the other two fuel treatments, but mastication only was also significantly lower than the no fuel treatment (Table 9).

\subsection{Discussion}

Management effected basal area per hectare predictably. Overstory thinning decreased basal area but increased QMD (Table 6). All the thinning and fuel simulations were from below, making it unlikely for any regeneration to make it to the overstory, resulting in a lower overstory basal area as thinning intensity increased. While the overall stocking decreased with thinning, tree size increased as overstory thinning intensity increased. Ponderosa pine and mixed conifer stands show a positive growth response to thinning because thinning reduces competition for water, light, and nutrients and allows for more growing space (Dore et al., 2016; Feeney et al., 2011; Zhang et al., 2013a, 2013b).

Mortality from the mastication with burning treatment provided growth benefits to the stands (Table 7). Smaller trees have a lower chance of surviving fires than larger trees, so prescribed fires can shift dimeter distribution upward (van Mantgem et al., 2011). Mortality from prescribed burning is unavoidable; in fact, one of its benefits is that it reduces stem density providing a competition release for the remaining trees (North et al., 2007; Schmidt et al., 2006; van Mantgem et al., 2011). The effect of mastication with burning was only seen in the 618 SDI and no overstory thin simulations for basal area and only the no overstory thinning simulations for final QMD (Fig. 5A \& 5b). This could be due to the mortality response of different thinning intensities to prescribed burning. The prescribed fires killed more trees in the 618 SDI and the no thin simulations compared to the 370 SDI simulations (Table 8 ). The percent mortality from prescribed burning is in line with other studies. Percent mortality from the simulations of prescribed fire was the highest in the earliest fire (2029), ranging from 33-64\%, decreased to $19-44 \%$ for the next prescribed fire in 2039 , and stayed below $22 \%$ for all subsequent prescribed fires 
(Table 8). Reiner et al. (2012) performed and mastication and burning study in a 25 year old plantation, and found mortality from prescribed burning between $27-49 \%$, which overlaps the 33-64\% mortality observed in this study.

One unexpected result was the effect of original management on final QMD. When comparing the stands in 2017, the PCT plantations had larger diameter than the non-PCT plantations and natural regeneration stands. However, at the end of the simulation, the natural regenerating stands' QMD were about $8 \mathrm{~cm}$ larger than the PCT and non PCT plantations (Table 7). In general, the thinned stands had steeper slopes than the other two original management groupings. High slopes often have a negative effect on tree growth due decreasing soil depth (Stage, 1976); this relationship is expressed in FVS's diameter growth equations. It predicts more diameter growth on gentler slopes (Dixon, 2018; Keyser and Dixon, 2018).The small differences in slope could manifest themselves over time.

While the fuels and overstory thinning treatments had a large effect on fire behavior, all stands, regardless of silvicultural prescription, experienced a similar pattern in fire behavior over 100 years. Fire severity and intensity reached a maximum usually within the first 10 to 50 years of the simulation, but eventually decreased so that surface fires were more common, flame lengths were below canopy base height, and mortality was below $25 \%$ (Figs. 2, 3, 4). This pattern is a consequence of the stand structure and development in even aged plantations. When the stands are young, the trees have low canopy base heights, leaving them susceptible to crown scorch, even with low flame length. The horizontally homogenous nature of a plantation allows for the fire to spread throughout the stand, resulting in high mortality (North et al., 2019). This pattern has been seen in young ponderosa pine and mixed conifer plantations (under 50 years), both modeled and observed (Stephens and Moghaddas, 2005b; Thompson et al., 2011; Zald and Dunn, 2018). However, as the stand grows, those canopy fuels move away from the ground, increasing canopy base height (Fig. 7). The uniform distribution of growth in a plantation usually results in one main size class, so there will not be several layers of vertical stratum lowering the position of canopy base height. Regeneration can also affect canopy base height. If regeneration is dense enough it can lower than canopy base height and help carry a fire from the surface to the canopy, torching and 
killing mature trees. The simulated overstory thinning and fuels treatments removed regeneration, as they all focused on small trees, preventing them from becoming a ladder fuel. Regeneration in the simulations without any management did not keep canopy base height low enough to maintain severe fire behavior though the full simulation; though it did delay the onset of canopy base height overtaking flame length (Fig. 4).

High canopy base heights have been noted in an even-aged mixed conifer site before. Stephens and Moghaddas (2005b) studied mature (80-100 years old), even aged stands that naturally regenerated after railroad logging and did not experience any silvicultural treatments. They found high canopy base heights in these stands, and therefore low potential for crown fire (North, 2012). While not a plantation, the stand structure is like what one would find in plantations; in addition, this study did include some even aged stands that naturally regenerated after a fire. However, there are other factors besides canopy base height that control whether a fire will travel into a crown. Downed logs and sags can also be ladder fuels, and extreme winds can also carry a surface fire to the crown (Zald and Dunn, 2018). Creating a fire resilient forest stand cannot simply rely on the fact that canopy base heights will eventually increase over time in a plantation.

The main variables that influence fire behavior in FVS-FFE, such as surface fuel loading, canopy base height, and canopy bulk density, can be modified by various silvicultural treatments (Agee and Skinner, 2005). A consistent interaction between thinning intensity and fuel treatment was observed for most of the fire behavior variables (Table 5, Fig. 5). There were more significant effects of fuel treatment in no overstory thinning simulations. This could be due to the nature of the stand structure and how the thinning was performed. All thinnings were from below, so they removed the smallest trees first. Smaller trees can act as ladder fuels which can carry fire up into tree canopies (Agee and Skinner, 2005). Simulations without overstory thinning needed something else to reduce ladder fuels, which mastication and prescribe burning can do (Stephens and Moghaddas, 2005a).

Mastication with prescribed burning was the most effective fuel treatment because how it altered surface fuels and flame lengths (Fig. 2 -5). After a prescribed burn, most of the surface and ladder fuels 
have been consumed (Agee and Skinner, 2005; Stephens, 1998; Vaillant et al., 2009). This decreases flame length and reduces the risk of crown fires as fires on the surface cannot travel up the canopy (Vaillant et al., 2009). This reduction crowning drastically reduces fire caused mortality (Fig. 3). The effectiveness of prescribe burning can be seen in the interaction among thinning and fuel treatments in the transition to surface fires (Fig. 5C). Using prescribed fire with mastication caused the transition to surface fires to happen so quickly and consistently, that tree density did not matter. Prescribed burning is often found to be the most effective treatment for reducing surface fuel loading and thus reduce fire risk in Sierra Nevada plantations (Kobziar et al., 2009; Reiner et al., 2012; Schmidt et al., 2008; Stephens and Moghaddas, 2005a).

The differences between the mastication only and the no fuel treatment simulations were minimal (Figs. 2, 4, 6). One of main benefits of mastication is how it removes ladder fuels (Knapp et al., 2011; Stephens and Moghaddas, 2005a). However in an even aged plantation, where most trees are about the same size, there are not many ladder fuels, diminishing the benefits of mastication (Kobziar et al., 2009). Also, mastication does not remove the fuels from the stand, it just moves them to the surface and decreases their size. Both Kobizar et al. (2009) and Reiner et al. (2012) found that masticated fuel beds produced longer flame lengths than stands without fuels treatments when modeling fire behavior in young Sierra Nevada pine plantations.

Despite high total flame lengths, masticated fuels reached basal area mortality under $25 \%$ earlier than the no fuel treatment simulations (Fig. 3). Both the average surface flame length and average surface spread rate across all years in masticated fuel beds was smaller than the no fuel treatments, while there was no difference among total flame length and spread rate (Table 9). These differences in surface fire behavior could result in less scorch damage in the scenarios with masticated fuel beds, and thus less mortality. Both laboratory and field studies suggest that masticating fuels results in denser fuel beds than can dampen surface flame lengths and spread rates (Knapp et al., 2011; Kreye et al., 2011). Masticated fuel beds can be quite difficult to model (Knapp et al., 2011; Kreye et al., 2014). The fuel particles often have an irregular shape which can have complicated interactions with fuel moisture and decay (Kreye and 
Varner, 2007; Kreye et al., 2014). A development of a fuel model specifically designed for masticated fuel beds would improve subsequent studies modeling fire behavior under different fuel treatments.

The largest impact of overstory thinning intensity on fire behavior was seen on crowning index. As thinning intensity increased, crowning index increased (Fig. 6). As the stand density decreases from thinning, the density of fuels in the canopy will also decrease simply due to less trees being present (Fig. 8). A decrease in canopy bulk density results in less canopy fuel continuity, which ultimately decreases the occurrence and severity of crown fires (Agee and Skinner, 2005). While thinning target influenced other fire behavior variables due to removing ladder fuels, usually the only difference found between the targets was among the most intense thinning target, 370 SDI, and no thinning. Also, the difference between them was usually only a 5-10 year improvement on when fire behavior reached low risk levels, while mastication with burning often provided a 15-20 year improvement. The more the stands were thinned, the larger the trees became (Table. 7). Larger trees will have thicker bark which is more resistant to fire (Hood et al., 2018; Pellegrini et al., 2017). Thinning the overstory to below full site capacity was required to produce most effective changes in mortality from fire, suggesting it is not a viable option to reduce crown fire risk. Several other studies have found similar results of overstory thinning having minimal reductions in fire behavior alone (Agee and Skinner, 2005; North et al., 2009; Stephens and Moghaddas, 2005a). This is likely due to the fact that overstory thinning will not decrease surface fuels, in fact it can increase surface fuels when logging slash is left on the ground.

In addition to the silvicultural impacts on fire behavior, several differences among the original management scenarios were found. These differences can be attributed to original stand structure and how they grew over time. The stands with PCT reached low mortality and achieved a canopy base height above flame length sooner than the other original management scenarios (Figs. $3 \& 4$ ). While at the end of the simulation the natural regenerating stands had larger trees, the stand with PCT started out with larger trees. This switch from the PCT trees to the natural regenerating trees as the largest likely happened after fire behavior decreased. Like with thinning intensity, this response could also be linked to bark thickness. Larger trees have thicker bark, which protects the vascular cambium from heat and scorch 
damage from fire and is a common adaptation in trees in fire dependent ecosystems (Pellegrini et al., 2017).

There are some modeling limitations with FVS-FFE that should be taken into consideration. As mentioned earlier, the lack of a full establishment model for all variants and a fuel model for masticated fuel beds create complications for accurately modeling fire behavior (Dixon, 2018; North et al., 2009). Another limitation of FVS is its spatial independence. The spatial arrangement of trees can greatly effect growth and fire behavior (Churchill et al., 2013; Larson and Churchill, 2012; Stephens et al., 2008; Ziegler et al., 2017). In addition to this, post-fire plantations have included experimentation with planting trees in a clustered arrangement to mimic this pattern (North et al., 2019). The plantations used in this study were a mix of clustered and evenly spaced trees but were not analyzed along these lines due to FVS's lack of spatial dependence. Another spatial variable which is not included in FVS is landscape fire behavior dynamics. The spatial arrangement of stands and silvicultrual treatments across a landscape can affect how a fire spreads (Finney, 2001). The landscape aspect of fire behavior was outside of the scope of this project but is an important factor consider when interpreting results. Stands that are predicted to have conditional crown fires are more likely to have crown fire spread if an adjacent stand has an active crown fire (Reinhardt and Crookston, 2003). Lastly, shrubs have been proven to be a factor that can impact plantation growth in the Sierra Nevada; often controlling for shrubs can be one of the most important factors in plantation survival (McDonald and Fiddler, 2010; Zhang et al., 2008). FVS has a submodel for shrubs and understory cover, but it is not currently developed for the western sierra variant or linked with the FFE extension, and therefore not used in this project. An expansion of this submodel would greatly help in modeling plantation and post fire growth in the Sierra Nevada.

\subsection{Conclusions}

Stand development and the various silvicultural treatments all interacted to create a variety of simulations outcomes. While the overall pattern of decreasing canopy base heights over time eventually lead to a decrease in fire behavior metrics regardless of treatment, the amount of time required to reach 
these decreased crown fire risks changed with treatment. Using prescribed burns reduced flame lengths so drastically, that canopy base height quickly exceeded flame length. Additionally, performing intensive thinning reduced risk of active crown fires spreading though the stand. These results suggest that treating stands early is most important for reducing fire risk, as that is when the risk is the highest. Further research into specific timing of treatments will help answer this. Prioritizing prescribed burning, when possible, and thinning from below are the most effective ways to quickly improve fire resistance in mixed conifer plantations. However, the most effective treatments are not without disadvantages. The prescribed burns killed many trees, reducing overall stocking. The most intensive thinning treatment provided the best reduction of fire behavior but was also below full stocking level. FVS is not without drawbacks, either. It can be sensitive to certain inputs, like regeneration and fuel models and cannot not incorporate all the complexity of fire, like spatial arrangement of trees. However, it provides a good tool for evaluating overall trends of stand development and how to alter them to reduce fire risk. Identifying the most effective stand management techniques to create fire resilient stands has become increasingly important in the past few decades. More than half of the Forest Service's plantations in the Sierra Nevada mountains established from 1998 to 2016 have not been pre-commercially thinned, and $38 \%$ of them have not experienced any competition release (North et al., 2019). These young, dense stands pose a large crown fire risk, and if they are left unmanaged, this risk will continue for several decades. 


\subsection{Works Cited}

Agee, J. K., \& Skinner, C. N. (2005). Basic principles of forest fuel reduction treatments. Forest Ecology and Management, 211(1-2), 83-96. https://doi.org/10.1016/j.foreco.2005.01.034

Bellows, R. S., Thomson, A. C., Helmstedt, K. J., York, R. A., \& Potts, M. D. (2016). Damage and mortality patterns in young mixed conifer plantations following prescribed fires in the Sierra Nevada, California. Forest Ecology and Management, 376, 193-204. https://doi.org/10.1016/j.foreco.2016.05.049

Bradshaw, L., \& Jolly, M. (2014). FireFamilyPlus.

Brown, J. K. (1974). Handbook for Inventorying Downed Woody Material. USDA For. Serv. Gen. Tech. Rep. https://doi.org/10.1017/CBO9781107415324.004

Churchill, D. J., Larson, A. J., Dahlgreen, M. C., Franklin, J. F., Hessburg, P. F., \& Lutz, J. A. (2013). Restoring forest resilience: From reference spatial patterns to silvicultural prescriptions and monitoring. Forest Ecology and Management, 291, 442-457. https://doi.org/10.1016/j.foreco.2012.11.007

Dixon, G. (2018). Essential FVS : A User's Guide to the Forest Vegetation Simulator, 226. https://doi.org/10.1007/978-3-319-23883-8

Dore, S., Fry, D. L., Collins, B. M., Vargas, R., York, R. A., \& Stephens, S. L. (2016). Management impacts on carbon dynamics in a sierra Nevada mixed conifer forest. PLoS ONE, 11(2), 1-22. https://doi.org/10.1371/journal.pone.0150256

Drew, T. J., \& Flewelling, J. W. (1979). Stand Density Management : an Alternative Approach and Its Application to Douglas-fir Plantations. Forest Science, 25(3), 518-532.

Feeney, S. R., Kolb, T. E., Covington, W. W., \& Wagner, M. R. (2011). Influence of thinning and burning restoration treatments on presettlement ponderosa pines at the Gus Pearson Natural Area. Canadian Journal of Forest Research, 28(9), 1295-1306. https://doi.org/10.1139/x98-103

Finney, M. A. (2001). Design of regular landscape fuel treatment patterns for modifying fire growth and behavior. Forest Science, 47(2), 219-228.

Hann, W. J., Shlisky, A., Havlina, D., Schon, K., Barrett, S. W., DeMeo, T. E., ... Frame, C. K. (2008). Interagency Fire Regime Condition Class Guidebook (FRCC) guidebook. Homepage of the Interagency and The Nature Conservancy Fire Regime Condition Class website, USDA Forest Service, U.S. Department of the Interior, The Nature Conservancy, and Systems for Environmental Management. Retrieved from www.frcc.gov

Hood, S. M., Varner, J. M., Van Mantgem, P., \& Cansler, C. A. (2018). Fire and tree death: Understanding and improving modeling of fire-induced tree mortality. Environmental Research Letters, 13(11). https://doi.org/10.1088/1748-9326/aae934

Johnson, M. C., Kennedy, M. C., \& Peterson, D. L. (2011). Simulating fuel treatment effects in dry forests of the western United States: testing the principles of a fire-safe forest. Canadian Journal of Forest Research, 41(5), 1018-1030. https://doi.org/10.1139/x11-032

Kane, J. M., Morgan Varner, J., Knapp, E. E., \& Powers, R. F. (2010). Understory vegetation response to mechanical mastication and other fuels treatments in a ponderosa pine forest. Applied Vegetation Science, 13(2), 207-220. https://doi.org/10.1111/j.1654-109X.2009.01062.X

Kane, J. M., Varner, J. M., \& Knapp, E. E. (2009). Novel fuelbed characteristics associated with mechanical mastication treatments in northern California and south-western Oregon, USA. International Journal of Wildland Fire, 18(6), 686-697. https://doi.org/10.1071/WF08072

Keyser, C. E., \& Dixon, G. E. (2018). Western Sierra Nevade ( WS ) Variant Overview- Forest Vegetation Simulator. Fort Collins, CO: U. S. Department of Agriculture, Forest Service, Forest Management Service Center.

Knapp, E. E., Varner, J. M., Busse, M. D., Skinner, C. N., \& Shestak, C. J. (2011). Behaviour and effects of prescribed fire in masticated fuelbeds. International Journal of Wildland Fire, 20(8), 932-945. https://doi.org/10.1071/WF10110 
Kobziar, L., Moghaddas, J., \& Stephens, S. L. (2007). Tree mortality patterns following prescribed fires in a mixed conifer forest. Canadian Journal of Forest Research, 36(12), 3222-3238. https://doi.org/10.1139/x06-183

Kobziar, L. N., Mcbride, J. R., \& Stephens, S. L. (2009). The efficacy of fire and fuels reduction treatments in a Sierra Nevada pine plantation. International Journal of Wildland Fire, 791-801.

Kreye, J. K., Brewer, N. W., Morgan, P., Varner, J. M., Smith, A. M. S., Hoffman, C. M., \& Ottmar, R. D. (2014). Fire behavior in masticated fuels: A review. Forest Ecology and Management, 314, 193-207. https://doi.org/10.1016/j.foreco.2013.11.035

Kreye, J. K., Varner, J. M., \& Knapp, E. E. (2011). Effects of particle fracturing and moisture content on fire behaviour in masticated fuelbeds burned in a laboratory. International Journal of Wildland Fire, 20(2), 308. https://doi.org/10.1071/wf09126

Kreye, J., \& Varner, J. (2007). Moisture dynamics in masticated fuelbeds: a preliminary analysis. The Fire Environment-Innovations, Management, and Policy; Conference Proceedings, (June), 173186. Retrieved from http://www.firescience.gov/projects/05-2-1-20/project/KreyeVarner2007.pdf

Larson, A. J., \& Churchill, D. J. (2012). Tree spatial patterns in fire-frequent forests of western North America, including mechanisms of pattern formation and implications for designing fuel reduction and restoration treatments. Forest Ecology and Management, 267, 74-92. https://doi.org/10.1016/j.foreco.2011.11.038

Long, J. N., \& Shaw, J. D. (2012). A Density Management Diagram for Even-Aged Sierra Nevada Mixed-Conifer Stands. Western Journal of Applied Forestry, 27(8330), 187-195.

Lyons-Tinsley, C., \& Peterson, D. L. (2012). Surface fuel treatments in young, regenerating stands affect wildfire severity in a mixed conifer forest, eastside Cascade Range, Washington, USA. Forest Ecology and Management, 270, 117-125. https://doi.org/10.1016/j.foreco.2011.04.016

McDonald, P. M., \& Fiddler, G. O. (2010). Twenty-five years of managing vegetation in conifer plantations in northern and central California: results, application, principles, and challenges. Gen. Tech. Rep. PSW-GTR_231. Albany, CA: USDA Forest Service. Retrieved from http://www.srs.fs.usda.gov/pubs/37965

Miller, J. D., Safford, H. D., Crimmins, M., \& Thode, A. E. (2009). Quantitative evidence for increasing forest fire severity in the Sierra Nevada and southern Cascade Mountains, California and Nevada, USA. Ecosystems, 12(1), 16-32. https://doi.org/10.1007/s10021-008-9201-9

Noonan-Wright, E. K., Vaillant, N. M., \& Reiner, A. L. (2014). The effectiveness and limitations of fuel modeling using the fire and fuels extension to the forest vegetation simulator. Forest Science, 60(2), 231-240. https://doi.org/10.5849/forsci.12-062

North, M. P. (2012). Managing Sierra Nevada forests. Gen. Tech. Rep. PSW-GTR-237. Albany, CA, USA: USDA Forest Service. Retrieved from http://www.srs.fs.usda.gov/pubs/40254

North, M. P., Innes, J., \& Zald, H. S. J. (2007). Comparison of thinning and prescribed fire restoration treatments to Sierran mixed-conifer historic conditions. Canadian Journal of Forest Research, 37(2), 331-342. https://doi.org/10.1139/X06-236

North, M. P., Stephens, S. L., Collins, B. M., Agee, J. K., Aplet, G. H., Franklin, J. F., \& Fulé, P. Z. (2015). Reform forest fire management. Science, 349(6254), 1280-1281. https://doi.org/10.1126/science.aab2356

North, M. P., Stevens, J. T., Greene, D. F., Coppoletta, M., Knapp, E. E., Latimer, A. M., ... Wyrsch, P. (2019). Tamm Review: Reforestation for resilience in dry western U.S. forests. Forest Ecology and Management, 432(July 2018), 209-224. https://doi.org/10.1016/j.foreco.2018.09.007

North, M. P., Stine, P. A., O’Hara, K., Zielinski, W. J., Stephens, S. L., Service, F., \& Hara, K. O. (2009). An ecosystem management strategy for Sierran mixed- conifer forests. Gen. Tech. Rep. PSWGTR-220. Albany, CA, USA: USDA Forest Service.

Pawlikowski, N. C., Coppoletta, M., Knapp, E., \& Taylor, A. H. (2019). Spatial dynamics of tree group and gap structure in an old-growth ponderosa pine-California black oak forest burned by repeated wildfires. Forest Ecology and Management, 434(November 2018), 289-302. https://doi.org/10.1016/j.foreco.2018.12.016 
Pellegrini, A. F. A., Anderegg, W. R. L., Paine, C. E. T., Hoffmann, W. A., Kartzinel, T., Rabin, S. S., ... Pacala, S. W. (2017). Convergence of bark investment according to fire and climate structures ecosystem vulnerability to future change. Ecology Letters, 20(3), 307-316. https://doi.org/10.1111/ele.12725

Reiner, A. L., Vaillant, N. M., \& Dailey, S. N. (2012). Mastication and Prescribed Fire Influences on Tree Mortality and Predicted Fire Behavior in Ponderosa Pine. Journal of Applied Forestry, 27(1), 3641.

Reiner, A. L., Vaillant, N. M., Fites-Kaufman, J. A., \& Dailey, S. N. (2009). Mastication and prescribed fire impacts on fuels in a 25-year old ponderosa pine plantation, southern Sierra Nevada. Forest Ecology and Management, 258(11), 2365-2372. https://doi.org/10.1016/j.foreco.2009.07.050

Reinhardt, E. D., \& Crookston, N. L. (2003). Fire and Fuels Extension to the Forest Vegetation Simulator. Gen. Tech. Rep. RMRS-GTR-116. Ogden, UT, USA: USDA Forest Service. Retrieved from http://www.fs.fed.us/rm/pubs/rmrs_gtr116.pdf

RStudio Team. (2018). RStudio: Integrated Development for R. Boston, MA. Retrieved from http://www.rstudio.com/

Safford, H. D., Stevens, J. T., Merriam, K., Meyer, M. D., \& Latimer, A. M. (2012). Fuel treatment effectiveness in California yellow pine and mixed conifer forests. Forest Ecology and Management, 274, 17-28. https://doi.org/10.1016/j.foreco.2012.02.013

Schmidt, D. A., Taylor, A. H., \& Skinner, C. N. (2008). The influence of fuels treatment and landscape arrangement on simulated fire behavior, Southern Cascade range, California. Forest Ecology and Management, 255(8-9), 3170-3184. https://doi.org/10.1016/j.foreco.2008.01.023

Schmidt, L., Hille, M. G., \& Stephens, S. L. (2006). Restoring Northern Sierra Nevada Conifer Forest Composition and Structure with Precribed Fires of Varying Intensities. Fire Ecology, 2(2).

Scott, J. H., \& Burgan, R. E. (2005). Standard fire behavior fuel models: a comprehensive set for use with Rothermel's surface fire spread model. Fort Collins, CO: USDA Forest Service. https://doi.org/10.2737/RMRS-GTR-153

Seli, R. C., Ager, A. A., Crookston, N. L., Finney, M. A., Bahro, B., Agee, J. K., \& McHugh, C. W. (2008). Incorporating Landscape Fuel Treatment Modeling into the Forest Vegetation Simulator. Third Forest Vegetation Simulator Conference, 54, 27-39 234. https://doi.org/10.1016/j.jconhyd.2010.08.009

Shaw, J. D. (2005). Reineke's Stand Density Index: Where Are We and Where Do We Go From Here? Society of American Foresters 2005 National Convention, 1-13.

Smith, F. W. (2009). A manager's guide to Canopy fuels. Fort Collins, CO. Retrieved from https://www.firescience.gov/projects/06-3-3-13/project/06-3-313_a_managers_guide_to_canopy_fuels.pdf

Stage, A. R. (1976). An expression for the effect of aspect, slope, and habitat type on tree growth. Forest Science, 22(4), 457-460.

Stephens, S. L. (1998). Evaluation of the effects of silvicultural and fuels treatments on potential fire behaviour in Sierra Nevada mixed-conifer forests. Forest Ecology and Management, 105(1-3), 21-35. https://doi.org/10.1016/S0378-1127(97)00293-4

Stephens, S. L., Fry, D. L., \& Franco-Vizcaíno, E. (2008). Wildfire and forests in northwestern Mexico: the United States wishes it had similar fire problems. Ecology and Society, 13(2), 10.

Stephens, S. L., \& Moghaddas, J. J. (2005a). Experimental fuel treatment impacts on forest structure, potential fire behavior, and predicted tree mortality in a California mixed conifer forest. Forest Ecology and Management, 215(1-3), 21-36. https://doi.org/10.1016/j.foreco.2005.03.070

Stephens, S. L., \& Moghaddas, J. J. (2005b). Silvicultural and reserve impacts on potential fire behavior and forest conservation: Twenty-five years of experience from Sierra Nevada mixed conifer forests. Biological Conservation, 125(3), 369-379. https://doi.org/10.1016/j.biocon.2005.04.007

Thompson, J. R., Spies, T. A., \& Olsen, K. A. (2011). Canopy damage to conifer plantations within a large mixed-severity wildfire varies with stand age. Forest Ecology and Management, 262(3), 355-360. https://doi.org/10.1016/j.foreco.2011.04.001 
Vaillant, N. M., Fites-Kaufman, J. A., \& Stephens, S. L. (2009). Effectiveness of prescribed fire as a fuel treatment in Californian coniferous forests. International Journal of Wildland Fire, 18(2), 165. https://doi.org/10.1071/wf06065

van Mantgem, P. J., Stephenson, N. L., Knapp, E., Battles, J., \& Keeley, J. E. (2011). Long-term effects of prescribed fire on mixed conifer forest structure in the Sierra Nevada, California. Forest Ecology and Management, 261(6), 989-994. https://doi.org/10.1016/j.foreco.2010.12.013

Weatherspoon, C. P., \& Skinner, C. N. (1995). An assessment of factors associated with damage to tree crowns from the 1987 wildfires in Northern California. Forest Science, 41(3), 430-451.

Welch, K. R., Safford, H. D., \& Young., T. P. (2016). Predicting conifer establishment 5-7 years after wildfire in middle elevation yellow pine and mixed conifer forests of the North American Mediterranean-climate zone. Ecosphere, in press(December). https://doi.org/10.1002/ecs2.1609

Zald, H. S. J., \& Dunn, C. J. (2018). Severe fire weather and intensive forest management increase fire severity in a multi-ownership landscape. Ecological Applications, 28(4), 1068-1080. https://doi.org/10.1002/eap.1710

Zald, H. S. J., Gray, A. N., North, M. P., \& Kern, R. A. (2008). Initial tree regeneration responses to fire and thinning treatments in a Sierra Nevada mixed-conifer forest, USA. Forest Ecology and Management, 256(1-2), 168-179. https://doi.org/10.1016/j.foreco.2008.04.022

Zhang, J., Oliver, W. W., Ritchie, M. W., \& Neal, D. L. (2013). Overstory and understory dynamics in a ponderosa pine plantation vary with stand density in the Sierra Nevada: 40 -year results. Forest Science, 59(6), 670-680. https://doi.org/10.5849/forsci.10-033

Zhang, J., Ritchie, M. W., Maguire, D. A., \& Oliver, W. W. (2013). Thinning ponderosa pine ( Pinus ponderosa ) stands reduces mortality while maintaining stand productivity. Canadian Journal of Forest Research, 43(4), 311-320. https://doi.org/10.1139/cjfr-2012-0411

Zhang, J., Webster, J., Powers, R. F., \& Mills, J. (2008). Reforestation after the Fountain Fire in Northern California: An Untold Success Story. Journal of Forestry, 106(8), 425-430.

Ziegler, J. P., Hoffman, C., Battaglia, M., \& Mell, W. (2017). Spatially explicit measurements of forest structure and fire behavior following restoration treatments in dry forests. Forest Ecology and Management, 386, 1-12. https://doi.org/10.1016/j.foreco.2016.12.002 


\subsection{Figures and Tables}

Table. 1 Regeneration amounts in terms of trees per acre used after incorporating survival rates by species. The no management (a) scenario amounts were delineated by simulation age and TPH (trees per hectare). For treated stands (b) (mastication + prescribed burning, mastication only, thinning only) regen was only implemented after treatments and delineated by fuel treatment and thinning target.

(a)

No management

\begin{tabular}{|c|c|c|c|c|c|c|c|c|}
\hline \multirow[b]{4}{*}{ Species } & \multicolumn{8}{|c|}{ Age } \\
\hline & \multicolumn{3}{|c|}{$0-30$} & \multicolumn{3}{|c|}{$30-60$} & \multicolumn{2}{|c|}{$60-100$} \\
\hline & \multicolumn{8}{|c|}{ Trees per Hectare } \\
\hline & $0-247$ & $247-495$ & $495-990$ & $0-247$ & $247-495$ & $>495$ & $0-247$ & $>247$ \\
\hline PIPO & 3.75 & 1.5 & 0.75 & 6 & 1.5 & 0.75 & 9.75 & 1.5 \\
\hline PILA & 2.7 & 0.9 & 0.9 & 1.8 & 0.9 & 0.9 & 2.7 & 0.9 \\
\hline $\mathrm{ABCO}$ & 2.7 & 1.35 & 0.9 & 4.5 & 1.35 & 0.9 & 7.65 & 1.35 \\
\hline CADE & 3.6 & 2.4 & 1.2 & 6 & 2.4 & 1.2 & 10.2 & 2.4 \\
\hline TOTAL & 12.75 & 6.15 & 3.75 & 18.3 & 6.15 & 3.75 & 30.3 & 6.15 \\
\hline \multirow[t]{2}{*}{ (b) } & \multicolumn{3}{|c|}{ Mastication + Prescribed Burn } & \multicolumn{3}{|c|}{ Mastication only + Thinning only } & & \\
\hline & \multicolumn{6}{|c|}{ Thinning Target } & & \\
\hline Species & 370 SDI & $495 \mathrm{SDI}$ & 618 SDI & 370 SDI & $495 \mathrm{SDI}$ & 618 SDI & & \\
\hline PIPO & 11.25 & 8.1 & 5.4 & 6.25 & 4.5 & 3 & & \\
\hline PILA & 1.75 & 1.4 & 1.05 & 1.5 & 1.2 & 0.9 & & \\
\hline $\mathrm{ABCO}$ & 6 & 4.5 & 3 & 6 & 4.5 & 3 & & \\
\hline CADE & 6 & 4.6 & 3 & 6 & 4.6 & 3 & & \\
\hline TOTAL & 25 & 18.6 & 12.45 & 19.75 & 14.8 & 9.9 & & \\
\hline
\end{tabular}

Table 2. Matrix of treatments used in FVS simulations. SDI = Stand Density Index. Mast = mastication only, Mast + Burn = mastication with burning.

Thinning Target

\begin{tabular}{lllll} 
Fuels Treatment & 370 SDI & 495 SDI & 618 SDI & No Thin \\
\hline Mast. & All Stands & All Stands & All Stands & All Stands \\
Mast. + Burn & All Stands & All Stands & All Stands & All Stands \\
No fuel treatment & All Stands & All Stands & All Stands & All Stands \\
\hline
\end{tabular}


Table 3. Simulated prescribed fire and potential severe fire conditions.

Fuel Moisture (\%)

\begin{tabular}{llllllllll}
\cline { 5 - 9 } Fire & $\begin{array}{l}\text { Windspeed } \\
(\mathrm{kph})\end{array}$ & $\begin{array}{l}\text { Temperature } \\
\left(\mathrm{C}^{0}\right)\end{array}$ & $1 \mathrm{hr}$ & $10 \mathrm{hr}$ & $100 \mathrm{hr}$ & $1000 \mathrm{hr}$ & Duff & $\begin{array}{l}\text { Live } \\
\text { Woody }\end{array}$ & $\begin{array}{l}\text { Live } \\
\text { Herb }\end{array}$ \\
\hline $\begin{array}{l}\text { Prescribed } \\
\text { 97\% Fire }\end{array}$ & 4.8 & 10 & 12 & 12 & 14 & 25 & 150 & 150 & 150 \\
Weather & 35.4 & 31 & 2.7 & 3.1 & 5 & 6.4 & 2.7 & 69.9 & 20.9 \\
\hline
\end{tabular}

Table 4. Description of fuel models from Scott and Burgan (2005) used in this study.

\begin{tabular}{|c|c|c|c|c|c|c|}
\hline \multirow[b]{2}{*}{ Model } & \multirow[b]{2}{*}{ Use } & \multirow[b]{2}{*}{ Description } & \multicolumn{3}{|c|}{ Fuel Load $\left(\mathrm{kgm}^{-2}\right)$} & \multirow[b]{2}{*}{$\begin{array}{l}\text { Fuel bed } \\
\text { depth }(\mathrm{m})\end{array}$} \\
\hline & & & $1 \mathrm{hr}$ & $10 \mathrm{hr}$ & $100 \mathrm{hr}$ & \\
\hline SB1 & $\begin{array}{l}\text { Masticated fuel beds in plots with original } \\
\text { TPH <1235; Masticated fuel beds following a } \\
\text { prescribed fire }\end{array}$ & Low load, activity fuel & 0.337 & 0.674 & 2.466 & 0.33 \\
\hline SB2 & $\begin{array}{l}\text { Masticated fuel beds in plots with original } \\
\text { TPH >1235 }\end{array}$ & $\begin{array}{l}\text { Moderate load, activity fuel or } \\
\text { low load, blowdown }\end{array}$ & 1.011 & 0.952 & 0.898 & 0.33 \\
\hline TL1 & Post prescribed fire & Low load, compact conifer liter & 0.225 & 0.493 & 0.806 & 0.066 \\
\hline TL3 & $\begin{array}{l}75 \% \text { of low density non-PCT and NRG strands } \\
\text { from start to cycle } 4 \text { or SDI } 865 \text { (no fuel } \\
\text { management) }\end{array}$ & Moderate load, conifer litter & 0.112 & 0.493 & 0.63 & 0.099 \\
\hline TL4 & $\begin{array}{l}75 \% \text { of PCT stands from start to cycle } 3 \text { or } \\
\text { SDI } 865 \text { (no fuel management) }\end{array}$ & Small downed logs & 0.112 & 0.337 & 0.942 & 0.132 \\
\hline GS2 & $\begin{array}{l}25 \% \text { of PCT and low density non-PCT and } \\
\text { NRG stands (no fuel management) }\end{array}$ & $\begin{array}{l}\text { Moderate load, dry climate } \\
\text { grass-shrub }\end{array}$ & 0.112 & 0.112 & 0 & 0.495 \\
\hline TL5 & $\begin{array}{l}75 \% \text { of PCT and low density non-PCT and } \\
\text { NRG stands from cycle } 4 \text { or } 865 \text { SDI to end } \\
\text { (no fuel management) }\end{array}$ & High load, conifer litter & 0.259 & 0.561 & 0.986 & 0.198 \\
\hline TL8 & $\begin{array}{l}\text { High density non-PCT and NRG stands from } \\
\text { cycle } 3 \text { or } 988 \text { SDI to end (no fuel } \\
\text { management) }\end{array}$ & Long-Needle litter & 1.3 & 0.312 & 0.249 & 0.099 \\
\hline TU4 & $\begin{array}{l}\text { High density non-PCT and NRG stands from } \\
\text { start to cycle } 3 \text { or } 988 \text { SDI (no fuel } \\
\text { management) }\end{array}$ & Dwarf conifer with understory & 1.011 & 0 & 0 & 0.165 \\
\hline
\end{tabular}


Table 5. P-values from three-way ANOVA. Fuels $=$ fuel treatment, thin $=$ thinning target, Trt $=$ original management. $*=$ significance at the 0.05 level

\begin{tabular}{|c|c|c|c|c|c|c|c|}
\hline Variable & fuels & thin & Trt & fuels*thin & $\begin{array}{l}\text { fuels*Tr } \\
\mathrm{t}\end{array}$ & $\begin{array}{l}\text { thin } * \operatorname{Tr} \\
\mathrm{t}\end{array}$ & $\begin{array}{l}\text { fuels*t } \\
\text { hin*trt }\end{array}$ \\
\hline $\begin{array}{l}\text { Final BA }\left(\mathrm{m}^{\wedge} 2^{*}\right. \\
\left.h e c^{\wedge}-1\right)\end{array}$ & $<0.0001 *$ & $<0.0001 *$ & 0.873 & $<0.0001 *$ & 0.116 & 0.871 & 0.9999 \\
\hline Final QMD (cm) & 0.3701 & $<0.0001 *$ & $<0.0001^{*}$ & $0.0373 *$ & 0.9892 & 0.7782 & 1 \\
\hline $\begin{array}{l}\text { Age Surface fire } \\
\text { begins }\end{array}$ & $<0.0001^{*}$ & $0.0005^{*}$ & $<0.0001^{*}$ & $0.0213^{*}$ & 0.3053 & 0.9814 & 0.9999 \\
\hline $\begin{array}{l}\text { Age when less than } \\
25 \% \text { BA mortality } \\
\text { begins }\end{array}$ & $<0.0001 *$ & $0.0175^{*}$ & $<0.0001 *$ & 0.4502 & 0.6775 & 0.9952 & 0.995 \\
\hline $\begin{array}{l}\text { Age when canopy } \\
\text { base height exceeds } \\
\text { flame length }\end{array}$ & $<0.0001 *$ & $0.0016^{*}$ & $<0.0001 *$ & 0.0513 & 0.1345 & 0.9894 & 1 \\
\hline $\begin{array}{l}\text { Final Crowning } \\
\text { Index (kmph) }\end{array}$ & $<0.0001 *$ & $<0.0001 *$ & $0.0003^{*}$ & $0.0073^{*}$ & 0.1083 & 0.1832 & 0.9999 \\
\hline
\end{tabular}

Table 6. Basal area $\left(\mathrm{m}^{2} \mathrm{ha}^{-1}\right)$ at end of simulation by thinning target and fuel treatment (Mast = mastication only, $\mathrm{MB}=$ mastication with burning, $\mathrm{No}=$ No fuel treatment), values are averaged across all original management ("Total"). Different letters in the "Total" column indicate significant differences $(\mathrm{p}<0.05)$ between fuel treatments and different letters in the "Total" row indicate significant differences $(\mathrm{p}<0.05)$ between thinning targets. SDI $=$ stand density index.

\begin{tabular}{|c|c|c|c|c|c|}
\hline \multirow[b]{2}{*}{ Fuel Treatment } & \multicolumn{4}{|c|}{ Thinning Target } & \multirow[b]{2}{*}{ Total } \\
\hline & 370SDI & 495SDI & 618SDI & No Thin & \\
\hline Mast & 33.7 & 43.5 & 52.5 & 58.0 & $46.9 \mathrm{a}$ \\
\hline Mast + Burn & 31.7 & 39.0 & 43.3 & 44.7 & $39.7 b$ \\
\hline No Fuel & 33.6 & 43.5 & 52.6 & 58.1 & $46.9 \mathrm{a}$ \\
\hline Total & $33.0 \mathrm{a}$ & $42.0 \mathrm{~b}$ & $49.5 \mathrm{c}$ & $53.6 \mathrm{~d}$ & 44.5 \\
\hline
\end{tabular}


Table 7. QMD $(\mathrm{cm})$ at end of simulation by thinning target and fuel treatment (a) (Mast = mastication only, $\mathrm{MB}=$ mastication with burning, $\mathrm{No}=$ No fuel treatment $)$ and original management $(\mathrm{b})(\mathrm{NRG}=$ natural regenerating stands, $\mathrm{PCT}=$ plantations with pre-commercial thinning, non-PCT $=$ plantations without pre-commercial thinning). SDI = stand density index.

\begin{tabular}{|c|c|c|c|c|c|c|c|}
\hline & & & \multicolumn{4}{|c|}{ Thinning Target } & \multirow[b]{2}{*}{ Total } \\
\hline & & & 370 SDI & 495SDI & 618SDI & No Thin & \\
\hline \multirow[t]{3}{*}{ a) } & Fuels & Mast & 86.3 & 79.6 & 74.3 & 65.5 & 76.4 \\
\hline & & $\begin{array}{l}\text { Mast + } \\
\text { Burn }\end{array}$ & 83.0 & 78.1 & 75.1 & 73.6 & 77.5 \\
\hline & & No Fuel & 86.0 & 79.5 & 73.6 & 61.3 & 75.1 \\
\hline \multirow[t]{4}{*}{ b) } & Trt & NRG & 93.9 & 85.8 & 79.5 & 70.9 & 82.5 \\
\hline & & PCT & 81.3 & 76.3 & 72.4 & 66.1 & 74.0 \\
\hline & & $\begin{array}{l}\text { Non- } \\
\text { PCT }\end{array}$ & 82.0 & 76.5 & 72 & 63.8 & 73.6 \\
\hline & \multicolumn{2}{|c|}{ Overall } & 85.1 & 79.1 & 74.3 & 66.8 & 76.3 \\
\hline
\end{tabular}

Table 8. Mortality (\%) from prescribed fires by original management (a) (Trt: NRG = natural regenerating stands, $\mathrm{PCT}=$ plantations with pre-commercial thinning, non-PCT $=$ plantations without precommercial thinning), thinning target (b), and year of fire. Different letters in each column within Trt or Thinning target indicate a significant $(\mathrm{p}<0.05)$ difference in mortality. SDI $=$ stand density index.

\begin{tabular}{|c|c|c|c|c|c|c|c|}
\hline & & & \multicolumn{5}{|c|}{ Year of Prescribed Fire } \\
\hline & & & 2027 & 2037 & 2057 & 2077 & 2097 \\
\hline & Trt & $\mathrm{NRG}$ & $60 a$ & $36.3 \mathrm{a}$ & $12.9 \mathrm{a}$ & $6.4 \mathrm{a}$ & $4.1 \mathrm{a}$ \\
\hline & & $\mathrm{TH}$ & $43.2 b$ & $24.6 b$ & $10.8 \mathrm{ab}$ & $6.1 \mathrm{a}$ & $4.1 \mathrm{a}$ \\
\hline & & UTH & $52.5 \mathrm{c}$ & $35.1 \mathrm{a}$ & $15.3 b$ & $7.0 \mathrm{a}$ & $4.2 \mathrm{a}$ \\
\hline \multirow[t]{5}{*}{ b) } & Thinning & 370SDI & $50.1 \mathrm{a}$ & $30.6 a$ & $11.8 \mathrm{a}$ & $5.6 \mathrm{a}$ & $3.4 \mathrm{a}$ \\
\hline & Target & 495SDI & $50.7 \mathrm{a}$ & $31.0 \mathrm{a}$ & $12.8 \mathrm{a}$ & $6.3 \mathrm{a}$ & $3.9 \mathrm{ab}$ \\
\hline & & 618SDI & $50.9 \mathrm{a}$ & $31.0 \mathrm{a}$ & $13.1 \mathrm{a}$ & $6.8 \mathrm{a}$ & $4.4 b$ \\
\hline & & No Thin & $50.9 \mathrm{a}$ & $31.0 \mathrm{a}$ & $13.2 \mathrm{a}$ & $7.1 \mathrm{a}$ & $4.8 b$ \\
\hline & & Total (all stands) & $32.9-64.3$ & $19.1-44.5$ & $6.4-21.5$ & $3.8-11.1$ & $2.3-7.3$ \\
\hline
\end{tabular}


Table 9. Surface and total flame lengths $(\mathrm{m})$ and spread rate $(\mathrm{m} / \mathrm{min})$ by fuel treatments $($ Mast $=$ mastication only, $\mathrm{MB}=$ mastication with burning, No Fuel $=$ No fuel treatment). Different letters in rows indicate a difference in flame length or spread rate between fuel treatments.

\begin{tabular}{llllll} 
& & \multicolumn{2}{c}{ Fuel Treatment } & \\
\cline { 3 - 5 } & & Mast & MB & No Fuel & Total \\
\hline Flame length $(\mathrm{m})$ & Surface & $1.3 \mathrm{a}$ & $0.6 \mathrm{~b}$ & $1.4 \mathrm{c}$ & 1.1 \\
& Total & $3.2 \mathrm{a}$ & $0.9 \mathrm{~b}$ & $3.9 \mathrm{a}$ & 2.7 \\
\hline $\begin{array}{l}\text { Spread rate } \\
(\mathrm{m} / \mathrm{min})\end{array}$ & Surface & $3.8 \mathrm{a}$ & $1.8 \mathrm{~b}$ & $4.4 \mathrm{c}$ & 3.3 \\
& Total & $8.6 \mathrm{a}$ & $3.3 \mathrm{~b}$ & $10.0 \mathrm{a}$ & 7.3 \\
\hline
\end{tabular}




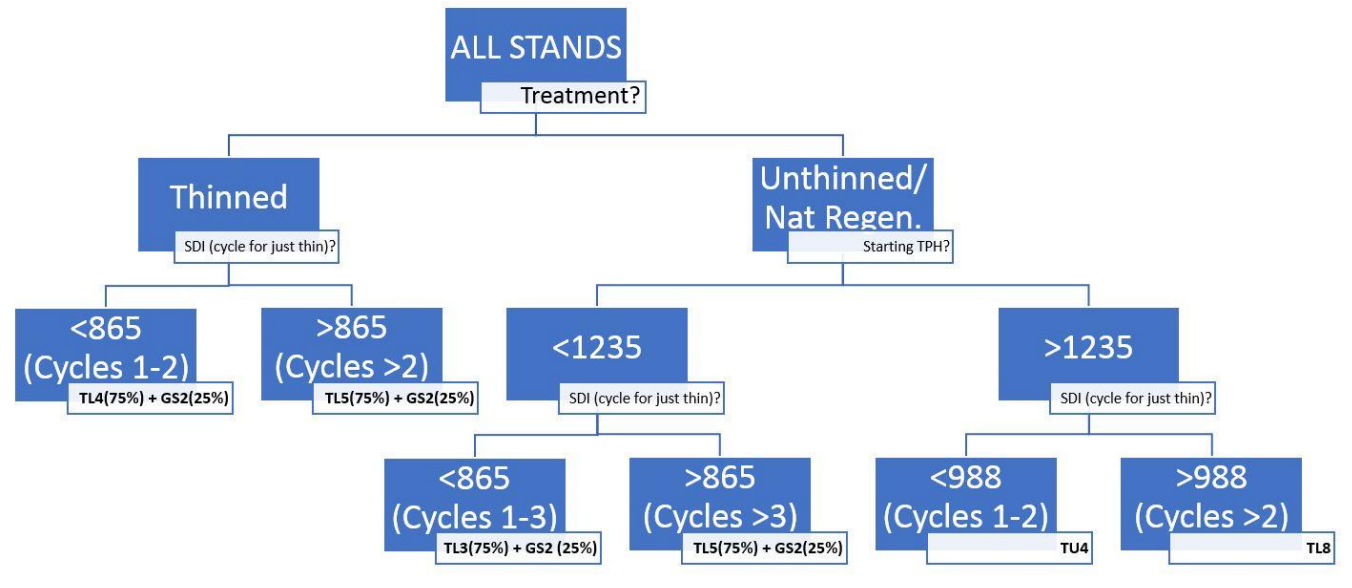

Figure 1. Decision tree showing fuel model used in unmanaged simulations, only overstory thinning simulations, and initial conditions. SDI $=$ stand density index; $\mathrm{TPH}=$ trees per hectare; see Table 4 or Scott and Burgan (2005) for full description of fuel model names in final white boxes.

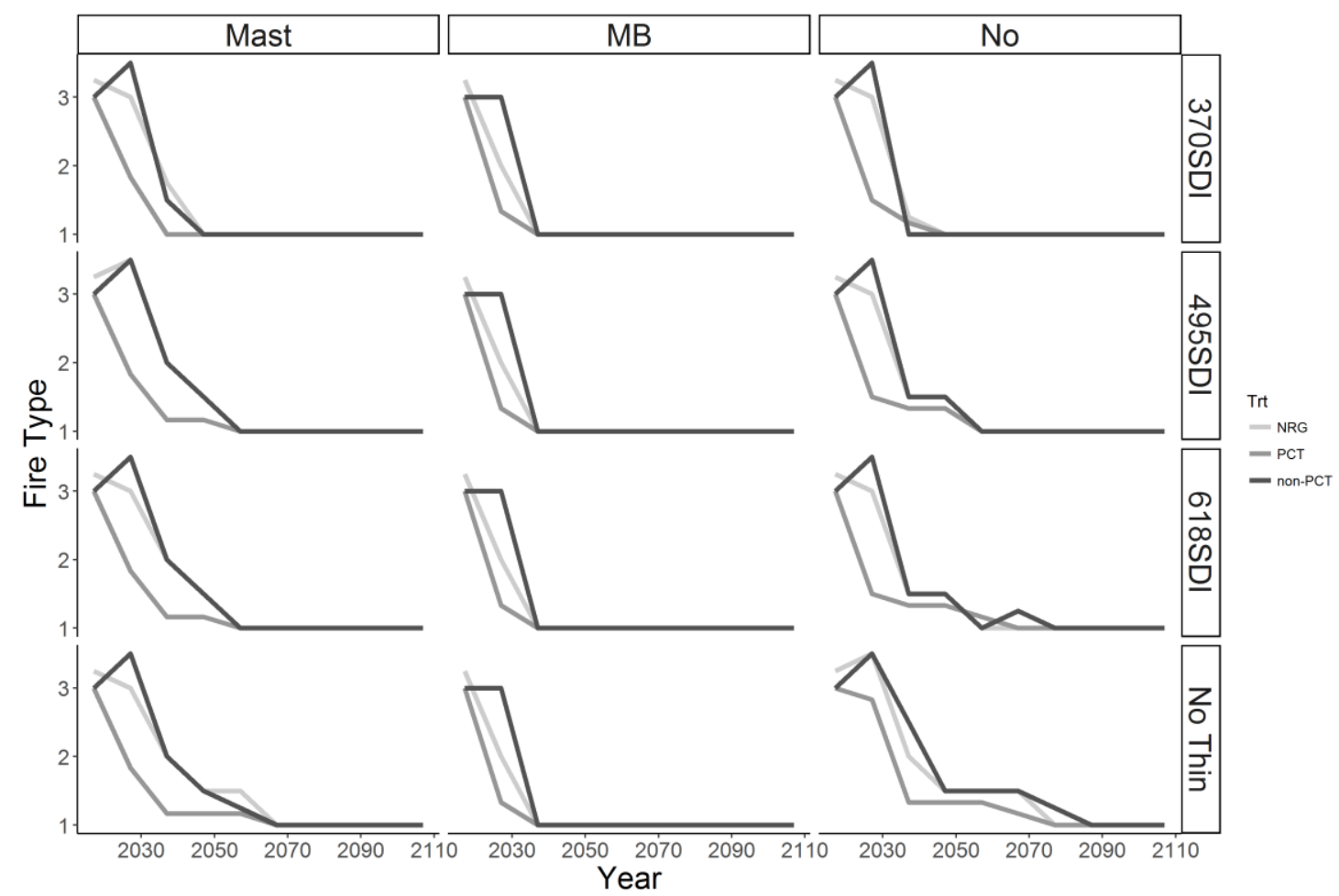

Figure 2. Potential fire type over time by fuel treatment (Mast $=$ mastication only, $\mathrm{MB}=$ mastication with burning, $\mathrm{No}=$ No fuel treatment), thinning target, and original management (Trt: NRG = natural regenerating stands, $\mathrm{PCT}=$ plantations with pre-commercial thinning, non-PCT = plantations without pre-commercial thinning). Y Axis: $4=$ Active crown five, $3=$ passive crown fire, $2=$ conditional crown fire, 1 = surface fire. 


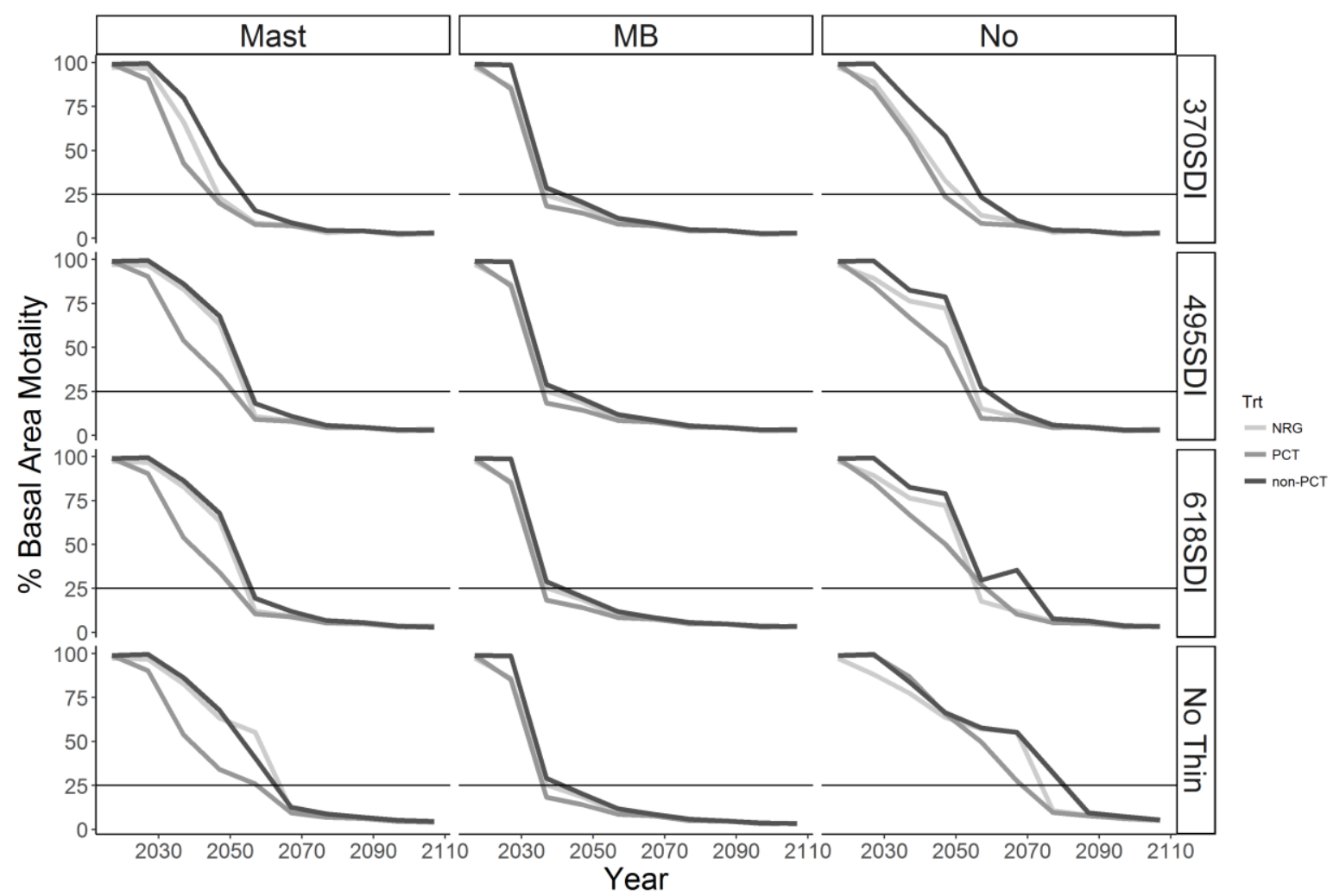

Figure 3. \% basal area mortality from potential fires over time by fuel treatment (Mast $=$ mastication only, $\mathrm{MB}=$ mastication with burning, No = No fuel treatment), thinning target, and original management $($ Trt: NRG $=$ natural regenerating stands, PCT $=$ plantations with pre-commercial thinning, non-PCT $=$ plantations without pre-commercial thinning). 


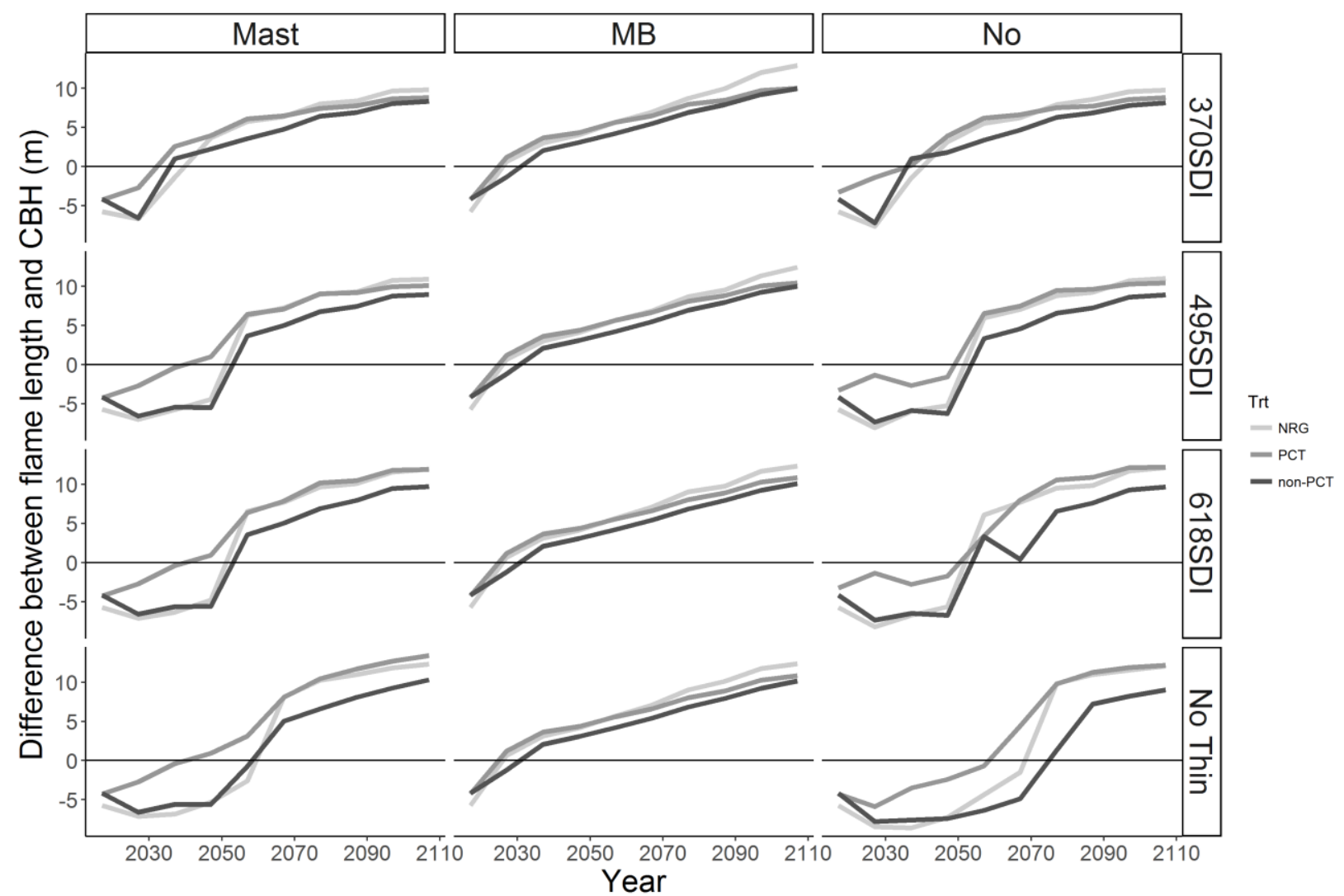

Figure 4. Canopy base height minus total flame length from potential fires over time by fuel treatment (Mast = mastication only, $\mathrm{MB}=$ mastication with burning, No $=$ No fuel treatment), thinning target, and original management $($ Trt: $\mathrm{NRG}=$ natural regenerating stands, PCT $=$ plantations with precommercial thinning, non-PCT = plantations without pre-commercial thinning). 

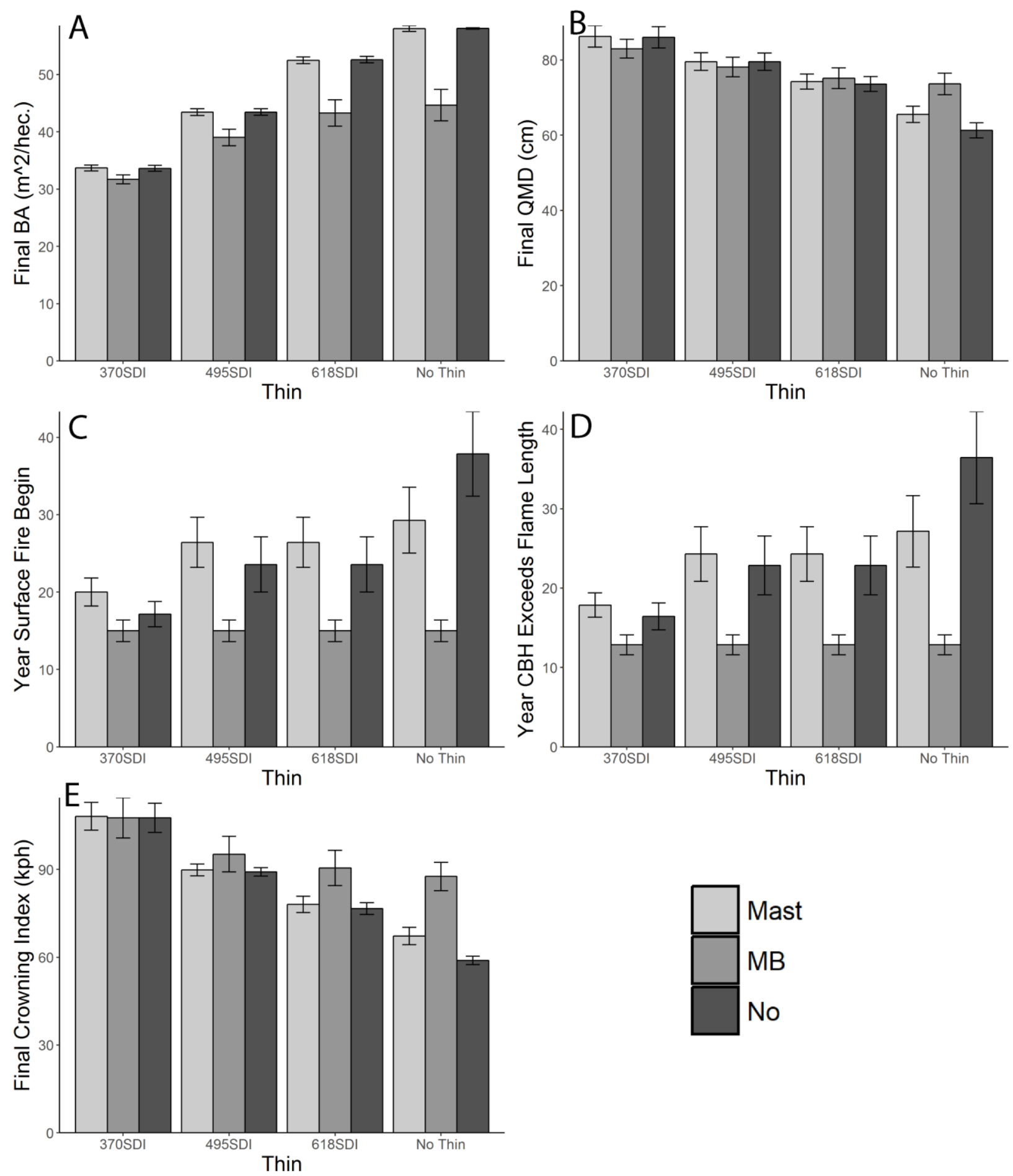

Figure 5. Interaction of fuel treatment (Mast = mastication only, $\mathrm{MB}=$ mastication with burning, No $=$ No fuel treatment $)$ and thinning target for A) basal area $\left.\left.\left(\mathrm{m}^{2} \mathrm{ha}^{-1}\right), \mathrm{B}\right) \mathrm{QMD}(\mathrm{cm}), \mathrm{C}\right)$ age when surface fire begins, D) age CBH exceeds flame length, and E) final crowning index (kph). Error bars are +/1standard error. 

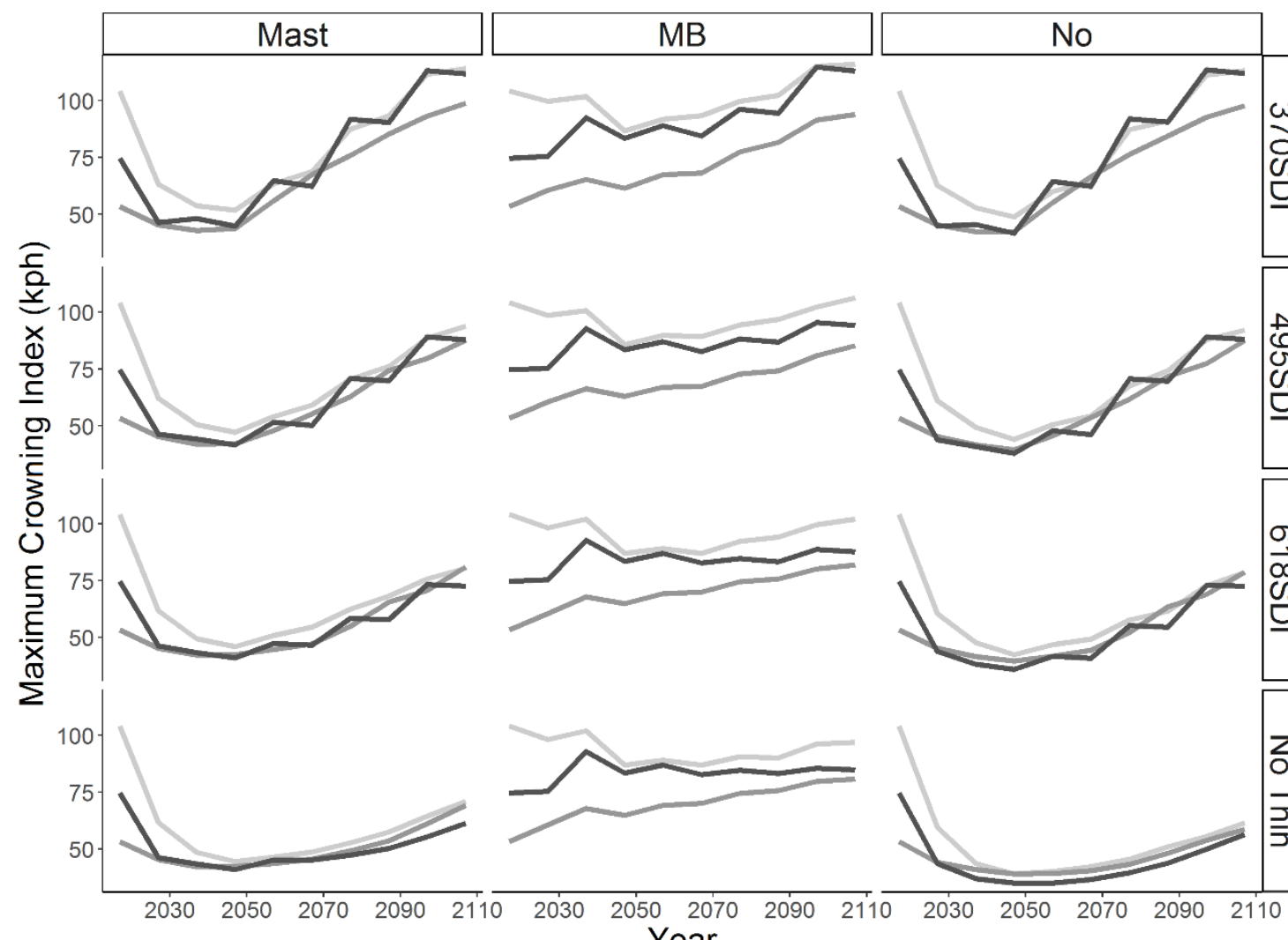

$\stackrel{\text { Trt }}{=}$ NRG

- PCT
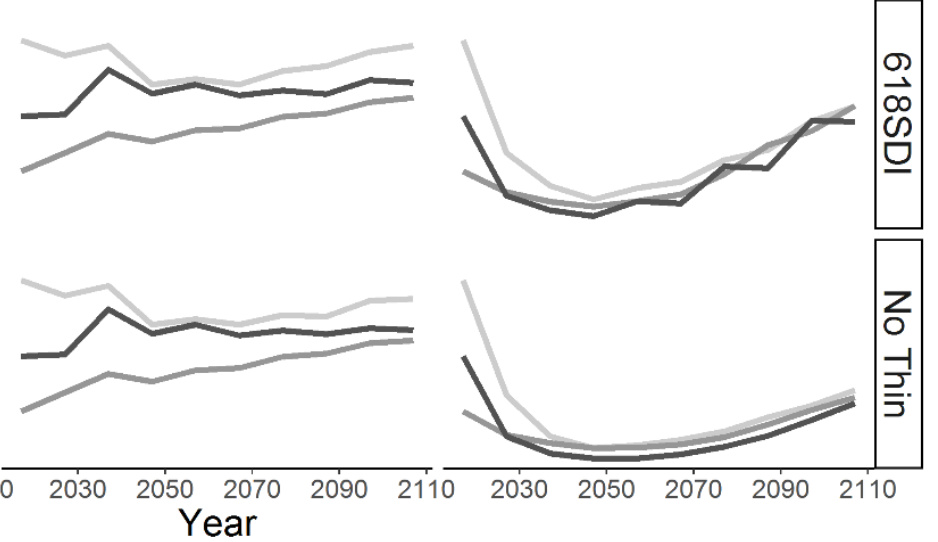

Figure 6. Crowning index from potential fires over time by fuel treatment (Mast = mastication only, $\mathrm{MB}=$ mastication with burning, No $=$ No fuel treatment), thinning target, and original management (Trt: NRG = natural regenerating stands, $\mathrm{PCT}=$ plantations with pre-commercial thinning, non-PCT $=$ plantations without pre-commercial thinning). 


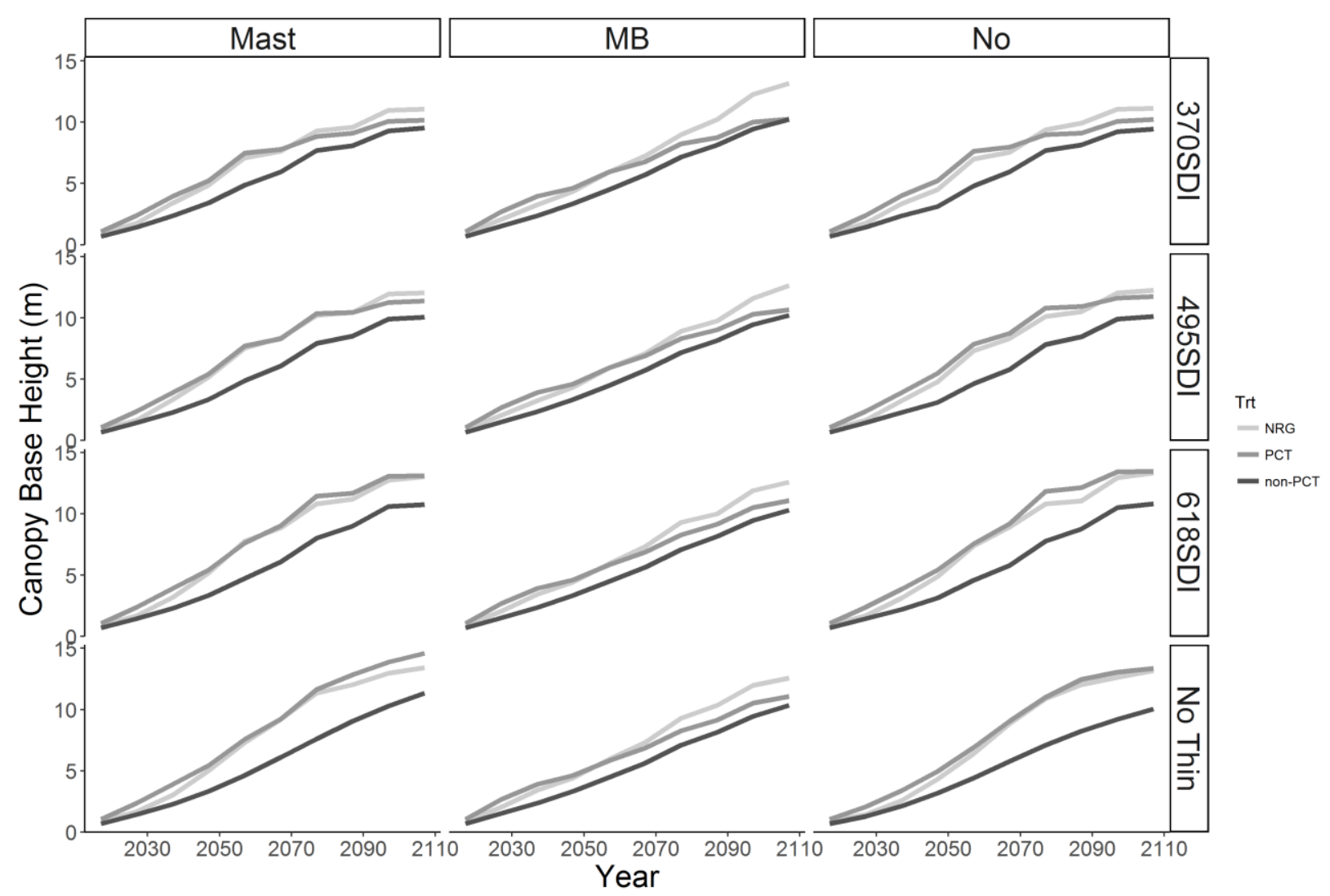

Figure 7. Canopy base height over time by fuel treatment (Mast = mastication only, $\mathrm{MB}=$ mastication with burning, No $=$ No fuel treatment), thinning target, and original management (Trt: NRG = natural regenerating stands, $\mathrm{PCT}=$ plantations with pre-commercial thinning, non-PCT $=$ plantations without pre-commercial thinning). 


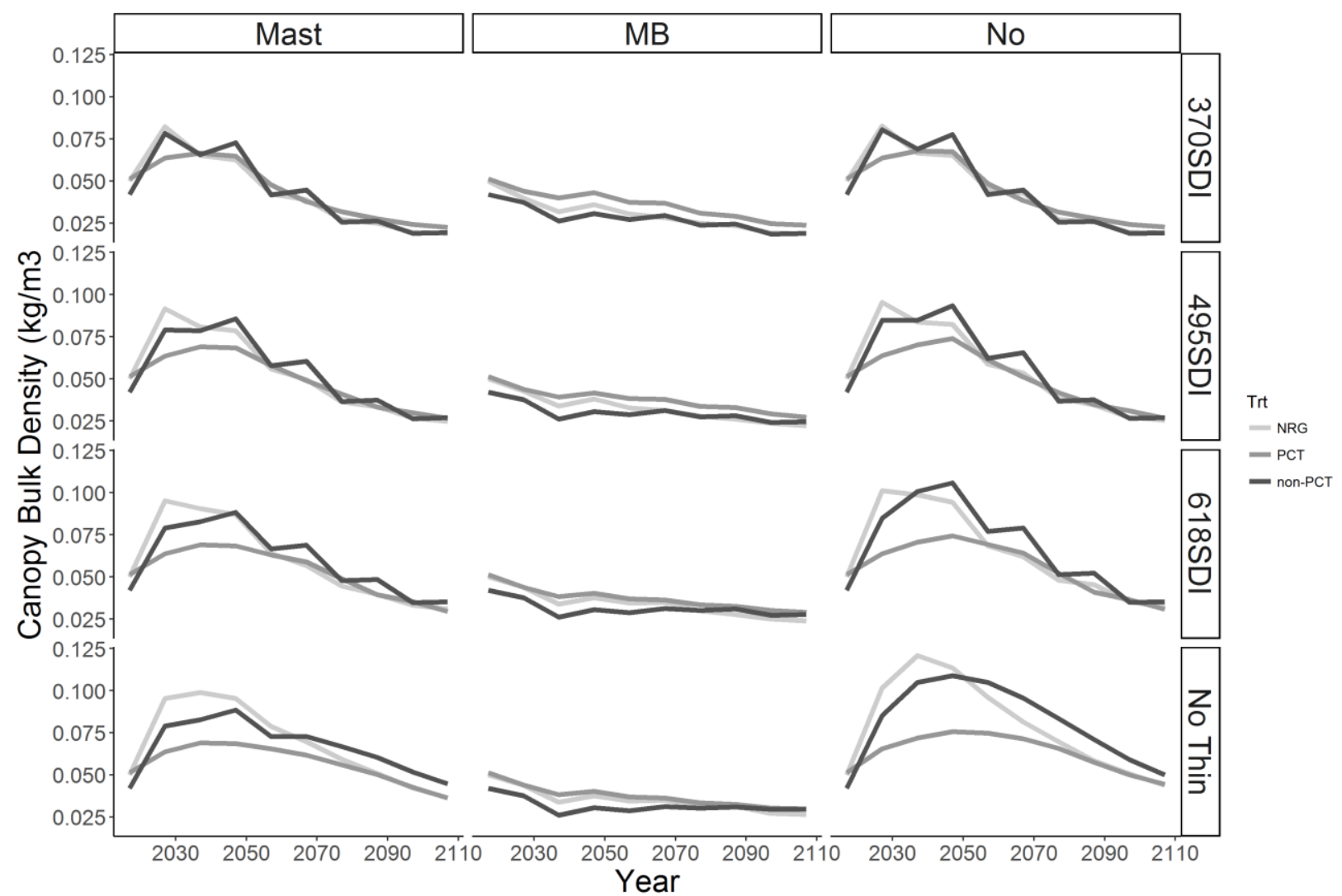

Figure 8. Canopy bulk density over time by fuel treatment (Mast $=$ mastication only, $\mathrm{MB}=$ mastication with burning, No $=$ No fuel treatment), thinning target, and original management (Trt: NRG = natural regenerating stands, $\mathrm{PCT}=$ plantations with pre-commercial thinning, non-PCT $=$ plantations without pre-commercial thinning). 


\section{Chapter 4: Conclusions}

The effects of past management on mixed conifer forests in the Sierra Nevada has changed how they regenerate after fires and therefore changed how to keep them healthy and resilient to crown fires. In my thesis I compared current growth and ecology of young, post fire plantations as well as naturally regenerating stands and then forecasted their growth and potential fire behavior into the future under different management scenarios.

When comparing growth between the two planting arrangements in the young plantations, differences were minimal. However, the clustered plantations grew more before thinning than the evenly spaced plantations, suggesting that cluster plantations can provide a slight facilitative effect in young stands. The thinned plantations had larger trees than the unthinned and natural regenerating stands, but the confounding effect of thinning and elevation made comparing between thinned and unthinned plantations difficult to interpret. However, there was an effect of thinning found when comparing the BAI of the thinned plantations before and after thinning. The effects of shrub growth were seen in multiple variables including tree density and diameter growth, which highlights a major difficulty post fire that mixed conifer plantations face in the Sierra Nevada Mountains.

When comparing fire behavior and growth across stands and simulations, several patterns emerged. In all simulations I found a general pattern of decreasing fire intensity over time, due to increasing canopy base heights and decreasing canopy bulk density. The amount of time before low severity surface fire was reached could be altered with fuel treatments and overstory thinning. I found mastication with burning to be the most effective fuel treatment for reducing fire risk and increasing growth quickly by drastically reducing surface fuels and thus flame length and stand density. I found minimal difference between the mastication treatments, except in surface fire behavior which influenced mortality. Overstory thinning mainly affected canopy bulk density, so its effects were mostly seen by reducing a fire's ability to spread through the canopy. The thinning treatments from below helped reduce ladder fuels when there were not any additional surface fuel treatment. 
My research highlighted how different stressors like planting arrangement, density, shrubs, and light can affect young plantation growth and how silvicultrual treatments interact with growth and development over time to affect fire behavior. This is one of the first studies to compare clustered and evenly spaced plantations in the Sierra Nevada Mountains as well as forecasting post fire plantations' interactions with silvicultrual treatments and fire behavior into the future. There are still many gaps in the knowledge when it comes to interactive effects of cluster plantations with inter-tree facilitation, drought, thinning, and site characteristics. There is also a need to understand how fire behavior in even aged plantation differs from the natural uneven aged stand development usually found in these forests. My study demonstrates the importance of managing post fire plantations closely so shrubs, canopy, density, and surface fuels are controlled to keep them growing productively and resilient to stand replacing crown fires. 